\author{
UNIVERSIDADE DE SÃO PAULO \\ INSTITUTO DE FÍSICA, INSTITUTO DE QUÍMICA, \\ INSTITUTO DE BIOCIÊNCIAS E FACULDADE DE EDUCAÇÃO
}

ÉRICA DE OLIVEIRA

Multiculturalismo e Ensino de Ciências na Educação Básica:

Desafios e potencialidades da astronomia cultural 


\title{
ÉRICA DE OLIVEIRA
}

\section{Multiculturalismo e Ensino de Ciências na Educação Básica: Desafios e potencialidades da astronomia cultural}

\author{
Versão Corrigida
}

Orientadora: Prof ${ }^{\mathrm{a}}$. Drª ${ }^{\mathrm{a}}$. Cristina Leite

Dissertação apresentada aos Institutos de Física, de Química, de Biociências e à Faculdade de Educação da Universidade de São Paulo, como um dos requisitos à obtenção do título de Mestre em Ensino de Ciências.

Programa de Pós-Graduação Interunidades em Ensino de Ciências

Área de Concentração: Ensino de Física

Banca examinadora:

Prof ${ }^{a}$. Drà . Cristina Leite (IFUSP-Orientadora)

Profa. Drª. Flávia Cristina de Mello (UESC)

Prof. Dr. Gustavo Isaac Killner (IFSP)

\section{São Paulo}


Autorizo a reprodução e divulgação total ou parcial deste trabalho, por qualquer meio convencional ou eletrônico, para fins de estudo e de pesquisa, desde que citada a fonte.

\section{FICHA CATALOGRÁFICA \\ Preparada pelo Serviço de Biblioteca e Informação do Instituto de Física da Universidade de São Paulo}

Oliveira, Érica de

Multiculturalismo e ensino de ciências na educação básica: desafios e potencialidades da astronomia cultural. São Paulo, 2020.

Dissertação (Mestrado) - Universidade de São Paulo. Faculdade de Educação, Instituto de Física, Instituto de Química e Instituto de Biociências.

Orientador: Profa. Dra. Cristina Leite

Área de Concentração: Ensino de Física

Unitermos: 1. Física - Estudo e ensino; 2. Astronomia - Estudo e ensino; 3. Ensino de física; 4. Multiculturalismo; 5. Livro didático. 
Aos meus pais,

À Marina,

Ao Vinicius,

Por sempre me acolherem com amor, coragem e esperança.

Essa conquista também é de vocês. 


\section{AGRADECIMENTOS}

À Deus, pela vida, pela oportunidade de progresso e evolução.

Aos meus pais, que sempre me apoiaram em todas as minhas escolhas e que me acolheram fraternalmente nos momentos difíceis e de desespero, pela compressão e carinho de todas as horas. Por fim, obrigada pelo amor incondicional de sempre.

À minha irmã, Marina, pelo companheirismo diário, pela compreensão, por dividir essa trajetória comigo e por sempre me ouvir. Obrigada também pelos ajustes neste trabalho, pela paciência e por sempre me dar ânimo quando eu já estava no desespero. Mari, obrigada por ser a melhor companhia!

Ao Vinicius, pelo apoio e torcida de sempre, durante todo esse processo. Por sempre me tranquilizar com seu amor e afeto, por me dar o ombro amigo e ser o meu companheiro de todas as horas. Muito obrigada!!

À minha orientadora Cristina Leite, por acreditar em mim desde a graduação. Por ser a primeira professora a me acolher nesse instituto quando achei que tudo estava perdido. Obrigada Cris, pelos conselhos de sempre, pela paciência, por ser tão atenciosa e empenhada neste trabalho junto comigo e por partilhar todas as emoções durante esse processo.

Ao professor Ivã Gurgel, que sempre me inspirou com sua paciência e dedicação. Por ter me mostrado caminhos na licenciatura que me fizeram decidir por continuar na graduação e escolhido a carreira acadêmica.

Aos meus amigos e amigas, meus irmãos e irmãs de alma, sem vocês seria impossível essa pesquisa: À Larissa, companheira das batalhas da vida! Obrigada pela paciência e pelos conselhos amorosos e edificantes. Você faz parte das minhas conquistas; ao Guilherme, pelas infinitas conversas e reflexões sobre a vida, pela paciência infinita e pela ajuda de sempre; à Rachel, por dividir todas as minhas alegrias e angústias na mesa ao lado, pelos cafés de cada dia e por tudo e mais um 
pouco; ao Fábio, por ser a inspiração da prática pedagógica e pelas conversas freireanas; à Camila, por sempre me fazer acreditar nesse trabalho, pelas palavras de consolo e coragem; à Marta, pelo companheirismo de pesquisa e de infinitas reflexões matutinas que muito me inspiram.

Nesse sentido, agradeço à Fernanda, Lucas, Rodolpho, Márcia, Gleice, Thais, Matheus e Ihanna, pela parceria e torcida.

Aos meus familiares todos, pelo apoio e leveza nesse processo.

Às crianças que me são mais próximas: Leonardo, Caio, Laura, Kadu, Nicolas e Mateus! Vocês são minha fonte de esperança e alegria.

Ao grupo da Pampédia que sempre me acolheram neste processo!

Aos professores do corredor de ensino, que tanto me apoiaram: Valéria, André, Maria Regina e Cristiano.

Aos parceiros de corredor: Renata e Alessandro, pelo apoio e torcida.

À CAPES pelo apoio financeiro. 


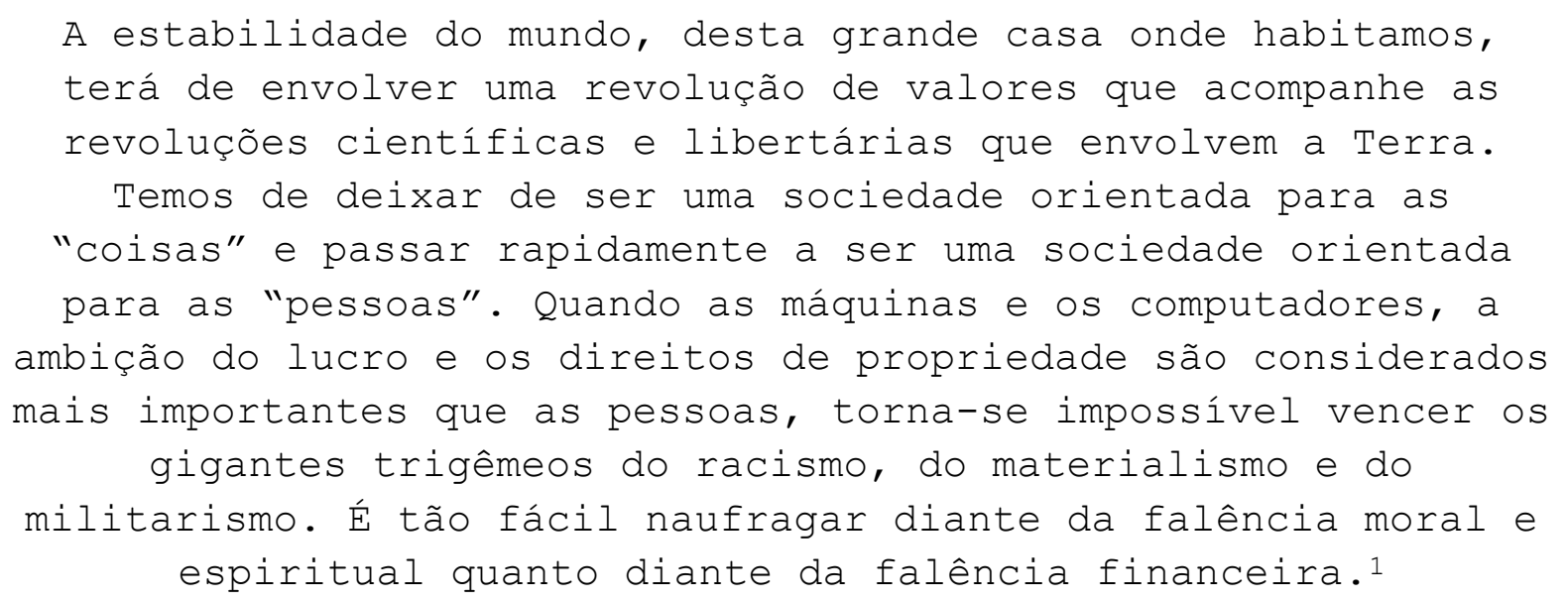

\section{Martin Luther King Jr.}

\footnotetext{
${ }^{1}$ Versão traduzida por Bell Hooks (2017), retirada do original Where do we go from here? Chaos ou Community de Martin Luther King Jr ( 1968, p.196). O original encontra-se abaixo: "The stability of the large world house which is ours will involve a revolution of values to accompany the scientific and freedom revolutions engulfing the earth. We must rapidly begin the shift from a "thing"-oriented society to a "person"-oriented society. When machines and computers, profit motives and property rights are considered more important than people, the giant triplets of racism, materialism and militarism are incapable of being conquered. A civilization can flounder as readily in the face of moral and spiritual bankruptcy as it can through financial bankruptcy."
} 


\section{RESUMO}

OLIVEIRA, É. Multiculturalismo e Ensino de Ciências na Educação Básica: Desafios e potencialidades da astronomia cultural. 2020. Dissertação (Mestrado) - Instituto de Física, Instituto de Química, Instituto de Biociências e Faculdade de Educação, Universidade de São Paulo, São Paulo, 2020.

A escola, espaço construído através de processos históricos, sociais e culturais é palco de múltiplas manifestações culturais e de cruzamento entre elas, em que 0 respeito e a tolerância devem estar presentes, garantindo àqueles que a frequentam, um intercâmbio intercultural democrático. O estudo da Astronomia cultural é um caminho para se levar para o Ensino de Ciências e de Física temáticas multiculturais que valorizem as diversas epistemologias acerca do céu. A medida legislativa no que se refere à Lei Federal 11.645/08 é de grande importância para que haja a presença destes temas por todo o currículo. Para entender como a Astronomia cultural chega até a sala de aula e a forma de como vem sendo abordada nos contextos acadêmicos, foram analisados com base na perspectiva da análise de conteúdo, as pesquisas da área e livros didáticos aprovados no PNLD de física e ciências, totalizando 84 livros. A análise de 31 trabalhos de pesquisa da área, acarretaram na formação de quatro categorias que se mantiveram em sua natureza de outros trabalhos da área. Dentre elas, a de maior número de trabalhos encontrados é a que agrupa as propostas de ensino na educação formal. Porém, ainda que o maior número corresponda a propostas que chegam à escola, algumas considerações são: o aumento em uma década não é significativo; as propostas não se aprofundam nas temáticas; o tamanho dos trabalhos não dá conta de mensurar as propostas como um todo. $\mathrm{Na}$ análise dos LD, foi possível contar com duas grandes dimensões de análise "Monocultural" e "Menos valorizados socialmente". É possível evidenciar que neste tipo de material, a maioria dos livros assume uma abordagem multiculturalista de viés assimilacionista e diferencialista, que tem a postura de tentar integrar os grupos menos visibilizados à cultura hegemônica ou reconhece as diferenças particulares de cada grupo, no entanto, são livros que se afastam da proposta de multiculturalismo intercultural, com uma postura crítica e de diálogo entre os diferentes grupos culturais. Almejamos que este trabalho possa contribuir para salientar a importância de valorizar as discussões em torno das múltiplas culturas na escola, trazendo as potencialidades da Astronomia cultural, pois acreditamos que desta forma, teremos uma educação mais democrática, humana e ética.

Palavras-chave: Astronomia cultural. Multiculturalismo. Ensino de Ciências. Ensino de Astronomia. Livros Didáticos. 


\begin{abstract}
OLIVEIRA, É. Multiculturalism and Science Teaching in Basic Education: Challenges and potential of cultural astronomy. 2020. Dissertation (Master's) - Instituto de Física, Instituto de Química, Instituto de Biociências e Faculdade de Educação, Universidade de São Paulo, São Paulo, 2020.
\end{abstract}

The school, a space built through historical, social and cultural processes, is the stage of multiple cultural manifestations and crossroads between them, in which respect and tolerance must be present, guaranteeing to those who attend it a democratic intercultural exchange. The study of cultural astronomy is a path to take to the Teaching of Science and Physics multicultural themes that value the various epistemologies about the sky. The legislative measure regarding Federal Law $11.645 / 08$ is of great importance for the presence of these themes throughout the curriculum. To understand how cultural astronomy reaches the classroom and the way it has been approached in academic contexts, the research in the area and textbooks approved in the PNLD of Physics and Sciences were analyzed from the perspective of content analysis, totaling 84 books. The analysis of 31 research works in the area, led to the formation of four categories that remained in the nature of other works in the area. Among them, the one with the highest number of works found is the one that groups the teaching proposals in formal education. However, although the largest number corresponds to proposals that arrive at school, some considerations are: the increase in a decade is not significant; the proposals do not deepen in the themes; the size of the works does not measure the proposals as a whole. In the analysis of LD, it was possible to count on two great dimensions of analysis "Monocultural" and "Less socially valued". It is possible to highlight that in this type of material, most of the books take a multiculturalist approach with an asyllary and differentialist bias, which has the posture of trying to integrate the less visible groups to the hegemonic culture or recognizes the particular differences of each group, however, they are books that move away from the proposal of intercultural multiculturalism, with a critical posture and dialogue between different cultural groups. We hope that this work may contribute to highlight the importance of valuing the discussions around multiple cultures at school, bringing the potentialities of cultural astronomy, because we believe that in this way we will have a more democratic, human and ethical education.

Key-words: Cultural astronomy. Multiculturalism. Science education. Astronomy education. Textbooks. 


\section{LISTA DE SIGLAS}

PIBID - Programa Institucional de Bolsas de Iniciação à Docência

UNESCO - Organização das Nações Unidas para a Educação, a Ciência e a Cultura

BNCC - Base Nacional Comum Curricular

LDB - Lei de Diretrizes e Bases

RELEA - Revista Latino-Americana de Educação em Astronomia

ISE2A - International Symposium on Education in Astronomy and Astrobiology

ISAAC - International Society for Archaeoastronomy and Astronomy in Culture

ENPEC - Encontro Nacional de Pesquisa em Educação em Ciências

SNEF - Simpósio Nacional de Ensino de Física

EPEF - Encontro de Pesquisa em Ensino de Física

SNEA - Simpósio Nacional de Educação em Astronomia

PNLD - Programa Nacional do Livro Didático

IAU - International Astronomical Union 


\section{LISTA DE GRÁFICOS}

Gráfico 1: Síntese das propostas de categorização da análise do levantamento bibliográfico 69

Gráfico 2: Resultados das coleções de Física por categoria. .95

Gráfico 3: Resultados dos livros didáticos de Física por categoria..... .96

Gráfico 4: Resultados das coleções de Ciências em cada categoria. 110

Gráfico 5: Resultados dos livros de Ciências em cada categoria 110 


\section{LISTA DE TABELAS}

Tabela 1: Resultados dos trabalhos encontrados no ENPEC dentro da linha temática "Diversidade, multiculturalismo e educação em ciências". 60

Tabela 2: Resultados dos trabalhos encontrados no SNEF dentro das categorias que abordam a cultura e a diversidade como eixo principal. 61

Tabela 3: Resultados dos trabalhos encontrados no EPEF. 62

Tabela 4: Resultados dos trabalhos encontrados no SNEA. 63

Tabela 5: Trabalhos obtidos por meio da revisão bibliográfica com suas respectivas infirmações. 64

Tabela 6: Catálogo de livros de Física - PNLD 2018 ..........................................89

Tabela 7: Catálogo de livros de Ciências - PNLD 2017........................................91

Tabela 8: Distribuição dos livros de Ciências do PNLD referente ao ano de 2017. .92

Tabela 9: Distribuição dos livros didáticos de Física por categoria...........................96

Tabela 10: Distribuição dos livros de Física na categoria Monocultural.....................97

Tabela 11: Distribuição dos livros de Física na categoria Menos Valorizados Socialmente. 102

Tabela 12: Distribuição dos livros didáticos de Ciências por categoria. 111

Tabela 13: Distribuição dos livros didáticos de Ciências na categoria Menos Valorizados Socialmente 113 


\section{LISTA DE FIGURAS}

Figura 1: Representação das categorias com relação aos livros didáticos.................94

Figura 2: Introdução do capítulo de Gravitação Universal da coleção 01 ..................98

Figura 3: Início do capítulo de Gravitação da coleção 03.......................................98

Figura 4: Tópico de eclipses e orientação do Manual do professor. Ambos referentes

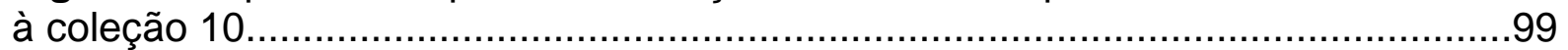

Figura 5: Leis de Kepler na coleção 12 .....................................................100

Figura 6: Capítulo dedicado à Astronomia na coleção 06...................................101

Figura 7: Conteúdo da ciência desenvolvida pelo povo árabe presente na coleção

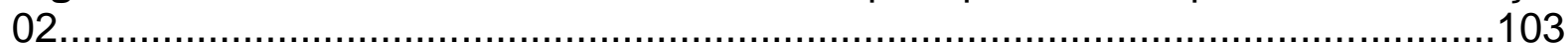

Figura 8: Conteúdo presente na coleção 04 sobre constelações indígenas brasileiras...................................................................................103

Figura 9: Atividades sobre cosmologia indígena encontrada na coleção 08 ...........104

Figura 10: Representação do eclipse pelos chineses na coleção 08......................105

Figura 11: Representação do mito caiapó encontrado na coleção 02 .....................106

Figura 12: Exemplo de constelação indígena representado na coleção 08 ..............107

Figura 13: Exercício do ENEM encontrado na coleção 08....................................108

Figura 14: Constelação da Ema presente na coleção 04.....................................109

Figura 15: Introdução à temática da astronomia no livro de $6^{\circ}$ ano na coleção $08 \mathrm{e}$ Introdução à temática da astronomia no livro de $9^{\circ}$ ano na coleção 01 , respectivamente............................................................................................112

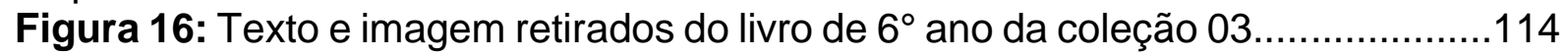

Figura 17: Livro de $9^{\circ}$ ano da coleção $07 \ldots \ldots \ldots \ldots \ldots \ldots \ldots \ldots \ldots \ldots \ldots \ldots \ldots \ldots \ldots \ldots \ldots \ldots \ldots \ldots \ldots . . .115$

Figura 18: Texto e imagem retirados da coleção 10, no tópico Constelações..........116

Figura 19: Texto e imagem retirados do livro de $6^{\circ}$ ano da coleção $03 . . . \ldots \ldots \ldots \ldots . . . . . . . .117$

Figura 20: Box encontrado na coleção 05 comparando teorias científicas e

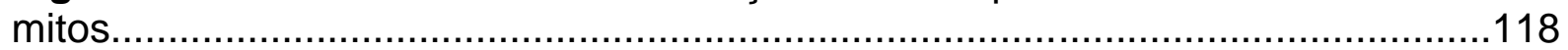

Figura 21: Atividade retirada do livro de $9^{\circ}$ ano da coleção 03..............................118

Figura 22: Questão retirada do livro de $6^{\circ}$ ano da coleção $07 \ldots \ldots \ldots \ldots \ldots \ldots \ldots \ldots \ldots \ldots \ldots . . . . .119$

Figura 23: Questões retiradas do livro de $6^{\circ}$ ano da coleção $07 \ldots \ldots \ldots \ldots \ldots \ldots \ldots \ldots \ldots . . . . . . . .119$

Figura 24: Box encontrado na coleção 02 ...................................................120

Figura 25: Páginas sobre astronomia indígena presentes na coleção 09...............121

Figura 26: Questões e suas respectivas respostas referentes à coleção 09 em livro de $6^{\circ}$ ano...........................................................................................

Figura 27: Atividade encontrada no livro de $6^{\circ}$ ano da coleção 02 e atividade encontrada no livro de $6^{\circ}$ ano da coleção 12, respectivamente...............................122

Figura 28: Atividade encontrada no livro de $6^{\circ}$ ano da coleção $10 \ldots \ldots \ldots \ldots \ldots \ldots \ldots \ldots \ldots . . .122$

Figura 29: Texto e imagem retirados do livro de $6^{\circ}$ ano da coleção $03 . \ldots \ldots \ldots \ldots \ldots \ldots . . . . .125$

Figura 30: Texto retirado do livro de $6^{\circ}$ ano da coleção $04 \ldots \ldots \ldots \ldots \ldots \ldots \ldots \ldots \ldots \ldots \ldots \ldots . . . . .125$

Figura 31: Pergunta resposta encontradas na coleção 06 em livro de $6^{\circ}$ ano...........127

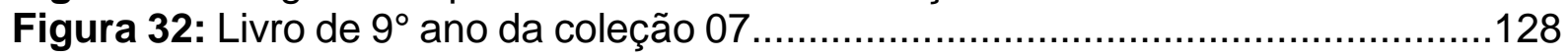




\section{SUMÁRIO}

APRESENTAÇÃO

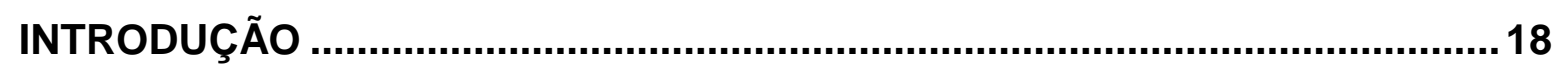

CAPÍTULO 1: AS RELAÇÕES MULTICULTURAIS NO CONTEXTO ESCOLAR 21

1.1 Cultura e Escola $\quad 22$

1.2. O papel social da escola 26

1.3. Algumas reflexões sobre currículo 31

1.3.1. Currículo: um panorama 31

1.3.2. Currículo e Multiculturalismo 37

1.3.3. Diretrizes legais e a Interculturalidade 39

1.4. Diferentes abordagens do Multiculturalismo 42

1.4.1. O multiculturalismo intercultural 44

CAPÍTULO 2: MULTICULTURALISMO E ENSINO DE CIÊNCIAS ....................47

2.1. Ciência e Cultura: a valorização dos múltiplos conhecimentos no contexto do ensino de ciências $\quad 47$

2.1.1. O ensino de Astronomia Cultural no ensino de ciências 52

2.2. Astronomia Cultural nas pesquisas em Ensino de Ciências: um panorama 54

2.2.1. Metodologias 56

2.2.2. Definição do corpus de análise 59

2.2.3. Resultados e algumas considerações 64

2.3. Algumas considerações 83

CAPÍTULO 3: ASTRONOMIA CULTURAL NOS LIVROS DIDÁTICOS E NAS PROPOSTAS DE PESQUISADORES DA ÁREA

3.1. O livro didático como elemento cultural 85

3.2. Metodologia e Definição do corpus de análise 88

3.3. Astronomia Cultural nos Livros Didáticos: Análise e resultados 94

3.3.1. Livros Didáticos de Física 95

3.3.2. Livros didáticos de Ciências 109

3.4. Considerações acerca das análises 123

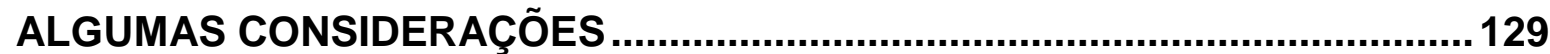

REFERÊNCIAS BIBLIOGRÁFICAS ......................................................133

LIVROS DIDÁTICOS DE CIÊNCIAS ANALISADOS ....................................141

LIVROS DIDÁTICOS DE FÍSICA ANALISADOS .........................................145

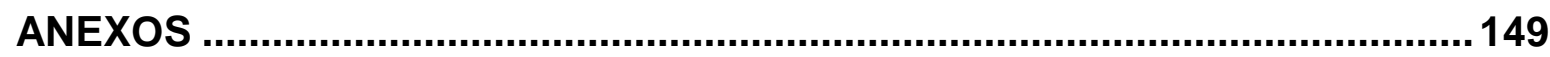




\section{APRESENTAÇÃO \\ Das brincadeiras ao ensino de Física}

"Si je ne m'étais fait poète, je serais un astronome." Maiakovski, 1927

Brincar de escolinha, sem dúvidas, era uma das minhas brincadeiras favoritas de criança. Eu podia ensinar qualquer coisa, desde como fazer uma dobradura, até coisas de anatomia que eu encontrava nas enciclopédias que tinham na minha casa. Eu tinha diário de classe, papéis e mais papéis, livros usados por mim mesma de outros anos (afinal, eu fui para a escola muito cedo), carimbos e até varal de atividades. Quando volto na memória sobre essa minha experiência nessa brincadeira, logo me encho de (talvez) uma das minhas melhores lembranças da infância: foi o dia em que percebi que eu mesma, com minha pequena-grande experiência de professora, havia alfabetizado minha irmã mais nova. Ah! Meus olhos marejaram quando vi que, na verdade, minha brincadeira era muito de verdade.

Lembro-me também como se fosse ontem, a primeira vez que ensinei (no ápice dos meus dez anos) sobre planetas para a minha pequena "sala de aula" - que se situava no meu quarto - para os meus mais de dez alunos imaginários.

A primeira vez que ouvi falar do sistema solar e de características da Terra, foi na minha aula de Geografia, quando estava na $5^{\underline{a}}$ ou $6^{\underline{a}}$ série do ensino fundamental. Achei tudo aquilo tão fabuloso e bonito que logo já tinha traçado minha profissão: Astronauta! Como poderia haver profissão melhor do que aquela que conhecia de perto o espaço sideral e os astros que o compõe? Foi daí que pensei que poderia então, na minha simples escolinha, ensinar sobre esse assunto que tanto me fascinava.

Uma outra lembrança me invade a cabeça quando volto à escolha de ser Astronauta. Desta vez, na sétima série, me questionaram: O que você quer ser quando crescer? Eu só me lembro das feições de estranhamento das pessoas e colegas de escola quando respondi "Física Nuclear". Era na expressão dos meus pais que eu encontrava impulso para ser livre na escolha do que ser no futuro, porque diante dessa minha resposta eu só ouvia "que bom, filha!". 
Minha paixão pelo cosmos se estendeu para a Física, que logo se tornou minha disciplina favorita e, consequentemente, a matéria que eu mais ia bem na escola. Durante o ensino médio, eu sempre dava aula para meus colegas de classe para tirar dúvidas, resolver exercícios e sempre senti uma satisfação tremenda em estar alí na frente do quadro negro, podendo ensinar aquilo que sei.

$\mathrm{Na}$ época do vestibular, algumas dúvidas me surgiram em relação às profissões, mas quando escolhi cursar física, foi uma libertação.

Logo depois que entrei na graduação, me decepcionei. Eram tantas reprovações logo no início que passei a me questionar se estaria no lugar certo. Como sempre gostei de dar aula, pensei em mudar para a pedagogia.

Foi então que o meu primeiro suspiro de alívio apareceu! Logo no segundo semestre cursei a disciplina de "Gravitação" (eu já estava empolgada só pela descrição da disciplina), mas como se não bastasse, tive o imenso prazer de ter aulas com o professor João Zanetic e, de cara, na primeira aula, ciência e cultura estavam interligadas. Me apaixonei!

Sempre digo que esse foi o meu primeiro suspiro para não desistir da Física.

Depois disso, segui firme na licenciatura, mas ainda não tinha "abraçado a causa" por completo. Mas, em 2015, dois eventos foram primordiais para que eu continuasse e chegasse até onde estou hoje. O primeiro deles foi a minha inserção no PIBID (Programa Institucional de Bolsas de Iniciação à Docência), onde comecei a entrar cada vez mais em contato com a escola, pude viver as dificuldades presentes nesse ambiente, pude conviver com os jovens e claro, foi nesse projeto que encontrei as belezas da astronomia cultural. Conheci os trabalhos de Germano Afonso e do Luiz Carlos Jafelice e, com isso, ajudei na construção de propostas para esse projeto.

O segundo marco importante deste ano foi cursando a disciplina "Ciência e Cultura" que percebi que estudar a relação entre escola, cultura e ciência num só semestre, seria muito pouco para mim. Eu precisava estudar essa relação de maneira mais profunda!

Quando entrei no mestrado, eu já sabia quais temáticas me tocavam e, aos poucos pude ir descobrindo esse universo. Os pequenos passos que dei, encontramse neste trabalho. 


\section{INTRODUÇÃO}

Desde a antiguidade, observar as estrelas, contemplar a Lua e penetrar na imensidão escura do céu, desperta fascínio aos olhos do ser humano. A curiosidade e a vontade de explorar o céu que nos cerca, sempre esteve presente na essência do ser humano para desvendar os mistérios e as belezas de uma simples noite estrelada. As diferentes maneiras de se olhar e compreender o céu, perpassam pela história das civilizações, onde o ser humano interpreta o Cosmos de acordo com suas necessidades, tornando o céu um elemento cultural necessário para entendermos as singularidades de cada povo.

Essas diversas perspectivas atribuídas ao significado do céu em relação ao ser humano, nos mostra a importância de considerarmos as diferentes culturas no contexto escolar, pois colaboram para: a compreensão das visões de mundo dos povos da antiguidade e das diversas culturas atuais e, o conhecimento dos contextos culturais que englobam a utilização e a observação dos fenômenos astronômicos. Atrelada a essa perspectiva, porém, de maneira mais profunda, esses conhecimentos despertam a conscientização e o respeito à diversidade, evitando, desta forma, uma visão etnocêntrica e monocultural do mundo, ressaltando que o apreço pela diferença também é componente fundamental responsável pela caracterização de uma virtude democrática, valor importante a ser cultivado na escola. (ALBUQUERQUE et al. 2011; MACHADO, 2008).

Tratando-se da Astronomia, o estudo dos astros sempre esteve presente na vida do desenvolvimento humano e, por isso, é importante levarmos em consideração os aspectos culturais da sociedade na qual se está inserido, mas também, é fundamental que haja o reconhecimento do direito à diferença, estando sempre atento às questões sociais, políticas e histórias de cada cultura (RODRIGUES, 2015).

A relação entre educação e cultura permeia o cenário mundial, onde as questões acerca do multiculturalismo se tornam distintas de acordo com o contexto no qual nos situamos, proporcionando discussões das mais variadas formas no contexto atual. De acordo com Candau (2013), a escola, por sua vez, apresenta dificuldades em lidar com a diferença e a pluralidade e afirma que o caráter monocultural e homogeneizador da escola cresce fortemente nos dias atuais, da mesma maneira como a consciência da necessidade de se romper com esses ideais, 
construindo então, processos educativos na qual o caráter multicultural esteja presente.

Diante deste cenário, o papel do multiculturalismo se torna essencial na escola para que possamos unir as diferenças culturais às práticas pedagógicas, promovendo àqueles que a frequentam, um lugar condizente com 0 mundo.

Em escala mundial, a Organização das Nações Unidas para a Educação, a Ciência e a Cultura (UNESCO) publicou em 2002 a "Declaração Universal sobre a Diversidade Cultura". Este documento é composto por 12 artigos que afirmam, além da diversidade cultural como patrimônio universal da humanidade, a importância da diversidade inserido no setor educacional.

Por essas razões, a Astronomia Cultural se torna um tema importante a ser explorado no contexto escolar, uma vez que esse estudo entrelaça diversas áreas do conhecimento, que juntas enriquecem a compreensão da relação entre o homem e o cosmos, englobando elementos que, ao longo da história, sempre fizeram parte do que se entendia por astronomia, promovendo um diálogo com os diferentes saberes de diversos grupos culturais. O que temos hoje é que a cultura dominante compartimenta os saberes e os molda para os discursos que os são mais convenientes (JAFELICE, 2010, p.248) acarretando num estudo etnocêntrico sobre os saberes do céu.

Além disso, no que diz respeito às diretrizes legais nacionais, dos elementos essenciais que favorecem a presença da Astronomia Cultural na escola básica, se refere à Lei Federal nำ11.645, vigorada desde março de 2008, que obriga o estudo da história e cultura afro-brasileira e indígena em todas as instituições de ensino fundamental e médio. O reconhecimento das concepções cosmológicas dos povos indígenas brasileiros pode ser um exemplo a ser levado para as salas de aula como uma valorização de outras visões de mundo, podendo promover a inserção do multiculturalismo intercultural (CANDAU, 2013), que visa o diálogo entre as culturas e traz uma conscientização das relações de poder que permeiam a nossa sociedade.

Diante desta discussão, reconhecendo as riquezas da astronomia cultural ser inserida no contexto escolar, este trabalho busca elucidar a importância do papel da escola na sociedade atual, trazendo dentro de uma proposta multicultural, o exemplo da Astronomia Cultural. Para isso, analisa-se um conjunto de materiais, apresentando elementos que visem e motivem levar e explorar as diversas culturas como sendo 
algo importante a ser trabalhado na escola, por conter valores éticos, humanos e que valoriza as diferentes maneiras de ser e estar no mundo.

O primeiro capítulo foi designado aos principais aspectos que envolvem a cultura e a escola, trazendo como ambas estão interligadas intrinsecamente, apresentando também, mais as problemáticas que temos no cenário atual quando tratamos de diversidade cultural dentro deste ambiente, nos perguntando se a escola está preparada para receber as culturas que não são valorizadas socialmente. Para isso, trazemos como base para esta questão, o papel do currículo e dos meios legais vigentes que defendem esta perspectiva. Por último, referimo-nos a uma abordagem mais teórica das diferentes facetas do multiculturalismo, trazendo uma ênfase maior na abordagem que defendemos desta temática.

Para o segundo capítulo, apresentamos as relações entre ciência e cultura e quais os ganhos que essa relação têm para o ensino de ciências. Por meio da defesa desta relação, a concepção de Astronomia Cultural entra como forma de promover este diálogo para dentro do contexto escolar, uma vez que, o estudo dos astros que defendemos neste trabalho é a leitura e compreensão do céu por diversos grupos culturais, onde se leva em conta suas manifestações sociais que envolvem todo o cosmos. Na segunda parte deste capítulo, apresenta-se a revisão bibliográfica realizada por meio de revistas, periódicos e eventos na área de ensino de ciências e de física que enfatizam a astronomia cultural.

O último capítulo, destina-se a tratar do livro didático, trazendo o seu papel como um dos elementos culturais indispensáveis para reconhecermos o que se chega até as salas de aula, fazendo uma análise de que forma e qual a frequência que a astronomia cultural é apresentada nestes materiais. 


\title{
CAPÍTULO 1: AS RELAÇÕES MULTICULTURAIS NO CONTEXTO ESCOLAR
}

\author{
Dê-me um cigarro \\ Diz a gramática \\ Do professor e do aluno \\ E do mulato sabido \\ Mas o bom negro e o bom branco \\ Da Nação Brasileira \\ Dizem todos os dias \\ Deixa disso camarada \\ Me dá um cigarro. \\ Oswald de Andrade - Pronominais
}

A proposta deste capítulo consiste em mostrar as relações que permeiam a escola, as culturas e os currículos de forma a construir um panorama da importância de se promover a interculturalidade no contexto escolar.

Na primeira parte, dá-se ênfase na intersecção entre a escola e cultura, que neste trabalho não é tratada somente como manifestação artística, mas sim, como um conjunto social complexo formado por histórias e relações de poder que marcam um determinado grupo.

Com isso, o próximo tópico a ser abordado trata do papel social que a escola tem no contexto atual, como esta instituição lida com as diferenças culturais e as implicações da abordagem homogênea e monocultural no que diz respeito aos conteúdos e a transmissão de uma cultura hegemônica, acarretando numa falta de diálogo com as diferenças que permeiam o ambiente educacional.

Para que o multiculturalismo seja valorizado na escola, é necessária uma discussão acerca do currículo escolar. Por essa razão, mencionamos como os saberes são selecionados para compor o currículo a partir das relações de poder de determinado grupo e os processos de disputa que encontram-se presentes neste campo. Para além disto, trazemos também a valorização e o direito à diversidade por meio das diretrizes legais brasileiras e mundiais.

Por fim, faz-se presente uma discussão sobre as definições de multiculturalismo, trazendo questões que estão vinculadas diretamente a escola e a cultura, abordando de maneira mais profunda o multiculturalismo intercultural proposto por Candau (2013). 


\subsection{Cultura e Escola}

As relações que permeiam a escola e a cultura, sempre estiveram presentes nas questões educacionais - explícita ou implicitamente. Até a década de 60, imaginavase que a instituição escolar (pública) proporcionaria, em princípio, oportunidades iguais entre os estudantes que a frequentavam, trabalhando de forma neutra e com base em critérios racionais de seleção (NOGUEIRA; NOGUEIRA, 2002). Após este período, o sistema escolar - até aqui na perspectiva mais conservadora - enfrenta novas teorias no campo da Sociologia da Educação, na qual a escola passa a ser questionada por legitimar e reproduzir as desigualdades sociais, valores e cultura oriundos da ordem dominante. (GIROUX, 1992)

Desse modo, as discussões vigentes no cenário atual fazem com que tenhamos que re-olhar essa relação, entre escola e cultura, com base em outras áreas do conhecimento como as Ciências Sociais, Antropologia e Sociologia (GABRIEL, 2000), a fim de nos dar um espectro muito mais amplo desse vínculo. Nessa perspectiva, a escola deveria ser palco dos confrontos que permeiam a sociedade como um todo, considerando os aspectos históricos, políticos, sociais e raciais, superando sua "simples função" de transmitir conteúdos.

A escola apresenta um papel central na sociedade como sendo um "espaço ecológico de cruzamento de culturas" (PÉREZ GÓMEZ, 1994; 2001 apud CANDAU, 2013). Por sua vez, pelo fato de ser construída histórica e socialmente, a escola possui uma função social fundamental, que é a de dialogar com a cultura e, por essa razão, ambas estão fortemente entrelaçadas (MOREIRA; CANDAU, 2003). A concepção de cultura aqui salientada é aquela que, segundo Candau (2000), não é dada somente por meio de desenvolvimento artístico e intelectual construídos no ambiente escolar, mas sim, composta pelas características de determinado grupo social em se expressar, se relacionar, agir no mundo e atribuir sentidos. Complementando essa concepção, utilizamos as palavras de Pérez Gómez (2001, p.17):

(...) cultura como o conjunto de significados, expectativas e comportamentos compartilhados por um determinado grupo social, o que facilita e ordena, limita e potencia os intercâmbios sociais, as produções simbólicas e materiais e as realizações individuais e coletivas dentro de um marco espacial e temporal determinado. A cultura, portanto, é o resultado da construção social, contingente às condições materiais, sociais e espirituais que dominam um espaço e um tempo. Expressam-se significados, valores, sentimentos, costumes, rituais, instituições e objetos, sentimentos (materiais e simbólicos) que circundam a vida individual e coletiva da comunidade. 
Para Bourdieu (1992, apud NOGUEIRA;NOGUEIRA 2002), a escola é uma instituição a serviço da legitimação e reprodução da dominação realizada pelas classes dominantes e, por essa razão, só se torna compreensível quando é vinculada com a relação de classes. Por meio desta, o sociólogo desenvolve a concepção de "arbitrário cultural" baseado nos estudos antropológicos de cultura. Nesta circunstância, nenhuma cultura poderia ser definida como superior a uma outra.

\begin{abstract}
Na perspectiva de Bourdieu, a conversão de um arbitrário cultural em cultura legítima só pode ser compreendida quando se considera a relação entre os vários arbitrários em disputa em uma determinada sociedade e as relações de força entre os grupos ou classes sociais presentes nessa mesma sociedade. No caso das sociedades de classes, a capacidade de legitimação de um arbitrário cultural corresponderia à força da classe social que o sustenta. De um modo geral, os valores arbitrários capazes de se impor como cultura legítima seriam aqueles sustentados pela classe dominante. Para Bourdieu, portanto, a cultura escolar, socialmente legitimada, seria, basicamente, a cultura imposta como legítima pelas classes dominantes. (NOGUEIRA; NOGUEIRA, 2002, p.28)
\end{abstract}

Essa intersecção profunda entre escola e cultura proposta por Moreira e Candau (2003) considera que a escola, ao invés de silenciar as diferenças, homogeneizando e padronizando tudo aquilo que a compõe, possa ser palco de um "arco-íris de culturas", onde haja valorização da pluralidade e leve em conta as belezas da diferença no contexto escolar. Segundo os autores, levar o cruzamento de culturas para dentro dos espaços escolares é o grande desafio da escola moderna.

A concepção de valorização da pluralidade cultural vai ao encontro da proposta de Freire (2015) sobre a reconhecimento de todas as culturas. Em suas obras, Freire nos mostra que todas as culturas devem ser consideradas e que cada ser humano se desenvolve dentro de sua compreensão de mundo. Não podemos então nos limitar apenas à compreensão e análise de mundo por meio de uma só cultura, mas sim, considerar as múltiplas interpretações culturais pois, o ser humano pela busca de sempre "ser mais" começa sua relação para e com o mundo, passando a compreendê-lo, atuando no agora, criando-o e recriando-o.

Nicodem (2015) ao analisar o conceito de cultura nas obras de Paulo Freire, apresenta que, a partir do conceito "antropológico de cultura", Freire considera não uma cultura, mas "culturas", defendendo a ideia de que não existe distinção entre a cultura popular e a erudita, tornando a cultura, o resultado de toda criação humana.

É nessa dialética entre eu-mundo e atuando nele que construímos nossa relação cultural, pois: 


\begin{abstract}
"a partir das relações do homem com a realidade, resultante de estar com ela e de estar nela, pelos atos de criação, recriação e decisão, vai ele dinamizando o seu mundo. Vai dominando a realidade, vai humanizando-a. Vai acrescentando a ele algo de que ele mesmo é o fazedor. Vai temporalizando os espaços geográficos. Faz cultura". (FREIRE, 2017a, p.60).
\end{abstract}

Moreira e Candau (2003) nos apresentam uma discussão sobre o tópico denominado "A centralidade da cultura", mostrando a importância dos estudos culturais explorando a ideia de cultura, dando-nos embasamentos que sustentam e estreitam ainda mais sua relação com a escola. Estes autores também apresentam algumas ideias de Featherstone (1997) que, em síntese, apresenta uma descentralização da cultura. Para este autor, os estudos culturais centraram-se por muito tempo nos estudos das ciências sociais, mas que, com o crescimento das áreas de transdisciplinaridade e interdisciplinaridade, a cultura precisou de uma recentralização no âmbito acadêmico. No contexto escolar, Moreira e Candau (2003) citam Michael Apple (1994), um dos autores mais conhecidos na área de teoria crítica de currículo, ressaltando que os conflitos culturais não são apenas "epifenômenos", mas são eventos necessários na luta pela hegemonia, considerando que devemos reconhecer e valorizar o universo cultural presente na sociedade sem desvinculá-lo do caráter de produção e poder das classes sociais e a força do capitalismo presente.

As ideias de Hall (1997) apresentadas pelos autores ao longo do texto, nos mostram que o autor reafirma o constante crescimento de trocas culturais e muito se deve ao desenvolvimento da tecnologia e da informática. Além disso, Hall ressalta a centralidade da cultura no contexto atual destacando seu papel essencial em todos os aspectos da vida social, ou seja, a cultura executa papel central na configuração e nas mudanças do nosso cotidiano.

\footnotetext{
"O que de fato Hall argumenta é que toda prática social depende do significado e com ele tem relação. A cultura é uma das condições constitutivas de existência dessa prática, o que faz com que toda prática social tenha uma dimensão cultural. Aceitando-se esse ponto de vista, não há como se negar a estreita relação entre as práticas escolares e a(s) cultura(s)." (MOREIRA; CANDAU, 2003, p.159)
}

Moreira e Candau (2003) ainda abordam a problemática desta relação entre cultura e escola como sendo intrínseca aos processos educativos, pois não há como desentrelaçar educação da cultura humana.

“(...) as relações entre escola e cultura não podem ser concebidas como entre dois pólos independentes, mas sim como universos entrelaçados, como uma 
teia tecida no cotidiano e com fios e nós profundamente articulados." (MOREIRA; CANDAU, 2003, p.160)

Todavia, o campo estabelecido pelo ambiente escolar não se limita a controlar as pessoas que a frequentam, mas também o conjunto de significados que alí se instauram. As escolas, como instituições pertencentes ao grupo de outras instituições políticas, culturais e econômicas, atuam em um papel relevante na preservação e na produção das desigualdades. Em outras palavras, as escolas acabam por conceder a "legitimidade cultural ao conhecimento de determinados grupos" (BOURDIEU, 1969 apud APPLE, 2006, p.104).

\begin{abstract}
"A cultura dominante nas salas de aula é que que corresponde à visão de determinados grupos sociais: nos conteúdos escolares e nos textos aparecem poucas vezes a cultura popular, as subculturas dos jovens, as contribuições das mulheres à sociedade, as formas de vidas rurais, e dos povos desfavorecidos (...). Consciente ou inconscientemente se produz um primeiro velamento que afeta os conflitos sociais que nos rodeiam quotidianamente." (SACRISTÁN, 1995 apud CANDAU, 2000, p.52).
\end{abstract}

Com isso, vemos que o modelo de escola da sociedade ocidental contemporânea, veicula uma visão homogênea, monocultural, e padronizadora de educação. Desta forma, quando aqueles considerados como "diferentes" - pessoas de origem afrodescendentes, popular, e até mesmo os rappers e funkeiros penetraram no universo escolar, "desestabilizam a lógica e instalam outra realidade sociocultural”. (MOREIRA; CANDAU, 2003).

Este cenário atual de educação nos retoma novamente à Freire. Em seu livro "Pedagogia do Oprimido" (2015) encontramos o que o autor descreve como "invasão cultural", ou seja, a "verdadeira cultura" apresentada na escola, é a cultura dominante que tem como tática a dominação, acarretando numa formação antidemocrática e ainda, lugar em que o educando não é estimulado a ser crítico e atuante do mundo em que vive.

"A invasão cultural tem dupla face. De um lado, é já dominação; de outro, é tática de dominação. Na verdade, toda dominação, implica uma invasão, não apenas física, visível, mas às vezes camuflada, em que o invasor se apresenta como se fosse o amigo que ajuda. No fundo, invasão é uma forma de dominar econômica e culturalmente o invadido. Invasão realizada por uma sociedade matriz, metropolitana, numa sociedade dependente, ou invasão implícita na dominação de uma classe sobre a outra, numa mesma sociedade. " (FREIRE, 2015, p.205) 


\subsection{O papel social da escola}

A América Latina conta com uma bagagem multicultural única, marcada por processos histórico-sociais de relações violentas e dolorosas de eliminação física, histórica e cultural, principalmente no que diz respeito aos afrodescendentes e grupos indígenas.

Nossa história permite-nos refletir de forma a nos empenharmos fortemente pela valorização da nossa própria identidade que, até hoje, precisa enfrentar os entraves das relações de poder e subalternação. Esses processos histórico-sociais chegam até os meios educativos e afetam o desenvolvimento da nossa escola: a escola brasileira.

$\mathrm{Na}$ tentativa de compreender as dificuldades de se fazer mudanças no nosso ambiente escolar, temos que primeiro trazer o nosso olhar para nossa história, que foi marcada por um forte processo de colonização - processo que vai além da exploração dos sujeitos - com a chegada-invasão dos portugueses no ano de 1500.

A história da educação brasileira se inicia em 1549 com a chegada de um grupo de jesuítas liderados por Padre Manuel da Nóbrega, e permanece no Brasil até 1749. Com a missão de converter os povos habitantes da nossa terra, em 1550 a primeira escola oficial é fundada e essa deveria seguir os padrões de educação de Lisboa (NASCIMENTO, 2007). Assim, as instituições lideradas pelos jesuítas se espalharam por diversas regiões do nosso país de forma a envolver colonização, educação e catequese.

A educação neste período é marcada pela imposição da cultura do colonizador para o meio dos colonizados, surgindo "como um fenômeno de aculturação, tinha na catequese a sua ideia-força (...) " (SAVIANI, 2011, p.31). Segundo o autor, a educação colonial no Brasil passa pela fase do "período heróico", que abrange a fundação das escolas jesuítas, a difusão do ideário pedagógico no Ratio Studiorum e finaliza com a fase Imperial com a vinda de Dom João VI ao Brasil.

O plano de instrução era consubstanciado na Ratio Studiorum, cujo ideal era a formação do homem universal, humanista e cristã. A educação se preocupava com o ensino humanista de cultura geral, enciclopédico. [...] Esses eram os alicerces da Pedagogia Tradicional na vertente religiosa [...], é marcada por uma "visão essencialista de homem, isto é, o homem constituído por uma essência universal e imutável". A essência humana é considerada criação divina e, assim, o homem deve se empenhar para atingir a perfeição, "para fazer por merecer a dádiva da vida sobrenatural." (SAVIANI, 1984, p. 12). 
Para que tenhamos uma breve ideia do que foi a primeira fase da educação jesuítica no nosso país com o plano educacional realizado por Manuel da Nóbrega, utilizamos as palavras de Saviani (2011):

"O plano iniciava-se com o aprendizado do português (para os indígenas);
prosseguia com a doutrina cristã, a escola de ler e escrever e, opcionalmente,
canto orfeônico e música instrumental; e culminava, de um lado, com o
aprendizado profissional e agrícola, de outro lado, com a gramática latina
para aqueles que se destinavam à realização de estudos superiores na
Europa (Universidade de Coimbra)." (SAVIANI, 2011, p.43)

Podemos perceber que foram inúmeros os impactos desta educação para a época, mas o que podemos perceber é que o modelo de educação ocidental europeu vai se perpetuar no nosso país por longos anos, tendo em vista que as primeiras ideias de educação popular surgiram somente anos mais tarde, apenas com o retorno da família real para Portugal e com a nossa independência. É somente entre as décadas de 20 e 30 do século XX, que o Brasil começa a sentir as questões acerca de se copiar as escolas estrangeiras. (TEIXEIRA, 1969)

\footnotetext{
"Numa das escolas se pretendia educar a mente e noutra as mãos - como se vivêssemos numa sociedade em que uns trabalhassem e produzissem e outros apenas gozassem e contemplassem. Assim fora, em toda a antiguidade e assim fora, com efeito, entre nós, durante todo o regime colonial e monárquico, fundado na escravidão. Suprimida esta, o nosso enraizado espírito de classe no sentido corrente de qualificação "social" entrou a cultivar uma falsa teoria pedagógica (...), propícia à conservação dos preconceitos caros à nossa tradição" (TEIXEIRA, 1969, p.69)
}

É por meio de histórias como a nossa que percebemos que as mudanças educacionais brasileiras contam com uma temporalidade que as difere de outros sistemas que não passaram por processos tão profundos e longos de imposição à cultura dominante, visto que, pelas palavras de Anísio Teixeira (1969), o nosso contexto social nos dava um caráter de anacronismo como país recém "descoberto" perante aos conflitos concomitantes ao contexto europeu.

A escola, com suas múltiplas funções e propósitos, acaba por ser uma instituição complexa, com uma organização própria e com alta responsabilidade perante a formação de todos nós, homens e mulheres.

Pérez Gomes (2001) refere-se à três funções na qual a escola encontra-se presente: a função socializadora, função instrutiva e função educativa. A primeira delas traz a escola como instituição social na qual os sujeitos que à pertencem, 
exercem diversas socializações, onde os intercâmbios são guiados pela cultura dominante do contexto político e econômico. Nesse sentido, as socializações que ocorrem nesse ambiente se moldam na medida em que as transformações sociais acontecem, ou seja, se há modificações nos valores e atitudes na sociedade como um todo, logo as relações presentes na escola também se alteram.

A segunda função, determinada como instrutiva, se desempenha na medida em que as atividades de ensino-aprendizagem são encaminhadas para um melhor desempenho dos processos de socialização, de forma a pretender que sejam espontâneos e melhorem as organizações de convivência dos sujeitos. Todavia, as desigualdades que perpetuam nas sociedades, passam pelos muros da escola, afetando esses processos de socialização.

"É ingênuo pretender que a escola consiga superar tais desigualdades econômicas e culturais, mas pode sim e deve oferecer a possibilidade de compensar em parte os efeitos de tão escandalosa discriminação no desenvolvimento individual dos grupos mais marginalizados." (PÉREZ GÓMEZ, 2001, p.263)

Ainda nesta perspectiva acerca das desigualdades presentes neste ambiente, Apple (1989a) ressalta que a escola tem como papel causar a "amplificação do desajustamento". A escola então, torna-se agente responsável pela reprodução econômica e cultural das relações de classe. Uma instituição que também tem por função ser um aparato ideológico do estado, atendendo as necessidades da divisão social. Assim, o ambiente escolar é mantenedor dos privilégios da cultura dominante e legitima o conhecimento dos grupos favorecidos.

"As escolas, portanto, são também agentes no processo de criação e recriação de uma cultura dominante eficaz. Elas ensinam normas, valores, disposições de uma cultura, que contribuem para a hegemonia ideológica dos grupos dominantes." (WILLIAMS, 1977 apud APPLE, 1989a, p.58)

Nesse contexto, entre as funções desempenhadas pela instituição escolar, encontramos os Aparelhos Ideológicos do Estado (AIE) concebidos por Althusser (s.d.), que dialogam com as concepções apresentadas pelos outros autores, de se ter a escola como capaz de reproduzir as lógicas hegemônicas.

"Como AIE dominante, vale dizer que a escola constitui o instrumento mais acabado de reprodução das relações de produção de tipo capitalista. Para isso, ela toma a si todas as crianças de todas as classes sociais e inculcaIhes durante anos a fio de audiência obrigatória "saberes práticos" envolvidos na ideologia dominante." (ALTHUSSER, s.d.apud SAVIANI, 2008, p.) 
Oferecer contrastes dos processos de socialização pelos sujeitos da escola e experiências que ultrapassam as culturas vividas e manifestadas dentro do contexto escolar e, explorar os saberes distantes no tempo e no espaço, constituem a terceira função da escola, que tem como centralidade romper as barreiras entre escola e sociedade.

Essa prática educativa da escola ultrapassa às normas cultas e currículos propostos, mas de uma maneira natural precisa ser espaço onde "estudantes e docentes aprendem ao mesmo tempo que vivem ao mesmo tempo que aprendem os aspectos mais diversos da experiência humana". (PÉREZ GOMES, 2001, p.264)

Candau (2013) afirma que o caráter monocultural e homogeneizador da escola cresce fortemente, da mesma maneira como a consciência da necessidade de se romper com esses ideais, construindo então, processos educativos no qual o caráter multicultural esteja presente.

Esta postura homogênea da escola está interligada de forma direta no que diz respeito aos conteúdos nela veiculados, sustentando a memorização e afastando a compreensão da realidade, mas também é baseada nesta estrutura que a escola é responsável por apresentar quais culturas são mais valiosas, restringindo-se a cultura ocidental. É por meio desta transmissão de "cultura valiosa", que a sociedade se enraíza em modelos e padrões ocidentais de verdade, de ser humano, de beleza, de ideal e de bondade. Tão grave é essa universalização da cultura imposta pela escola que, desde cedo, as crianças pertencentes às famílias menos valorizadas socialmente, são obrigadas a cultivar os valores desta cultura "maior", deslegitimando aquilo que provêm de sua própria cultura e desprezando-se as bagagens culturais de cada indivíduo, fazendo da escola um ambiente onde tudo deve ser aprendido (BOURDIEU, 2015; FREIRE, 2017a; PÉREZ GÓMEZ, 2001).

Além da instituição escolar ter se tornado um grande espaço onde as políticas neoliberais atuam buscando eficiência nos mecanismos pedagógicos ao mínimo custo e altas produções, a escola se restringe aos interesses do mercado de trabalho e aos conhecimentos pautados nos interesses da cultura dominante, ignorando as diferenças presentes neste ambiente (PÉREZ GÓMEZ, 2001). Por essa razão, compreender os desafios relacionados aos processos educativos vão para além da eficácia de fatores organizativos, mas sim, entender quais elementos escolares constituem a formação de um indivíduo crítico, enriquecido de pensamentos, 
experiências, desejos e afeto, não deixando de lutar por inserir uma interculturalidade ampla e flexível que abrace e diversidade presente no mundo.

\begin{abstract}
"A educação dos(as) meninos(as) é um fenômeno complexo que implica estruturas organizativas, identidades pessoais, dinâmicas interpessoais e comunicações simbólicas. Compreender o que acontece numa determinada escola não é facilmente acessível por meios simples e diretos. Em consequência, a educação como experiência viva, deve ser compreendida através da observação das pessoas, quando se implicam em diferentes tipos de experiências comunicativas, quando manifestam suas identidades pessoais, quando criam estruturas, rituais e símbolos que se expressam seus valores e ideias" (GOODMAN, 1992, apud PÉREZ GÓMEZ, 2001, p.150).
\end{abstract}

Com isso, a presença do multiculturalismo torna-se essencial na escola para que possamos unir as diferenças culturais a práticas pedagógicas, promovendo àqueles que a frequentam, um lugar condizente com o mundo em que vivem, levando em conta a tolerância, o respeito e a diversidade de pertencimentos. (CANDAU, 2013; FORQUIN, 2000)

"(...) não é possível conceber uma experiência pedagógica "desculturalizada", isto é, desvinculada totalmente das questões culturais da sociedade. Existe uma relação intrínseca entre educação e cultura (s). " (CANDAU, 2013, p.13).

Desta forma, acreditamos que valorizar a pluralidade cultural no contexto escolar é ir contra qualquer prática etnocêntrica, racista ou xenofóbica, que desrespeita os grupos minoritários, fazendo da escola, uma instituição mais democrática e que valoriza os saberes produzidos por todos que atuam no mundo.

Todavia, para que haja um ensino multicultural é necessária uma postura crítica do educador perante as relações de conflito presentes no contexto escolar. É de extrema importância que o educador promova um diálogo entre os diversos grupos sociais e culturais de reconhecimento do "outro", sem esconder as críticas presentes nos processos de dominação cultural, estimulando os alunos, colocar-se no lugar/posição do "outro" pois, somente desta forma, seremos capazes de promover propostas didáticas e mudanças reais no currículo de forma a valorizar essencialmente a diversidade.

Como ressalta Forquin (2000), "um ensino pode estar endereçado a um público culturalmente plural sem ser, ele mesmo, multicultural. Ele só se torna multicultural quando desenvolve certas escolhas pedagógicas que são, ao mesmo tempo, escolhas éticas ou políticas". 


\subsection{Algumas reflexões sobre currículo}

\subsubsection{Currículo: um panorama}

Falar a respeito do currículo - e tudo o que o envolve- é sempre algo difícil no sentido de estabelecer quais são os limites e a profundidade no qual devemos analisar as suas múltiplas concepções, teorias, autores e ideias. Entretanto, parece-nos consensual - com o apoio das teorias críticas - considerar que o currículo não é mero dado, mas uma construção social e, por essa razão, tem um diálogo intrínseco entre sociedade e escola. Esta concepção pode ser um bom ponto de partida para delimitar o que queremos então abordar sobre o currículo neste trabalho. Conhecer como alguns saberes chegam até a escola e suas relações com o poder existente na sociedade e a importância de se ter um currículo que aborde as diversas culturas, são alguns dos pontos escolhidos para serem tratados neste tópico.

No que diz respeito aos saberes que chegam até a escola, podemos dizer que o currículo é o núcleo e o espaço central estruturante da função escolar (ARROYO, 2013) e, por isso, tem grande influência para selecionar quais são os conhecimentos/saberes "mais pertinentes" para serem legitimados e reconhecidos no contexto escolar. Por essa razão, o debate sobre o currículo deveria estar no centro de toda reflexão social de educação (FORQUIN, 1992).

Um dos motivos da importância de discutir o currículo se dá pela alta responsabilidade da escola, que não só controla as pessoas que alí se encontram, de investir e gerar bens materiais e travar interações sociais e de poder, mas também, a escola como atuante no controle de significado, perseverando com o conhecimento que "todos devemos ter", em que a capacidade do conhecimento de um determinado grupo se tornar o "conhecimento de todos" está relacionado ao poder que este grupo tem nas arenas políticas e econômicas. (FORQUIN, 1992; APPLE, 2006; SANTOS, 1995)

Como ressalta Michael Apple (2013, p.52):

(...) a decisão de se definir o conhecimento de alguns grupos como digno de ser transmitido às gerações futuras, enquanto a história e a cultura de outros grupos mal vêem a luz do dia, revela algo extremamente importante acerca de quem detém o poder na sociedade. 
Para Arroyo (2013), a produção e a apropriação de um dado conhecimento sempre estiveram nas disputas sociais e políticas de dominação-subordinação. Ou seja, em nossa formação histórica, a negação de saberes de alguns grupos sociais, étnicos, raciais, de campo e gênero, sempre esteve presente. Para o autor:

\begin{abstract}
"Não apenas foi negado e dificultado o acesso ao conhecimento produzido, mas foram despojados de seus conhecimentos, culturas, modos de pensarse e de pensar o mundo e a história. Foram decretados inexistentes, à margem da história intelectual e cultural da humanidade. Logo, seus saberes, culturas, modos de pensar não foram incorporados no dito conhecimento socialmente produzido e acumulado que as diretrizes curriculares legitimam como núcleo comum. " (ARROYO, 2013, p.14)
\end{abstract}

Esses saberes que são tradicionalmente escolhidos, induzem na educação direta ou indiretamente - das maneiras de ser, de pensar e se expressar, modelos e valores, contribuindo para a construção de identidades sociais e culturais (MOREIRA; CANDAU, 2007), formadas a partir de uma visão restrita - na maioria das vezes com os olhos eurocêntricos - que consolidam as situações de discriminação e representações estereotipadas de determinados grupos sociais e, por essa razão, se podemos dizer que o currículo é o espaço onde se travam as lutas em torno dos diferentes significados sobre o político e o social, a cultura faz parte intrínseca deste meio.

“(...) o currículo não é o veículo de algo a ser transmitido e passivamente
absorvido, mas o terreno em que ativamente se criará e produzirá cultura. O
currículo é, assim, um terreno de produção e de política cultural, no qual os
materiais existentes funcionam como matéria-prima de criação, recriação e,
sobretudo, de contestação e transgressão. " (MOREIRA; SILVA, 2013, p.28)

Com o intuito de conhecermos um pouco mais as diferentes vertentes que permeiam os estudos acerca das teorias de currículo, nos dedicaremos a trazer, de maneira sucinta, do que consistem as teorias tradicionais, críticas e pós-críticas de currículo, de forma a apresentar quais elementos às diferem e as características gerais acerca do papel do currículo em cada uma delas.

Em linhas gerais, o que dissocia as teorias tradicionais das críticas e pós-críticas são as compreensões das questões do poder. No âmbito das teorias tradicionais, encontramos uma atenção maior nos processos que envolvem a organização do currículo. Desta forma, aproxima-se do próprio fazer e elaborar o currículo, resumindoo quase a uma tarefa técnica. As teorias tradicionais se firmam numa posição de não 
questionamento às questões de poder e afirmam serem neutras, científicas e desinteressadas. Por conta dessa posição, as teorias tradicionais preservam a desigualdade e acarretam por manter alguns privilégios de grupos que são favorecidos socialmente. (MOREIRA, SILVA, 2013; SILVA, 2019)

As teorias críticas e pós-críticas se fundamentam nas análises políticas de poder, em confronto com as teorias tradicionais. Nesse contexto, ambas argumentam de que nenhuma teoria pode ser neutra e, diferentemente das teorias tradicionais, não perguntam "o que” está no currículo, mas "por quê" esse e não outro (SILVA, 2019). Desta forma, passam a se preocupar com os vínculos entre poder, saber e identidade, criticam o status quo e buscam entender a implicações das escolhas de determinados conhecimentos na formação do currículo.

Ainda que ambas as teorias - críticas e pós-críticas - provenham das mesmas questões, podemos dizer que, em alguns sentidos, se diferenciam bastante. A começar que a primeira delas se fundamenta na análise da economia política de poder por meio da ótica materialista marxista, enquanto a outra, busca analisar as formas textuais e discursivas sob as hipóteses pós-modernas, pós-estruturais, dos estudos culturais e pós-coloniais, do meio ambiente, do gênero, da raça e da sexualidade (MOREIRA; SILVA, 2013).

A teoria crítica de currículo surge na década de 70 e, com ela, aprendemos que o currículo é uma construção social e espaço de disputa de poder, sendo de importante elemento para a reprodução das estruturas de classe do capitalismo. Nesse cenário, os processos de dominação presentes se dão pelo estudo das classes sociais, no qual

"O currículo atua ideologicamente para manter a crença de que a forma capitalista de organização da sociedade é boa e desejável. Através das relações sociais do currículo, as diferentes classes sociais aprendem quais são seus respectivos papéis nas relações sociais mais amplas." (SILVA, 2019. p.148)

É na segunda metade dos anos 90 que as teorias pós-críticas surgem como forma de complementar e trazer à tona uma perspectiva mais ampla das questões abarcadas nas teorias críticas, oferecendo novas influências, temáticas e, consequentemente, novas problemáticas. Esse novo olhar mais amplo enfatiza que o currículo não pode trazer uma análise somente na questão do poder centrado no 
Estado e na classe social, mas toma conta de toda uma rede que permeia a sociedade, estando nos espaços da etnia e do gênero, por exemplo.

Em suma, as teorias pós-críticas complementam as críticas, no sentido de aumentar os horizontes de conflitos e nas implicações sérias que são trazidas pelo currículo. Desta maneira, podemos entender a seriedade desse território que é tão necessário, complexo e denso.

Exatamente por ser uma arena disputada que o currículo está inteiramente ligado à ideologia e ao poder.

Desde o início dos estudos da teoria crítica de currículo, os conceitos relacionados a "ideologia" estiveram presentes. Althusser (1983 apud MOREIRA, SILVA, 2013) em seu ensaio sobre a relação entre a ideologia e os aparelhos do Estado, caracteriza o início de uma discussão no qual esses conceitos estariam inseridos no contexto educacional trazendo à tona, uma crítica às Teorias Tradicionais. Nesta nova fase marcada pela obra de Althusser, a educação não é mais "somente" a transmissão de conteúdos, mas está embebida de uma ideologia na qual a classe dominante transmite suas ideias de mundo, acarretando por manter as divisões sociais e desigualdades existentes. No que diz respeito à essa transmissão ideológica presente na escola, Althusser (Ibidem, p. 30) ressalta que estaria mais fortemente ligada à disciplinas de caráter social (Geografia, História, Educação Moral, etc.), mas que também se encontraria presentes naquelas que aparentemente não haveria uma maneira de controle ideológico, como a matemática e as de Ciências da Natureza.

Com relação ao papel dos educadores e das educadoras e o diálogo com 0 currículo, salientamos que reconhecemos o quanto é difícil romper com os moldes já pré-definidos e ainda, se engajar na mudança dessa ideologia opressora que permeia toda a nossa formação e deságua na sala de aula.

\footnotetext{
"Peço desculpas aos professores que, em condições terríveis, tentam voltar contra a ideologia, contra o sistema e contra as práticas em que este os encerra, as armas que podem encontrar na história e no saber que "ensinam". Em certa medida são heróis. Mas são raros, e quantos (a maioria) não têm sequer um vislumbre de dúvida quanto ao "trabalho" que o sistema (que os ultrapassa e esmaga) os obriga a fazer, pior, dedicam-se inteiramente e em toda a consciência à realização desse trabalho (os famosos métodos novos!). Têm tão poucas dúvidas, que contribuem até pelo seu devotamente a manter e a alimentar a representação ideológica da Escola que a torna hoje tão "natural", indispensável-útil e até benfazeja aos nossos contemporâneos, quanto a Igreja era "natural", indispensável e generosa para os nossos antepassados de há séculos." (ALTHUSSER, s.d. apud SAVIANI, 2008, p.).
} 
No que diz respeito às congruências entre poder e currículo, essa conexão fica bastante explícita nas ideias de Michael Apple (1989b), uma vez que, o cerne de sua teoria é a equação estabelecida entre o Currículo e o Poder. De um lado temos as estruturas econômicas e sociais mais amplas com a reprodução e consumos de recursos materiais e, de outro, a produção, reprodução e consumos dos recursos que são simbólicos (onde se estabelece a educação e o currículo) e, tudo isso, mediado pelas ações humanas. Ou seja, o que ocorre no campo educacional e, consequentemente de currículo, não está dito somente pelo andar econômico, mas também de uma série de movimentos postos pelos campos culturais, que funcionam em uma outra ordem. Dessa forma, Apple (2006) volta-se ao conceito de hegemonia, como algo que transita por esses vínculos citados, no qual a dominação econômica se transforma na hegemonia cultural. Dialogando com a escola, a preocupação do autor não está na validade do conhecimento em si que é posto no âmbito educacional, mas a questão central seria saber qual conhecimento é considerado como verdadeiro.

Apesar de, cronologicamente, suas teorias terem sido publicadas antes dos autores aqui citados, Paulo Freire desenvolve uma concepção crítica de currículo que entrelaça os pontos abordados, acrescentadas à uma perspectiva otimista e esperançosa de transformação social. O currículo na perspectiva freireana abarca a política, a teoria e a prática do que fazer na escola e para além dela no sentido críticotransformador. Para Freire, a questão não seria "o que ensinar", mas tem em seu pensamento uma fundamental questão epistêmica sobre "o que significa conhecer?" e, com isso, acaba por não se limitar a analisar como é a educação ( como um todo), mas como ela então deveria ser. Para o autor, mudar o mundo e mudar as pessoas, tudo faz parte de um mesmo processo de mudança e, por essa razão, deve-se ter uma educação para a transformação.

Podemos dizer que a maior crítica de Paulo Freire (2015) com relação ao currículo, está nas concepções de "educação bancária" e "educação problematizadora". A educação bancária, que muito se alinha com as teorias tradicionais de currículo, compreende os (as) estudantes como sujeitos não ativos no processo de educação, se tornando meros depositários de conteúdos, em que o depositante é o professor. Nessa concepção, o único sujeito que tem posse do "saber" é o professor, que narra os conteúdos por meio de uma aprendizagem mecânica. Desta forma, não existe a possibilidade de pensamento crítico, criativo e, 
principalmente, de transformação de mundo, posto que, no pensamento freireano "Só existe saber na invenção, na reinvenção, na busca inquieta, impaciente, permanente, que os homens fazem no mundo, com o mundo e com os outros. Busca esperançosa também." (FREIRE, 2015, p.81)

"Na visão "bancária" de educação, o "saber" é uma doação dos que julgam sábios aos que julgam nada saber. Doação essa que se funda numa das manifestações instrumentais da ideologia da opressão - a absolutização da ignorância, que constitui o que chamamos de alienação da ignorância, segundo a qual esta se encontra sempre no outro." (FREIRE, 2015, loc.cit.)

O pensamento de Paulo Freire vai para além de trazer um outro tipo de educação que não segue as normas de simplesmente fazer depósitos de conteúdos aos (às) estudantes, mas propõe uma educação que seja para a libertação dos sujeitos. A "educação problematizadora" - ou libertadora - se baseia na ação dialógica entre educador-educando em que ocorre uma aprendizagem mútua, mediatizados pelo mundo. Nesta concepção, os homens e as mulheres são seres inacabados, inconclusos e que compreendem que possuem uma vocação ontológica e histórica de ser mais. Por meio da educação, todos os sujeitos devem lutar e se engajar para a libertação, que só acontece por meio da relação construída entre professor-aluno em que, juntos, dialogam, problematizam o mundo e, assim, constroem o conhecimento. Problematizar é aqui, analisar o mundo e suas relações com os sujeitos que o atuam, de maneira crítica à fim de transformá-lo, ação que só pode ser possível por meio do diálogo. Desta forma, todo ato pedagógico é também dialógico.

A certa maneira, Paulo Freire (2015) ao tratar dos processos sociais e educacionais como uma relação opressor-oprimido, no qual um sempre dita as regras do jogo e o outro se mantém calado em busca de sua libertação, também acaba por trazer - ainda que implicitamente - uma visão cultural de currículo, principalmente quando tratamos de pedagogias pós-coloniais - na relação colonizador-colonizado. Para Freire, não existem linhas que separam a cultura erudita da cultura popular, nem existem critérios para a classificação de que uma seja esteticamente ou filosoficamente melhor do que outra e, consequentemente, faria mais sentido dizermos "culturas" ao invés de "cultura". Essa ampliação do pensamento freireano abre portas para que a "cultura popular", aquela que vêm das massas, dos povos oprimidos e grupos negligenciados, façam parte legítima do currículo. 


\subsubsection{Currículo e Multiculturalismo}

A diversidade cultural tem feito parte das questões curriculares, de modo que as discussões da conexão entre currículo e multiculturalismo venham se tornando cada vez mais presentes no cenário atual sobre educação. Nesse sentido, compreender o que seria então um currículo multicultural, torna-se essencial.

Silva (2019) nos mostra que existem diversas perspectivas multiculturalistas e que, apesar de convergirem na defesa de não haver hierarquias entre as culturas humanas - todas as culturas seriam equivalentes no sentido epistemológico e antropológico - , essas perspectivas apresentam diferenças que são significativas e que devem ser pontuadas.

O autor apresenta a primeira concepção como "multiculturalismo liberal ou humanista", em que o currículo, neste caso, se basearia nas ideias de respeito, tolerância e "convivência harmoniosa entre as culturas" (SILVA, 2019) em nome de uma essência (humanidade) comum. Todavia, o apelo à essência, torna por deixar de fora do currículo as questões históricas e sociais presentes nas relações.

A outra perspectiva apresentada, denominada de "multiculturalismo crítico", está dividida em outras duas vertentes: pós-estruturalista e "materialista". Para os pósestruturalistas, a diferença está essencialmente relacionada aos processos de discursos e da língua e, para além disso, está sempre posta como uma relação entre "diferente" e "não-diferente" que são condizentes com relações de poder de um determinado grupo. No caso dos "materialistas" - inspirado nas concepções do marxismo - o foco estaria nos processos econômicos e institucionais que, estariam no alicerce da produção dos processos de desigualdade e discriminação baseados na diversidade cultural.

Por essas razões, o currículo desta perspectiva confronta as visões do caso do "multiculturalismo liberal", pois somente enfatizar o respeito e a tolerância faz com que as relações de poder - responsáveis pela produção das diferenças - permaneçam intactas e inquestionáveis.

"Apesar de seu impulso aparentemente generoso, a ideia de tolerância, por exemplo, implica também uma certa superioridade por parte de quem mostra a "tolerância". Por outro lado, a noção de "respeito" implica um certo essencialismo cultural, pelo qual as diferenças culturais são vistas como fixas, como já definitivamente estabelecidas, restando apenas "respeitá-las". (SILVA, 2019, p.88) 
O currículo "crítico" seria aquele que não se limitaria a ensinar somente a tolerância e o respeito, mas teria a intenção de trazer à tona a reflexão pelo qual as diferenças são produzidas pelas relações de desigualdade, ou seja, a diferença é posta em questão.

Para além das vantagens e/ou desvantagens dos currículos baseados nas propostas anteriores, o multiculturalismo nos mostra que os níveis de desigualdade quando se diz respeito ao currículo e cultura, transpassa pela dinâmica de classes, mas penetra em outras questões de raça, etnia, gênero, sexualidade, tornando a mudança nos currículos uma questão estritamente necessária.

Tratando-se da padronização curriculares, uma possível estratégia para romper com essa tradição, é fazer da escola um espaço de crítica cultural, de diálogo, onde desconstrói-se as configurações monoculturais que permeiam este ambiente e as políticas educacionais, adquirindo uma postura ética de uma não hierarquização de grupos sociais (GOMES, 2007). "A escola precisa, assim, acolher, criticar e colocar em contato diferentes saberes, diferentes manifestações culturais e diferentes óticas. " (MOREIRA; CANDAU, 2007).

Desta forma, a pluralidade cultural deve vir à tona na formulação de currículos, de forma que seja possível compreender o mundo a partir de diferentes formas, rompendo com a visão etnocêntrica que são inseridos. Segundo Akkari (2010 apud SANTIAGO, AKKARI, MARQUES, 2013):

O etnocentrismo pode implicar julgamentos de valores relativos a outros indivíduos, possuidores de uma cultura cujas práticas são incompreensíveis porque são desconhecidas.

Por isso, levar a diversidade para a escola promove aos alunos e alunas uma reflexão sobre as questões históricas, culturais e políticas, dialogando com as diferenças e contribuindo por uma formação de respeito e democracia. Santiago, Akkari e Marques (2013) ainda ressaltam as palavras de Forquin (1992) sobre esta questão:

(...) a abordagem interculturalista privilegia a mudança em contraponto à continuidade, a transformação em contraponto à conservação. A abordagem interculturalista em educação descortina um novo rumo à construção de novas relações identitárias, em que o reconhecimento do outro seja uma dimensão constitutiva de cada indivíduo e esteja presente na cultura institucional da escola. (p.48) 


\subsubsection{Diretrizes legais e a Interculturalidade}

No que diz respeito aos documentos legais que justificam a inserção dos saberes multiculturais no contexto escolar e ainda, como conhecimento a ser legitimado e reconhecido, temos, em escala mundial, a "Declaração Universal sobre a Diversidade Cultural" produzido pela Organização das Nações Unidas para a Educação, a Ciência e a Cultura (UNESCO) publicada em 2002. Este documento é composto por 12 artigos que afirmam a diversidade cultural como patrimônio universal da humanidade, sendo a cultura como

"[...] o conjunto dos traços distintivos espirituais e materiais, intelectuais e afetivos que caracterizam uma sociedade ou um grupo social e que abrange, além das artes e das letras, os modos de vida, as maneiras de viver juntos, os sistemas de valores, as tradições e as crenças. " (UNESCO, 2002, p.2)

Quanto à importância da diversidade cultural, o Artigo 1 - "A diversidade cultural, patrimônio comum da humanidade", declara:

\footnotetext{
"A cultura adquire formas diversas através do tempo e do espaço. Essa diversidade se manifesta na originalidade e na pluralidade de identidades que caracterizam os grupos e as sociedades que compõem a humanidade. Fonte de intercâmbios, de inovação e de criatividade, a diversidade cultural é, para o gênero humano, tão necessária como a diversidade biológica para a natureza. Nesse sentido, constitui o patrimônio comum da humanidade e deve ser reconhecida e consolidada em benefício das gerações presentes e futuras. " (UNESCO, 2002, p.3, grifo nosso)
}

A declaração também ressalta a importância da diversidade inserida no setor educacional: "Promover, por meio da educação, uma tomada de consciência do valor positivo da diversidade cultural e aperfeiçoar, com esse fim, tanto a formulação dos programas escolares como a formação dos docentes. " (UNESCO, 2002, p.6, item.7)

No contexto nacional, encontramos na Constituição Federal de 1988 a presença de uma seção do capítulo III ("Da Educação, da Cultura e do Desporto") destinada à cultura na qual declara-se tudo aquilo que constituímos como patrimônio cultural do Brasil:

"Art. 216. Constituem patrimônio cultural brasileiro os bens de natureza material e imaterial, tomados individualmente ou em conjunto, portadores de referência à identidade, à ação, à memória dos diferentes grupos formadores da sociedade brasileira, nos quais se incluem: (EC no 42/2003) I-as formas de expressão; II-os modos de criar, fazer e viver; III-as criações científicas, artísticas e tecnológicas; IV-as obras, objetos, documentos, edificações e demais espaços destinados às manifestações artístico-culturais; V-os 
conjuntos urbanos e sítios de valor histórico, paisagístico, artístico, arqueológico, paleontológico, ecológico e científico." (BRASIL, 2016, p.126)

No contexto brasileiro, após a vigência da Lei no $13.415 / 2017^{2}$, que altera a Lei no 9.394/1996, que estabelece as diretrizes e bases da educação nacional, o Conselho Nacional de Educação (CNE) junto do Conselho Pleno (CP) implementa em 2017 a Resolução CNE/CP № 2 que institui e orienta a Base Nacional Comum Curricular (BNCC) como documento a ser obrigatoriamente respeitado ao longo de toda a Educação Básica. Nesta legislação, destacamos o artigo abaixo que diz respeito à proposta pedagógica da BNCC:

Art. $7^{\circ}$ Os currículos escolares relativos a todas as etapas e modalidades da Educação Básica devem ter a BNCC como referência obrigatória e incluir uma parte diversificada, definida pelas instituições ou redes escolares de acordo com a LDB, as diretrizes curriculares nacionais e o atendimento das características regionais e locais, segundo normas complementares estabelecidas pelos órgãos normativos dos respectivos Sistemas de Ensino. (BRASIL,2017, p.6)

A nova BNCC, publicada em 2017, que consiste em um documento de caráter normativo, define as aprendizagens essenciais que crianças e jovens devem desenvolver ao longo das etapas e séries da educação básica. Este documento é orientado por meio de princípios éticos e aspira por uma formação humana em busca de se construir uma sociedade mais democrática, inclusiva e justa. (BRASIL, 2017)

De maneira geral, a BNCC traz consigo aprendizagens que os autores visam serem essenciais para guiar os educandos a desenvolver competências ao longo da vida escolar. Competência essa que é definida como "a mobilização de conhecimentos (conceitos e procedimentos), habilidades (práticas, cognitivas e socioemocionais), atitudes e valores para resolver demandas complexas da vida cotidiana, do pleno exercício da cidadania e do mundo do trabalho." (BRASIL, 2017,p.15). Além disso, a BNCC conta com uma escola que tenha papel democrático de forma a respeitar as diversidades presentes no Brasil.

\footnotetext{
2 BRASIL. Lei no 13.415 , de 16 de fevereiro de 2017. Altera as Leis oㅜ 9.394, de 20 de dezembro de 1996, que estabelece as diretrizes e bases da educação nacional, e 11.494, de 20 de junho 2007, que regulamenta o Fundo de Manutenção e Desenvolvimento da Educação Básica e de Valorização dos Profissionais da Educação, a Consolidação das Leis do Trabalho - CLT, aprovada pelo Decreto-Lei no 5.452, de $1^{\circ}$ de maio de 1943, e o Decreto-Lei oㅡ 236, de 28 de fevereiro de 1967; revoga a Lei oㅡ 11.161, de 5 de agosto de 2005; e institui a Política de Fomento à Implementação de Escolas de Ensino Médio em Tempo Integral. Diário Oficial da União, Brasília, 17 de fevereiro de 2017. Disponível em: <http://www.planalto.gov.br/ccivil_03/_ ato2015-2018/2017/lei/L13415.htm>. Acesso em: 29 fev. 2019
} 
Sobre as aprendizagens essenciais que crianças e jovens devem desenvolver ao longo das etapas e séries da educação básica, o documento apresenta, por exemplo, uma relação entre Astronomia e Cultura como uma das competências específicas na área de Ciências da Natureza para o 9a ano do Ensino Fundamental II: Relacionar diferentes leituras do céu e explicações sobre a origem da Terra, do Sol ou do Sistema Solar às necessidades de distintas culturas (agricultura, caça, mito, orientação espacial e temporal etc.) (BRASIL, 2018, p.303)

Ainda em referência à pluralidade cultural nos documentos oficiais brasileiros, a Lei de Diretrizes e Bases da Educação Nacional (LDB - Lei no 9.394), aprovada em dezembro de 1996, tem em seu Art. 3ํa consideração da diversidade étnico-racial a ser um dos princípios básicos da educação do Brasil, incluída pela Lei nำ12.796 de 2013.

No ano de 2008, a Lei federal № 11.645 é incluída na LDB, alterando o Art. 26A, que torna-se obrigatório no ensino fundamental e médio, o estudo de história e cultura afro-brasileira e indígena, complementada pelos parágrafos:

"§ 10 O conteúdo programático a que se refere este artigo incluirá diversos aspectos da história e da cultura que caracterizam a formação da população brasileira, a partir desses dois grupos étnicos, tais como o estudo da história da África e dos africanos, a luta dos negros e dos povos indígenas no Brasil, a cultura negra e indígena brasileira e o negro e o índio na formação da sociedade nacional, resgatando as suas contribuições nas áreas social, econômica e política, pertinentes à história do Brasil.

$\S 20$ Os conteúdos referentes à história e cultura afro-brasileira e dos povos indígenas brasileiros serão ministrados no âmbito de todo o currículo escolar, em especial nas áreas de educação artística e de literatura e história brasileiras. " (BRASIL, 2017, p.21)

Apesar desta lei dar ênfase na inclusão dos conteúdos de origem afro-brasileira e indígena nas áreas de artes, literatura e história, podemos fazer um paralelo ao que a Base Nacional Comum Curricular traz para a pluralidade cultural na área das ciências naturais. Com isso, pode-se dizer que trazer à tona as relações dos indígenas com o cosmos, torna-se importante para que esses povos possam ter visibilidade e reconhecimento de seus conhecimentos, como previsto na Declaração Universal dos Direitos dos Povos Indígenas:

"§11 - Os povos indígenas têm o direito à dignidade e à diversidade de suas culturas, histórias, tradições e aspirações refletidas em todas as formas de educação e informação públicas. Os Estados tomarão medidas efetivas para eliminar os preconceitos e fomentar a tolerância, entendimento e boas relações. " (BRASIL, 2014) 


\title{
1.4. Diferentes abordagens do Multiculturalismo
}

Para compreender a importância da presença do multiculturalismo na escola, é fundamental conhecer algumas de suas múltiplas concepções. Para isso, usar-se-á multiculturalismo proposto por Candau (2013) fazendo-se um paralelo com as propostas que envolvem os temas multiculturais expostas por Peter McLaren ${ }^{3}$. A urgência do tema é mostrada por Candau (2013) por meio de uma contextualização das relações entre escola e cultura e apresenta, de modo mais detalhado, as facetas do multiculturalismo, começando por trazer a importância de um despertar de consciência da questão multicultural no Brasil, principalmente no que diz respeito aos grupos indígenas e afrodescendentes, estando diretamente relacionado a nossa bagagem histórica-social-cultural.

\begin{abstract}
"Nossa formação histórica está marcada pela eliminação física do "outro" ou por sua escravidão, que também é uma forma violenta de negação de sua alteridade. Os processos de negação do "outro" também se dão no plano das representações e do imaginário social. Neste sentido, o debate multicultural na América Latina nos coloca diante da nossa própria formação histórica, da pergunta sobre como nos construímos socioculturalmente, o que negamos e silenciamos, o que afirmamos, valorizamos e integramos na cultura hegemônica. " (CANDAU, 2013, p.17)
\end{abstract}

É nessa relação com nossas mais profundas raízes que faz-se urgente uma compreensão do que se trata o multiculturalismo com o intuito de praticá-lo, não só nas relações sociais mas, principalmente, dentro da escola.

Por essa razão, Candau (2013) apresenta algumas de suas abordagens sobre o tema e, a priori, destaca duas perspectivas fundamentais que norteiam essa compreensão: uma descritiva e outra propositiva.

Para a afirmação descritiva, a autora mostra o multiculturalismo como uma das características da sociedade contemporânea, onde suas configurações dependem dos aspectos socioculturais, históricos e políticos e, por essa razão, o multiculturalismo na sociedade brasileira difere daquele presente em lugares europeus ou norte-americanos. Trata-se da compreensão das construções que envolvem as configurações culturais de cada ambiente específico.

\footnotetext{
${ }^{3}$ Professor associado da Graduate School of Education and Information Studies na Universidade da Califórnia em Los Angeles e um dos maiores autores da pedagogia crítica da atualidade.
} 
A segunda perspectiva exposta pela autora (propositiva), compreende 0 multiculturalismo como uma forma de intervir e atuar na sociedade e não somente como um dado encontrado no mundo atual. Neste caso, o multiculturalismo tem papel de projeto político-cultural, onde deve-se trabalhar as relações culturais de uma sociedade, além de conceber políticas públicas em viés da democracia. Ainda dentro desta perspectiva, Candau refere-se à mais três abordagens multiculturais que, segundo a autora, estão na base das diversas propostas sobre multiculturalismo. São elas: multiculturalismo assimilacionista, diferencialista e multiculturalismo interativo ou também intercultural.

O multiculturalismo assimilacionista apresenta um caráter descritivo da sociedade atual em que vivemos. Com isso, a abordagem assimilacionista parte da ideia de uma sociedade multicultural onde existem desigualdades de oportunidade para todos que a compõem e, com isso, procura integrar os grupos mais discriminados por seus valores, conhecimentos e sua posição social à cultura dominante. Nessa perspectiva, não há, portanto, questionamentos acerca da posição privilegiada que é dada a uma certa cultura. O problema desta concepção é que legitima-se uma cultura hegemônica e deslegitima os saberes, crenças, valores e dialetos que fazem parte de grupos menos valorizados socialmente.

Esta perspectiva assimilacionista faz um paralelo, ainda que sucinto, com o que Peter McLaren (1997) chama de multiculturalismo conservador, em que os grupos étnicos são caracterizados como "acréscimos" à cultura dominante, e ainda complementa "um pré-requisito para "juntar-se à turma" é desnudar-se, desracializarse e despir-se de sua própria cultura. " (MCLAREN, 1997, p.115), ressaltando o quanto a perspectiva multicultural de natureza assimilacionista é problemática.

Retomando aos conceitos definidos por Candau (2013), a abordagem diferencialista propõe que sejam consideradas as diferentes características de cada grupo de acordo com sua historicidade, suas raízes e sua cultura, defendendo a necessidade de espaços onde esses grupos possam se manifestar de forma a manter suas matrizes culturais. O problema desta visão é que, apesar de haver um reconhecimento das diferenças, na sociedade atual, essa concepção tende a criação de um "apartheid sociocultural" segundo a autora.

Ambas as abordagens, tanto a assimilacionista, quanto a diferencialista encontram-se, segundo Candau, fortemente presentes nas sociedades contemporâneas e, por essa razão, busca-se uma terceira concepção, que é definida 
como multiculturalismo interativo ou intercultural. Nesta abordagem, a ideia central é a interculturalidade que visa, através do diálogo, um intercâmbio cultural de forma a se construir uma sociedade mais democrática, inclusiva e plural. Desta forma, a perspectiva intercultural seria aquela capaz de promover uma educação para o reconhecimento do "outro" e para o diálogo entre os diferentes grupos culturais e sociais (CANDAU, 2013).

Usando as palavras de Freire (2016):

\begin{abstract}
"É preciso reenfatizar que a multiculturalidade como fenômeno que implica a convivência num mesmo espaço de diferentes culturas não é algo natural e espontâneo. É uma criação histórica que implica decisão, vontade pública, mobilização, organização de cada grupo cultural com vistas a fins comuns. Que demanda, portanto, certa prática educativa coerente com esses objetivos. Que demanda uma nova ética fundada no respeito às diferenças. " (FREIRE, 2019, p.216)
\end{abstract}

\title{
1.4.1. O multiculturalismo intercultural
}

Considerando as propostas apresentadas anteriormente, vemos a necessidade de explorar a perspectiva que defendemos neste trabalho, que é denominado por Candau (2013) como multiculturalismo interativo ou intercultural.

Essa perspectiva vai em confronto as visões assimilacionistas e diferencialistas pois valoriza as riquezas da diferença dos diversos grupos culturais, sem a necessidade de processos radicais de afirmação de identidades. No contexto intercultural proposto por Candau (2013), temos as culturas como um processo, que se constrói e se reconstrói, sem romper com as raízes profundas e a historicidade de cada uma delas, mas com um não engessamento das pessoas. Trata-se de uma cultura em constante reelaboração. Além disso, considera-se que as relações culturais estão entrelaçadas com as questões de poder, de preconceitos e relações duramente hierarquizadas, tornando esta dimensão, um desafio a ser cumprido, não só no nosso convívio diário de respeito, mas principalmente no contexto escolar.

Trazendo novamente as ideias de Peter McLaren à tona, podemos sincronizar esta perspectiva de Candau com o multiculturalismo crítico proposto pelo autor. Ambas as visões compartilham de que as culturas são construídas a partir de aspectos sociais, econômicos, históricos e ideológicos e, para além disso, ambas suscitam a necessidade de atuação e intervenção na dinâmica da sociedade em viés da democracia. Para McLaren: "O multiculturalismo sem uma agenda política de 
transformação pode apenas ser outra forma de acomodação de uma ordem social maior." (MCLAREN, 1997, p.122)

Olhando a proposta do multiculturalismo intercultural mais a fundo, é necessário destacar que essa perspectiva articula as políticas de identidade e de igualdade, valoriza a importância do diálogo e reconhecimento do "outro", que possibilita a construção de uma formação mais democrática e inclusiva e, por isso, é de grande importância para ser levada para além dos convívios sociais, tornando tema essencial de ser levado à escola.

Essa visão multicultural também proporciona o diálogo entre conhecimentos e saberes de diversas culturas. Candau (2011) salienta que, apesar de muitos autores usarem ambos os termos como sinônimos, deve-se diferenciá-los de modo a considerar que haja um incentivo de diálogo entre os diferentes conhecimentos e saberes.

\begin{abstract}
"O que chamamos conhecimentos estaria constituído por conceitos, idéias e reflexões sistemáticas que guardam vínculos com as diferentes ciências. Estes conhecimentos tendem a ser considerados universais e científicos, assim como a apresentar um caráter monocultural. Quanto aos saberes, são produções dos diferentes grupos socioculturais, estão referidos às suas práticas cotidianas, tradições e visões de mundo. São concebidos como particulares e assistemáticos. Considero que o mais relevante, deixando aberta esta discussão, é considerar a existência de diferentes saberes e conhecimentos e descartar qualquer tentativa de hierarquizá-los. " (CANDAU, 2011, p.247)
\end{abstract}

Nesse sentido, o multiculturalismo intercultural trabalha com essa tensão, assumindo os conflitos e lidando com essas relações, de forma a sempre manter o intercâmbio cultural. Somente desta forma dá-se voz aos grupos menos valorizados socialmente, que são discriminados pelos saberes e conhecimentos que possuem e por terem que lidar a homogeneização do que se chega a escola. Candau ainda salienta que essa perspectiva deve balancear e saber lidar entre universalismo e relativismo no plano epistemológico e ético, considerando toda a complexidade da realidade dessa relação.

Dialogando com Catherine Walsh (2001, apud CANDAU, 2013, p.23-24) no que a autora promove como interculturalidade, temos:

- Um processo dinâmico e permanente de relação, comunicação e aprendizagem entre culturas em condições de respeito, legitimidade mútua, simetria e igualdade. 
- Um intercâmbio que se constrói entre pessoas, conhecimentos, saberes e práticas culturalmente diferentes, buscando desenvolver um novo sentido entre elas na sua diferença.

- Um espaço de negociação e de tradução onde as desigualdades sociais, econômicas e políticas, e as relações e os conflitos de poder da sociedade não são mantidos ocultos e sim reconhecidos e confrontados.

- Uma tarefa social e política que interpela ao conjunto da sociedade, que parte de práticas e ações sociais concretas e conscientes e tenta criar modos de responsabilidade e solidariedade.

- Uma meta a alcançar.

Considerando as concepções adotadas por Candau (2013) no que diz respeito à proposta intercultural apresentada, seu esquema teórico será utilizado como norteador e referencial de análise dos materiais ao longo deste trabalho. 


\title{
CAPÍTULO 2: MULTICULTURALISMO E ENSINO DE CIÊNCIAS
}

\author{
"Hasta que los leones tengan sus \\ propios historiadores, las historias de \\ cacería seguirán glorificando al \\ cazador." \\ Provérbio Africano
}

A proposta deste capítulo consiste em apresentar a importância de se conhecer e valorizar os conhecimentos advindos das diversas culturas e quais os ganhos da relação entre ciência e cultura para o ensino de Ciências. Para isso, a primeira parte deste capítulo se preocupa em apresentar um panorama sobre as diferentes colonialidades, a importância das epistemologias do "SUL" e seus vínculos com o ensino de ciências.

Apresenta-se também a concepção de Astronomia Cultural que defendemos neste trabalho, que é a leitura e compreensão do céu por diversos grupos culturais, em que se leva em conta suas manifestações sociais que envolvem todo o cosmos.

Além disso, a última parte do capítulo se concentra em apresentar uma revisão bibliográfica sobre o multiculturalismo e a astronomia cultural presente em revistas, periódicos e eventos da área de ensino de ciências e de física. Para esta análise, contamos com o referencial metodológico da análise de conteúdo proposto por Moraes (1999), em que foi possível obter um cenário no qual esta pesquisa está inserida. Desta revisão bibliográfica foram selecionados 31 trabalhos e destes, somente 25 foram analisados na íntegra e agrupados em categorias como proposto pela metodologia escolhida.

\subsection{Ciência e Cultura: a valorização dos múltiplos conhecimentos no contexto do ensino de ciências}

Promover a ciência como uma construção humana, que depende de relações históricas e culturais têm sido uma preocupação dos pesquisadores da área de ensino de ciências, uma vez que, este viés - de tratar a ciência como cultura - poderia minimizar a supervalorização desse conhecimento em função da deslegitimação de outras formas de interpretar o mundo. Isso se torna ainda mais difícil com as novas políticas educacionais e com o crescimento do pensamento neoliberal, em que, cada vez mais, as escolas passam por uma privação de conhecimentos e são obrigadas a 
trazer resultados e fatores de impacto, tornando-a um lugar de difícil abertura para uma educação para a diversidade.

Nos casos dos países colonizados, por exemplo, a escola pouco introduz os conhecimentos e cultura advindos dos grupos locais, tornando-a uma instituição organizada para o benefício de conversão dos colonizadores. (ALBUQUERQUE, 2010; SANTIAGO; AKKARI; MARQUES, 2013)

Para Catherine Walsh (2009), o ponto chave para entender a interculturalidade no contexto em que estão fortemente presentes as relações de poder, de mercado e capital que permeiam todo o cenário político, é a compreensão do processo histórico da construção da ideia de "raça" como classificação e controle social. Outro aspecto apontado pela autora é o desenvolvimento do capitalismo mundial, o qual tem papel essencial na constituição histórica de toda a América e que, acaba por corroborar para uma assimetria social.

Claro que a ciência moderna reconheceu a existência do colonialismo histórico, baseado na ocupação territorial estrangeira, mas não reconheceu o colonialismo enquanto forma de sociabilidade que é a parte integrante da dominação capitalista e patriarcal e que, por isso, não terminou quando o colonialismo histórico chegou ao fim. (SANTOS, 2019, p.41)

Com isso, Walsh apresenta quatro dimensões da colonialidade que afirmam "o lugar central da raça, do racismo e da racialização como elementos constitutivos e fundantes das relações de dominação. " (WALSH, 2009, p.16). Desta maneira, a raça acaba por ser elemento central para compreendermos a complexidade das relações colonizador-colonizado que permeiam a nossa história, uma vez que, na medida em que essas relações se configuram em um cenário de dominação, as identidades passam a ocupar posições, lugares e papel social (QUIJANO, 2005).

A primeira dimensão abordada pela autora é a colonialidade do poder (QUIJANO, 2005) que estabelece uma hierarquia racial fixa na sociedade, onde apaga-se as diferenças culturais e históricas, classificando algumas identidades culturais como negativas e, partindo dessa forma social - já naturalizada - que a autora apresenta a colonialidade do ser como categorias binárias presentes no modelo neoliberal vigente - como exemplos, Walsh (2009) nos apresenta a relação de superioridade/inferioridade, oriente/ocidente, humanização/desumanização. A terceira concepção é a colonialidade do saber, que trata o eurocentrismo como a única perspectiva válida e, por isso, hegemônica. 
Antes de apresentar a quarta perspectiva, vale ressaltar que atualmente a subordinação, exclusão e colonização escondem-se por meio de um discurso multicultural neoliberal, em que a colonialidade do saber se reacomoda/se adapta aos modelos neoliberais, dando uma falsa impressão de que os problemas dessa relação de superioridade tenham se resolvido. Dessa forma, operam em uma logística multicultural que se incorpora a diversidade na medida em que se esvazia o seu real significado (ZIZEK,1998 apud WALSH, 2009), podendo se assemelhar com 0 multiculturalismo assimilacionista proposto por Candau (2013) em que se inclui o "diferente" à lógica hegemônica sem o devido respeito e valorização à diversidade. Assim, segundo Walsh, o multiculturalismo posto desta forma, além de ser uma maneira de controle social, faz com que ocorra uma nova estratégia de dominação

\begin{abstract}
que ofusca e mantém, ao mesmo tempo, a diferença colonial através da retórica discursiva do multiculturalismo e sua ferramenta conceitual, a interculturalidade "funcional", entendida de maneira integracionista. Essa retórica e ferramenta não apontam para a criação de sociedades mais equitativas e igualitárias, mas para o controle do conflito étnico e a conservação da estabilidade social, com o fim de impulsionar os imperativos econômicos do modelo neoliberal de acumulação capitalista, agora "incluindo" os grupos historicamente excluídos. (WALSH, 2009, p. 16)
\end{abstract}

Tratando-se da quarta abordagem proposta, temos a colonialidade cosmogônica ou colonialidade da mãe natureza que é relacionada à "força vital-mágico-espiritual da existência das comunidades afrodescendentes e indígenas" (Ibidem,p. 15) vinculando as relações espirituais como pagãs e/ou primitivas, pretendendo-se desta forma, anular os sistemas de vida, exterminando os processos de civilização desses grupos.

Essas dimensões das diversas colonizações tem impacto nos conhecimentos que chegam e são valorizados nas escolas. A interculturalidade que chega nessa instituição é a chamada Interculturalidade Funcional (TUBINO, 2005) que não questiona as "regras do jogo", é compatível com o modelo capitalista e não trata da assimetria social e cultural presente. E, por essa razão, o projeto e processo que vai no sentido contra hegemônico é a Interculturalidade crítica (WALSH, 2009) - proposta que vai no mesmo sentido do multiculturalismo intercultural já apresentado. Temos essa vertente da interculturalidade como prática-política, que debate as diferenças em níveis mais profundos, ultrapassando a diversidade étnico-cultural e partindo do 
problema dos poderes envolvidos na sociedade, nos padrões de racialização e nas diferenças advindas das colonizações.

Para além dos entraves causados pelas diversas colonizações, existe também uma problemática no que diz respeito à nossa localização no mundo: o Sul. Os padrões e entendimentos sobre o que está "acima"/"abaixo" do globo faz uma correlação com tudo o que é valorizado ao longo da história - povos, epistemologias, etc. Ou seja, a história das lutas de determinados povos e conhecimentos que não são advindos do ocidente-europeu, são facilmente desqualificados pelo restante do mundo.

Paulo Freire (2018) na obra "Pedagogia da Tolerância", em um capítulo sobre "Viver é recriar: um diálogo sobre a Educação Indígena", ressalta essa história negada dos povos indígenas e afrodescendentes, que até hoje, lutam por um movimento de conscientização de novo reaprender de suas histórias.

A História já está cheia disso, se repete em todo lugar. Não é por acaso que o branco colonizador da África tenha tentado convencer o africano de que o africano não tinha História, antes que o branco tivesse chegado. (...) O branco trouxe a História na mão, e a História é sua, e deu de presente, porque "quer bem" ao desgraçado do negro, a História do branco. (FREIRE, 2018, p.29)

Todavia, há de se reconhecer que na Europa, grandes pessoas tiveram papel essencial no que diz respeito ao desenvolvimento do pensamento científico, filosófico, por exemplo, mas é necessário que também possamos ampliar o nosso campo de visão para outras tantas filosofias, modo de ser e pensamento científico. Nas palavras de Boaventura de Sousa Santos (2016, p.28):

\footnotetext{
Não se trata, pois, de demonizar o pensamento europeu ou a ciência moderna europeia, mas de reconhecer as suas incompletudes. Do mesmo modo, o objetivo não é romantizar as inovações do Sul (...), isto é, reconhecer experiências e conhecimentos invisibilizados e desvalorizados pelo pensamento colonial para pensar o futuro a partir de um presente dilatado (...). (grifo nosso)
}

Assim, valorizar as diversas maneiras de ver o mundo por meio de um projeto intercultural, pode contribuir para a superação dos epistemicídios - "destruição maciça de experiências e conhecimentos subordinados, considerados inadequados para servir o projeto colonial” (SANTOS, 2014 apud Ibidem, 2016, p.26) - que estão enraizados na sociedade moderna. 
Com relação aos sistemas escolares - e para além dele - existe uma dificuldade que é a de mudança de referencial para a valorização dessas epistemologias que emergem do Sul. Nossas orientações - em todas as áreas, seja no ensino das ciências humanas ou naturais - têm como referência tudo aquilo que pode nos nortear. Campos (1991) nos apresenta um "Sulear-se" como sendo um ato que vai para além de simplesmente usarmos como orientação espacial o Sul, mas de estarmos abertos para os conhecimentos que daqui provêm.

\begin{abstract}
Em qualquer referencial local de observação, o Sol nascente do lado do oriente permite a ORIENTação. No hemisfério norte, a Estrela Polar, Polaris, permite o NORTEamento. No hemisfério sul, o Cruzeiro do Sul permite o "SULeamento".Apesar disto, em nossas escolas, continua a ser ensinada a regra prática do norte, ou seja, com a mão direita para o lado do nascente (leste), tem-se a esquerda o oeste, na frente o norte e atrás o sul, com essa pseudo-regra-prática dispomos de um esquema corporal que, à noite, nos deixa de costas para o Cruzeiro do Sul, a constelação fundamental para o ato de "SULear-se". Não seria melhor usarmos a mão esquerda apontada para o lado do oriente? (...) Com o polo norte para cima, o conhecimento "escorre" e nós o engolimos sem conferir com o contexto local. (CAMPOS, 1991, p.1)
\end{abstract}

Freire (2019) em suas notas, faz uma provocação acerca dessa ideologia que está enraizada em nosso vocabulário:

\begin{abstract}
"Assim, me alongo nas observações-denúncias do prof. Marcio Campos perguntando-nos com a intenção de provocar-nos a reflexão: "virar as costas" ou virar "de costas" ou nos deixar de costas para o Cruzeiro do Sul - signo da bandeira, símbolo brasileiro, ponto de referência para nós - não seria uma atitude de indiferença, de menosprezo, de desdém para com as nossas próprias possibilidades de construção local de um saber que seja nosso, para com as coisas locais e concretamente nossas?" (FREIRE, 2019, p.297)
\end{abstract}

São destas palavras-indagações que vemos a necessidade de se firmar 0 vínculo entre os conhecimentos já tradicionais da escola com aqueles que emergem da nossa cultura, do nosso povo. Fazendo um recorte para a área do ensino de ciências da natureza, por ser o contexto em que essa pesquisa se insere, vemos ainda mais a importância de se "virar face ao sul", uma vez que, além das questões já citadas, o próprio livro didático foi um dos elementos de difusão de racismo no cenário brasileiro, por apresentar estereótipos e estigmatizar os personagens negros e indígenas (SANTIAGO; AKKARI; MARQUES, 2013). São por essas razões, de busca à transcendência perante as epistemologias e seus vínculos com as diversas culturas que reafirmamos a importância da interculturalidade nos processos escolares. 
Falar de uma política epistêmica da interculturalidade, mas também de epistemologias políticas e críticas, poderia servir, no campo educativo, para colocar os debates em torno da interculturalidade em outro nível, transpassando seu fundo enraizado na diversidade étnico-cultural e focalizando o problema da "ciência" em si; isto é, a maneira através da qual a ciência, como um dos fundamentos centrais do projeto da modernidade/colonialidade, contribuiu de forma vital para 0 estabelecimento e manutenção da histórica e atual ordem hierárquica racial, na qual os brancos, e especialmente os homens brancos europeus, permanecem em cima. Permite considerar a construção de novos marcos epistemológicos que pluralizam, problematizam e desafiam a noção de um pensamento e conhecimento totalitários, únicos e universais, partindo de uma política e ética que sempre mantêm como presente as relações do poder às quais foram submetidos estes conhecimentos. Assim, alenta novos processos, práticas e estratégias de intervenção intelectual que poderiam incluir, entre outras, a revitalização, revalorização e aplicação dos saberes ancestrais, não como algo ligado a uma localidade e temporalidade do passado, mas como conhecimentos que têm contemporaneidade para criticamente ler 0 mundo, e para compreender, (re) aprender e atuar no presente (WALSH, 2009, p. 24-25) (grifo nosso)

Todavia, apesar da discussão entre ciência e cultura estar crescendo, é frequente os professores ensinarem ciências de modo não tradicional - tentando incorporar práticas diferenciadas, envolver o diálogo, experimentar outras atividades dentro e fora de sala de aula - mas mantêm o modo tradicional de não discutirem o que é ciência, suas possibilidades, limitações inerentes, sua história e suas relações com a cultura e assuntos humanos (JAFELICE, 2002). Por isso, a dimensão cultural na área de astronomia pode auxiliar no empreendimento de trazer a interculturalidade à tona, pois é uma forma de compreender as diversas visões de mundo junto aos contextos sociais e culturais que envolvem o conhecimento do céu.

\subsubsection{O ensino de Astronomia Cultural no ensino de ciências}

De acordo com SANTOS (2000 apud JAFELICE, 2015) a "ciência [...] é uma das fontes de poder do pensamento único" que se encontra fortemente presente na globalização capitalista, excluindo a multiplicidade das contribuições das diversas epistemologias, como as brasileiras. Quando abordamos os conhecimentos advindos de outras matrizes que não seja a científica ocidental tradicional, logo se coloca em pauta as comparações de veracidade (ou não) de cada uma. Por isso, devemos deixar claro $O$ que se almeja quando se traz à tona para as escolas outros "etnoconhecimentos" (JAFELICE, 2015) para 
Não confundir esta posição com uma atitude anticientífica. Aquela visa apenas recolocar a ciência no seu devido lugar, pois esta costuma ser "considerada [...] infalível" (Ibid.), o que não corresponde ao observado. (op.cit)

A Astronomia Cultural é um campo acadêmico relativamente novo, ainda que possa ter uma longa tradição. De acordo com Lima et al (2014), os primeiros trabalhos quantitativos na área de astronomia cultural surgiram nas últimas décadas do século dezenove, com trabalhos de investigação de alinhamentos astronômicos em sítios arqueológicos, tendo como trabalho pioneiro, os estudos sobre Stonehenge em 1880.

O termo, "Astronomia Cultural" cunhado na década 1990 (IWANISZEWSKI, 1990, 1991; RUGGLES; SAUNDERS, 1990 apud LÓPEZ, 2015), é compreendido como sendo um conjunto de manifestações socioculturais e saberes de diversos grupos em relação aos elementos que constituem o céu. Assim, analisa-se os modos que diversas sociedades constroem seus conhecimentos e práticas sobre os corpos celestes e seus fenômenos. Desta maneira, ressaltamos que a astronomia cultural é um conhecimento difundido por pesquisadores provenientes da academia, que estuda sobre o conhecimento que é elaborado por determinados grupos e/ou populações a partir de suas relações específicas com o cosmos. Assim, devemos tomar certa cautela para não assumir que determinadas culturas produzem "astronomia", sendo esta, a opção escolhida pela cultura ocidental para estudar as coisas do céu. (LÓPEZ, 2015; LIMA ET AL, 2014; JAFELICE, 2009).

Neste trabalho, quando falamos em "astronomia", falamos em uma concepção mais ampla do que a comumente usada no meio acadêmico. Trazemos uma ideia de que os saberes sobre o céu incluem uma perspectiva mais completa, incorporando diversas outras áreas do saber, de forma a se obter uma astronomia mais plural, com um "afastamento do etnocentrismo cabedal teórico-metodológico fundamental" (MELLO, SOARES, KERBER, 2011)

\footnotetext{
Hoje, se se quer abordar astronomia - ou melhor, uma relação autêntica com "os céus"- desde uma perspectiva antropológica, que englobe elementos que desde sempre estiveram naturalmente contemplados pelo que se entendia por astronomia - como conteúdos típicos de história, filosofia, religião, etc. então convém deixar claro que se está interessado em astronomia cultural. " (JAFELICE, 2010, p. 249)
}

Desta forma, o multiculturalismo se intersecta com a astronomia cultural, de forma a mostrar a importância de se levar ambos para dentro do ensino de ciências. 
Isso é possível pois, apresentar os distintos céus é uma maneira de afastar o etnocentrismo e promover o exercício de respeito e valorização do conhecimento de grupos que são menos valorizados, levando em consideração que cada sociedade interpreta e lê o mundo de uma maneira diversa, a partir de suas próprias tradições e saberes.

Nesse sentido, não há visão melhor, ou privilegiada, apenas visões distintas. (...) nas sociedades de tradição científica ainda se encontra um sistema valorativo mediante o qual a forma de construir conhecimentos, reconhecida como válida por nosso sistema cultural, é vista por muitos como epistemologicamente superior. (LIMA ET AL, 2014, p.93)

\subsection{Astronomia Cultural nas pesquisas em Ensino de Ciências: um panorama}

Esta seção tem por intenção apresentar uma revisão bibliográfica acerca dos temas que permeiam a pesquisa, de maneira a compreender como a Astronomia Cultural está presente em publicações acadêmicas, buscando observar de que forma esse tema vem ganhando espaço nas pesquisas e de quais maneiras ele aparece. Assim, buscamos verificar nos trabalhos, se há valorização da diversidade cultural, presença de propostas didáticas e como estas são realizadas, entre outras. Acreditamos que seja necessário este tipo de mapeamento para termos uma visão geral do contexto em que nossa pesquisa está inserida, acarretando numa maior compreensão da temática.

Para isso, selecionamos artigos publicados em quatro eventos nacionais e um evento internacional entre os anos de 2009 e 2019, que trazem os trabalhos mais novos relacionados ao ensino de Astronomia, de Física e Ciências com interfaces no ramo da cultura, interculturalidade e multiculturalismo. Os eventos são:

- Encontro Nacional de Pesquisa em Ensino de Ciências (ENPEC)

- Encontro de Pesquisa em Ensino de Física (EPEF)

- Simpósio Nacional de Ensino de Física (SNEF)

- Simpósio Nacional de Educação em Astronomia (SNEA)

- Simpósio Internacional de Educação em Astronomia e Astrobiologia International Symposium on Education in Astronomy and Astrobiology. (ISE2A)

Para que possamos analisar de maneira mais íntegra como as pesquisas que relacionam a astronomia e cultura aparecem no cenário mundial, fez-se também uma 
revisão de dois periódicos internacionais: Revista Latino-Americana de Educação em Astronomia (RELEA) e Journal of Astronomy in Culture.

Acreditamos que, através do resultado desta pesquisa nos periódicos, possamos compreender como este tema vem sendo tratado não só em nosso país, mas a proporção e o espaço que a temática vem ganhando com o passar do tempo em outros lugares do mundo, principalmente no que diz respeito à América Latina, uma vez que, a diversidade cultural e o multiculturalismo são temas atuais que vem fazendo parte das pesquisas acadêmicas nas últimas décadas.

A Revista Latino-americana de Educação em Astronomia (RELEA) apresenta suas publicações em suporte digital, contendo artigos, ensaios teóricos e resenhas no campo da educação em Astronomia em toda a América Latina. De acordo com os interesses da pesquisa, analisamos este periódico em todas as suas edições, que permeiam o período do ano de 2004 até 2018, totalizando 28 obras encontradas.

Já o periódico da Sociedade Internacional de Arqueoastronomia e Astronomia na Cultura (International Society for Archaeoastronomy and Astronomy in Culture $\mathrm{ISAAC}^{4}$ ) possui, até o momento, somente uma edição e foi publicado por meio virtual e foi explorado também em sua totalidade. Nesta edição referente ao ano de 2016 , foi encontrado um capítulo que aborda os conhecimentos da astronomia cultural indígena produzidos na América do Sul.

Adiantamos que, mesmo com o crescimento de temas que envolvem as múltiplas relações com o céu na área de ensino de ciências, poucos trabalhos foram identificados com a temática de interesse da pesquisa. Além disso, destacamos que ainda que o trabalho tenha interface das temáticas das ciências (Física, Astronomia e Ciências) com as temáticas culturais (interculturalidade, cultura e multiculturalismo), fez-se uma peneira para aqueles trabalhos que levassem em conta abordagens na perspectiva do conhecimento indígena e a obrigatoriedade da Lei 11.645/08, por conta da valorização do conhecimento local, ficando de fora as pesquisas que abordem, por exemplo, o conhecimento do céu por outros povos, como os egípcios.

\footnotetext{
${ }^{4}$ Fundada em 1996, este grupo promove o desenvolvimento e a pesquisa acadêmica na área de astronomia cultural por meio de publicações e projetos interdisciplinares nos Estados Unidos. Para isso, o ISAAC publica seus trabalhos no Jornal de Astronomia na Cultura, mantido e hospedado na Universidade da Califórnia desde 2016.
} 


\subsubsection{Metodologias}

As pesquisas de caráter qualitativo têm crescido no que se refere a trabalhos na área de educação. Esta pesquisa também utiliza esse tipo de abordagem, que tem por característica uma metodologia que salienta a indução do pesquisador, as descrições, estudos das percepções pessoais, etc (BOGDAN, BIKLEN, 1994).

Para esse tipo de investigação, as questões a serem investigadas se formam não por meio de hipóteses e análises com definições operacionais, mas investigam os fenômenos levando em consideração toda a complexidade que envolve uma pesquisa em educação - pessoas, ambiente, diálogo. Como características principais, Bogdan e Biklen (1994) apresentam cinco aspectos da pesquisa qualitativa que, de maneira sucinta, ressaltam levar em consideração os ambientes da pesquisa como sendo um instrumento essencial (isso no caso em que são realizadas em escolas, por exemplo); os dados deste tipo de pesquisa são descritivos - imagens e palavras -, em que os resultados são citações com base nos dados recolhidos; o processo é de maior interesse do que o resultado final; a pesquisa qualitativa vai ganhando forma na medida em que os dados são recolhidos e explorados de maneira indutiva; e tem um significado de extrema importância.

No que se refere à análise documental utilizada nessa pesquisa, Ludke e André (1986) a adjetivam como "uma técnica valiosa de abordagem" (LUDKE; ANDRE, 1986, p. 38) e caracterizam como documentos à serem analisados, as leis, normas, jornais, livros, pareceres, entre outras.

Guba e Lincoln (1981 apud LUDKE; ANDRÉ, 1986) destacam que a riqueza dos documentos quando se pretende fazer uma análise de forma qualitativa é que são fontes inesgotáveis, estáveis e ricas, que nos fornece informações de um determinado contexto.

\footnotetext{
Persistindo ao longo do tempo, os documentos podem ser consultados várias vezes e inclusive servir de base a diferentes estudos, o que dá mais estabilidade aos resultados obtidos. (...) [são] uma fonte poderosa de onde podem ser retiradas evidências que fundamentam afirmações e declarações do pesquisador. Representam uma fonte "natural" de informação. (Ibidem, p.39)
}

Para a revisão bibliográfica, utilizou-se como referencial metodológico os conceitos da análise de conteúdo (MORAES, 1999) que tem por base interpretar os 
conteúdos de qualquer classe de documentos e textos de forma a compreender de maneira mais profunda seus significados. No que concerne como fundamento desse tipo de análise, a mesma auxilia o pesquisador a interpretar as mensagens de um texto e/ou documento para atingir seu nível mais profundo do que uma simples leitura. Para isso, os dados a serem analisados chegam em estado bruto a fim de serem processados pelo pesquisador, para se chegar à uma compreensão, interpretação e interferência do produto. Vale evidenciar, assim como ressalta o autor, que a interpretação de qualquer material tem relação direta com a interpretação pessoal do pesquisador e, por essa razão, não teríamos uma interpretação neutra no processo de análise.

Moraes em seu texto nos diz que é possível categorizar alguns possíveis objetivos utilizando a análise de conteúdo, em que são levados em consideração os aspectos intrínsecos da matéria prima desse tipo de análise. Para isso, o autor se baseia em seis categorias definidas originalmente por Laswell (s.d). que tem por principal característica a comunicação do contexto que se referem às pesquisas $e$ suas pretensões. Destacamos aqui, três destas seis categorias que têm mais congruência com esta pesquisa:

\begin{abstract}
"Quando uma pesquisa utilizando análise de conteúdo se dirige à questão para dizer o quê? o estudo se direciona para as características da mensagem propriamente dita, seu valor informacional, as palavras, argumentos e idéias nela expressos. É o que constitui uma análise temática. (...)

Quando os objetivos da análise de direcionam ao "como?" o pesquisador estará voltado à forma como a comunicação se processa, seus códigos, seu estilo, a estrutura da linguagem e outras características do meio pelo qual a mensagem é transmitida.

Ao direcionar seu estudo para o "com que finalidade?" o pesquisador se questionará sobre os objetivos de uma dada comunicação, sejam explícitos ou implícitos. Analisar a finalidade é novamente orientar-se para o emissor, mas no sentido de captar as finalidades com que emite uma determinada mensagem, sejam eles manifestos ou ocultos." (MORAES, 1999, p.4) (grifo do autor)
\end{abstract}

No que diz respeito à metodologia mais específica proposta pelo autor, nos é apresentado cinco etapas que compõem esse processo metodológico.

A primeira etapa denominada como "preparação das informações" consiste em identificar as amostras e fazer uma peneira daqueles materiais que serão efetivamente analisados por condizerem com os objetivos da pesquisa, tornando-os essenciais e parte central do trabalho de pesquisa. 
Em seguida, passa-se para a "unitarização" que consiste em reler cuidadosamente os materiais que foram selecionados na primeira etapa para criar as "unidades de significado" ou "unidades de análise". É neste momento que o pesquisador faz o recorte das principais partes dos materiais que foram selecionados, para que, posteriormente, sejam submetidos à categorização na continuação da análise. Neste processo, a fragmentação dos pontos importantes do material acarreta, necessariamente, na perda de parte da informação do material analisado e, por essa razão, quanto mais fragmentado é o texto, mais é exigido no pesquisador para conectar esse material à parte da pesquisa como um todo.

Para a terceira fase, Moraes propõe a "categorização" que, em suma, é o procedimento de agrupar os dados, classificando-os por sua semelhança, de modo que seja possível uma compreensão mais aprofundada dos documentos que fazem parte do corpus de análise. De acordo com o autor, as categorias podem ser construídas a priori ou a partir do próprio material e podem ter aspectos mais gerais, que caminham para uma característica mais particular. As categorias criadas pelo pesquisador "necessitam ser válidas, pertinentes ou adequadas" (Ibidem, p.7) e para que correspondam à essas características devem ter fundamentação teórica e serem condizentes com os objetivos e respostas que se pretende responder por meio da pesquisa. Para além desses descritores das categorias, o autor ainda diz que estas precisam ter como critério a exaustividade, homogeneidade, exclusividade e objetividade. Exaustivas no sentido de possibilitarem que todo o conteúdo selecionado seja enquadrado na categoria criada; homogêneas porque precisam ter único critério de classificação; exclusivas porque um dado só pode ser incluído em uma categoria e objetivas porque não podem deixar dúvidas dos conteúdos de devem ser integrados à uma dada categoria.

As duas últimas etapas propostas pelo autor são a "descrição" e a "interpretação". A primeira delas é definida como o momento de expressar/descrever todos os significados da análise, expressando os significados presentes nos materiais e as intenções dos dados. É nesse momento de descrição dos materiais que os resultados aparecem, dando validade ao processo da pesquisa. Em última fase, temse a compreensão mais profunda do conteúdo analisado, ou seja, faz-se a interpretação dos conteúdos, sejam eles conscientes ou inconscientes, dando concretude aos resultados obtidos. 
Considerando os passos expostos por Moraes (1999), os tópicos a seguir apresentarão a revisão bibliográfica em que sua análise é realizada por meio deste referencial metodológico.

\subsubsection{Definição do corpus de análise}

De acordo com os objetivos da pesquisa, selecionou-se os principais eventos da área de ensino de Ciências, Astronomia e Física para compor a análise, sendo eles o Encontro Nacional de Pesquisa em Ensino de Ciências (ENPEC), o Simpósio Nacional de Ensino de Física (SNEF), Simpósio Nacional de Educação em Astronomia (SNEA), Encontro de Pesquisa em Ensino de Física (EPEF) e Simpósio Internacional de Educação em Astronomia e Astrobiologia (ISE2A), junto de revistas e periódicos internacionais que são: Revista Latino-Americana de Educação em Astronomia (RELEA) e Journal of Archeoastronomy and Astronomy in Culture. Estes últimos foram escolhidos por serem fontes importantes na área.

Em se tratando dos eventos, aqueles que ocorreram em datas mais antigas, ou que não têm eixos temáticos que abordem questões culturais, a busca foi realizada por palavras-chave (cultura, diversidade, indígena e astronomia) ou por essas palavras nos títulos dos trabalhos. Para os eventos que foram realizados mais recentemente, a busca foi realizada dentro das linhas temáticas dos eventos que abordam "Cultura", "Multiculturalismo" ou "Diversidade" em seu título. Com isso, todos os artigos que possuem questões que envolvem a astronomia, cultura e elementos culturais indígenas, foram selecionados para uma análise mais profunda.

Para a revisão bibliográfica referente ao ENPEC, primeiro filtrou-se dentro da linha temática do evento "Diversidade, multiculturalismo e educação em Ciências" os trabalhos relacionados exclusivamente ao ensino de Física, uma vez que este evento contempla trabalhos das áreas das ciências como um todo (Química, Física e Biologia).

Posterior a isso, relacionou-se aqueles trabalhos que apresentavam nas palavras-chave, palavras referentes ao multiculturalismo, diversidade ou conhecimentos indígenas e, em seguida, buscou-se relacionar os artigos que continham ambas as classificações - física e multiculturalismo, física e diversidade ou física e educação indígena - e ainda que tratavam de astronomia. Ou seja, para o 
trabalho ser selecionado, precisaria estar necessariamente na área de física e astronomia e tratar de temas multiculturais.

A tabela em que constam os resultados dos trabalhos encontrados no ENPEC encontra-se abaixo.

Tabela 1: Resultados dos trabalhos encontrados no ENPEC dentro da linha temática "Diversidade, multiculturalismo e educação em ciências".

\begin{tabular}{|c|c|c|c|c|c|}
\hline \multicolumn{6}{|c|}{ ENPEC } \\
\hline Anos & Áreas & $\begin{array}{l}\text { Total de } \\
\text { trabalhos }\end{array}$ & Multiculturalismo & $\begin{array}{l}\text { Conhecimentos } \\
\text { Indígenas }\end{array}$ & Astronomia \\
\hline \multirow{4}{*}{2017} & Biologia & 16 & 3 & - & - \\
\hline & Física & 3 & - & 1 & 1 \\
\hline & Química & 9 & 1 & - & - \\
\hline & Ciências & 41 & 4 & 1 & - \\
\hline \multirow{4}{*}{2015} & Biologia & 10 & - & 1 & - \\
\hline & Física & 6 & 1 & - & 1 \\
\hline & Química & 7 & - & - & - \\
\hline & Ciências & 32 & 2 & 4 & - \\
\hline \multirow{4}{*}{2013} & Biologia & 7 & 2 & 1 & - \\
\hline & Física & 4 & - & - & - \\
\hline & Química & 4 & - & - & - \\
\hline & Ciências & 20 & 3 & 3 & - \\
\hline \multirow{4}{*}{2011} & Biologia & 9 & 2 & - & - \\
\hline & Física & 6 & - & - & - \\
\hline & Química & 7 & - & 1 & - \\
\hline & Ciências & 12 & 1 & - & - \\
\hline \multirow{4}{*}{$\underset{* \star}{2009}$} & Biologia & 4 & - & - & - \\
\hline & Física & 2 & - & - & - \\
\hline & Química & 2 & - & - & - \\
\hline & Ciências & 12 & 1 & - & - \\
\hline
\end{tabular}

Fonte: Oliveira, 2020

*O ano de 2019 deste evento não pôde ser analisado, pois os trabalhos completos ainda não se encontram disponíveis em site. (Acesso em dez/2019) 
** Não possui divisão de categorias neste ano para este evento. Para isso, a pesquisa foi realizada pelas palavras-chave: cultura, indígena e diversidade.

Podemos perceber que o número de trabalhos relacionados a área de Física no ENPEC não apresenta grande destaque dentro do evento. Em todo caso, quando fazemos a intersecção das categorias do interesse da pesquisa, dois trabalhos possuem congruência com o tema de astronomia, cultura e conhecimento indígena, o que nos mostra quão escasso é a pesquisa neste ramo para esse tipo de evento.

Para os eventos SNEF, EPEF e SNEA, por serem mais específicos da área de Física e Astronomia, respectivamente, não houve uma classificação igual à do ENPEC. Nestes casos, usaram-se as temáticas dos próprios eventos em que se conste a diversidade e a cultura como temas centrais, acrescentado da busca por palavras-chave e palavras nos títulos dos trabalhos.

Tabela 2: Resultados dos trabalhos encontrados no SNEF dentro das categorias que abordam a cultura e a diversidade como eixo principal.

\section{SNEF}

\begin{tabular}{ccccc}
\hline Anos & $\begin{array}{c}\text { Total de } \\
\text { trabalhos }\end{array}$ & Multiculturalismo & Educação Indígena & Astronomia \\
\hline $\mathbf{2 0 1 9}$ & 66 & 1 & 1 & 6 \\
\hline $\mathbf{2 0 1 7}$ & 30 & - & - & 2 \\
\hline $\mathbf{2 0 1 5}$ & 13 & - & - & 2 \\
\hline $\mathbf{2 0 1 3}$ & 14 & - & - & - \\
\hline $\mathbf{2 0 1 1 ^ { * }}$ & 112 & - & - & 7 \\
\hline $\mathbf{2 0 0 9}$ & 12 & - & - & - \\
\hline
\end{tabular}

Fonte: Oliveira, 2020

*Neste ano, o evento não apresentou nenhuma linha temática relacionadas a cultura e a diversidade. Por esse fator, analisou-se a busca foi realizada pelas palavras nos títulos do evento como um todo.

Fazendo a análise do total dos 247 trabalhos neste evento, muitos foram encontrados contendo palavras "Astronomia" e "Cultura", porém todos eles têm como eixo principal a literatura ou o cinema, não tratando de elementos indígenas ou temáticas do interesse da pesquisa. Com isso, por mais que tenhamos encontrado 
um total de 17 trabalhos neste evento, somente 2 deles faz a ponte entre astronomia e conhecimento indígena e multiculturalismo.

No caso do EPEF, o evento não possui em nenhuma de suas edições uma linha temática que contenha temas multiculturais e, por essa razão, a busca foi realizada por meio das palavras nos títulos dos trabalhos do evento como um todo.

Tabela 3: Resultados dos trabalhos encontrados no EPEF

\begin{tabular}{ccccc}
\hline Anos & $\begin{array}{c}\text { Total de } \\
\text { trabalhos }\end{array}$ & $\begin{array}{c}\text { Multiculturalismo/ } \\
\text { Cultura }\end{array}$ & $\begin{array}{c}\text { Educação } \\
\text { Indígena }\end{array}$ & Astronomia \\
\hline $\mathbf{2 0 1 8}$ & 173 & 2 & 1 & 4 \\
\hline $\mathbf{2 0 1 6}$ & 156 & - & 1 & 12 \\
$\mathbf{2 0 1 4}$ & 175 & 6 & - & 4 \\
$\mathbf{2 0 1 2}$ & 199 & 5 & - & 4 \\
$\mathbf{2 0 1 0}$ & 149 & 5 & - & 3 \\
\hline
\end{tabular}

Fonte: Oliveira, 2020

Podemos perceber que este evento conta um número expressivo de trabalhos publicados, inclusive com um aumento de trabalhos que seguem a temática da astronomia. Na edição de 2018, por exemplo, aparece uma linha temática denominada "Equidade, Inclusão, diversidade e estudos culturais e o Ensino de Física", o que nos dá a entender que o número de trabalhos no evento com essa temática é significativo. De qualquer maneira, para esta revisão, somente dois trabalhos apresentaram congruência entre as temáticas e ambos foram encontrados na edição de 2018.

Para o SNEA, a tabela de classificações foi semelhante à do SNEF, porém, como este evento trata exclusivamente dos temas relacionados a astronomia, excluiu-se essa categoria da tabela. Pela tabela abaixo, podemos perceber a quantidade de trabalhos publicados que relacionam astronomia e multiculturalismo e astronomia e conhecimentos indígenas. Vale destacar que, muitos dos trabalhos que entraram na categoria de "conhecimentos indígenas" neste evento, também estão contabilizados na categoria multicultural, pois em sua maioria, encontra-se ambas as palavras no título ou nas palavras-chave. 
Tabela 4: Resultados dos trabalhos encontrados no SNEA.

\begin{tabular}{cccc}
\hline Anos & $\begin{array}{c}\text { Total de } \\
\text { trabalhos }\end{array}$ & $\begin{array}{c}\text { Multiculturalismo } \\
\text { Educação } \\
\text { Indígena }\end{array}$ & 3 \\
\hline $\mathbf{2 0 1 8}$ & 110 & 5 & 3 \\
\hline $\mathbf{2 0 1 6}$ & 95 & 5 & 2 \\
$\mathbf{2 0 1 4}$ & 132 & 3 & 1 \\
\hline $\mathbf{2 0 1 2}$ & 86 & 1 & 3 \\
\hline
\end{tabular}

Fonte: Oliveira, 2020

Este evento de foco em ensino de Astronomia foi o evento em que mais encontramos trabalhos que vão no sentido desta pesquisa, totalizando somente neste evento 19 trabalhos selecionados.

Para o evento internacional analisado (ISE2A), organizado pela IAU, consultouse todos os trabalhos que estavam disponíveis na íntegra - não considerando os que estavam somente com o resumo - nas atas do evento, totalizando 35 artigos. Como o evento não possui linhas temáticas, fizemos a busca pelas seguintes palavras-chave: culture, intercultural, indigenous. Apesar de 3 trabalhos apresentarem as palavras, somente 1 foi selecionado, pois os outros tratavam de astrobiologia e de povos da cultura norte-americana.

Em se tratando da consulta aos periódicos, todas as edições dos dois foram analisadas, totalizando 28 edições da RELEA e uma edição do periódico norteamericano, dando-nos uma análise total de 120 trabalhos.

Desta forma, dentre este limite de fontes consultadas, identificou-se 31 trabalhos que fizeram referência aos temas que articulavam astronomia, cultura e conhecimentos indígenas. 


\subsubsection{Resultados e algumas considerações}

A tabela a seguir apresenta os 31 trabalhos encontrados na revisão descrita na etapa anterior, com os títulos, autores, fontes e anos correspondentes.

Tabela 5: Trabalhos obtidos por meio da revisão bibliográfica com suas respectivas informações.

\begin{tabular}{|c|c|c|c|}
\hline \multicolumn{4}{|c|}{ Trabalhos } \\
\hline Título & Autores & Fonte & Ano \\
\hline $\begin{array}{l}\text { O universo das sociedades numa } \\
\text { perspectiva relativa: exercícios da } \\
\text { etnoastronomia }\end{array}$ & $\begin{array}{c}\text { Érika Akel Fares, Karla Pessoa } \\
\text { Martins, Lidiane Maciel Araujo e } \\
\text { Michel Sauma Filho }\end{array}$ & RELEA & 2004 \\
\hline $\begin{array}{l}\text { Astronomia e Cultura nas } \\
\text { pesquisas em Ensino de Ciências } \\
\text { na última década }\end{array}$ & $\begin{array}{c}\text { Vanessa Albuquerque, Clístines } \\
\text { Merlucci, Marta Rodrigues, } \\
\text { Cristina Leite }\end{array}$ & SNEA & 2011 \\
\hline $\begin{array}{l}\text { Astronomia Cultural nas fontes } \\
\text { etno-históricas: a astronomia } \\
\text { Bororo }\end{array}$ & Flavia Pedroza Lima & SNEA & 2011 \\
\hline $\begin{array}{c}\text { Astronomia e Educação } \\
\text { Intercultural: Experiências no } \\
\text { Ensino de Astornomia e Ciências } \\
\text { em escolas indígenas }\end{array}$ & $\begin{array}{l}\text { Flávia Cristina de Mello, Jules } \\
\text { Batista Soares, Leandro Kerber }\end{array}$ & SNEA & 2011 \\
\hline $\begin{array}{l}\text { Curt Nimuendaju, o conhecimento } \\
\text { do céu Ticuna/Maguta e a } \\
\text { observação do céu. }\end{array}$ & Priscilla Faulhaber Barbosa & SNEA & 2011 \\
\hline $\begin{array}{l}\text { Astronomia Cultural e Educação } \\
\text { Intercultural }\end{array}$ & Luiz Carlos Jafelice & SNEA & 2011 \\
\hline $\begin{array}{l}\text { Etnoastronomia: Um resgate das } \\
\text { culturas africana e indígena }\end{array}$ & $\begin{array}{c}\text { Andrea Zanatti; José Flávio } \\
\text { Siqueira }\end{array}$ & SNEA & 2012 \\
\hline
\end{tabular}


"Astronomia Cultural" em Livros Didáticos de Física aprovados no PNLEM 2012
Marta de Souza Rodrigues; Cristina Leite
SNEA

2012

Vicente Pereira de Barros e

Daneil Fernando Bovolenta

RELEA

2014

ducação em astronomia e seus

Ovigli

Potencialidades do Ensino de

Astronmia para uma formação

pautada na diversidade cultural:

Os céus dos povos indígenas no

Marta de Souza Rodrigues;

Cristina Leite

SNEA

2014

Brasil

O tema astronomia cultural nos referenciais curriculares estaduais no Brasil
Marta de Souza Rodrigues; Cristina Leite

ENPEC

2015

Astronomia nos Ensinos

Fundamental e Médio
Luiz Carlos Jafelice

RELEA

2015
"As coisas do céu":

Etnoastronomia de uma

comunidade indígena como

subsídio para a proposta de um

material paradidático
Caroline da Silva Garcia;

Samuel Costa.; Suzy Pascoali;

Mateus Zanette Campos
RELEA

2016

Journal of

Walmir Tomazi Cardoso

used by Indigenous Communities

in the Northwestern Amazonian Region

Culture

Jonathan Pires Janjacomo;

Geide Rosa Coelho

EPEF

2016 itinerante de Astronomia Indígena
Marta de Souza Rodrigues; Cristina Leite
SNEA

2016 materiais didáticos em Ensino de Astronomia Cultural 


\section{Ensino Intercultural em Astronomia com crianças indígenas*}

Maria José Ribeiro de Sá ,

Cleydson Wallace Castro da Silva, Antonio Gomes Guajajara, Daniela de Sousa

Cortez, Rivelino Cunha Vilela,

SNEA 2016 Silvia Lilian Lima Chagas , Uelber de Carvalho Farias

Astronomia Cultural em uma sequência didática: Uma discussão sobre os modelos

\section{Educação em Astronomia por meio da Geografia e da Cultura*}

Érika Kênia Sales Pereira

SNEA

2016
O céu fala e os povos ouvem:

Relato de uma ação pedagógica no Ensino de Astronomia Cultural ${ }^{*}$
Ellen Regina Romero Barbosa,

Paula Santos Orofino, Hamilton Perez Soares Corrêa
SNEA

2016
Conhecimentos Astronômicos Indígenas no Ensino de Ciências: inserção da Lei 11.645/08 no ensino fundamental
Laurita Istéfani da Silva Teles;

Suzane de Almeida Tomaczeski;

Caroline Dorada Pereira Portela
2017
ENPEC

2017

\section{-} Astronomy across cultures:
resporting experiences on the GalileoMobile education activities in the Paiter Suruí Indiigenous community

\section{Patricia Figueiró Spinelli; Ana \\ Paula Germano, Cristina}

Fernades; Sandra Benitez-

Herrera; Felipe Carrelli Sá Silva

ISE2A

2017 e Grupo GalileoMobile
Atividade com Gnômon Astronômico em uma comunidade indígena: Uma reinterpretação do conhecimento científico pela cultura Guarani-Mbyá
Guilherme Bruxel, Alexsandro Pereira e Daniela Borges Pavani
EPEF 2018 
Multiculturalismo na Educação

Básica: Uma análise da

Astronomia Cultural nos Livros

Érica de Oliveira; Cristina Leite $\quad$ EPEF 2018

didáticos de Física aprovados no

PNLD 2018

Astronomia Indígena: Aspectos iniciais no Ensino de Ciência

através da Interculturalidade e Interdisciplinaridade

Clístines Mariano Danieli

Merlucci; Gustavo Isaac Killner;

SNEA

2018

José Tomaz de Oliveira Junior

Vitor Feck Coelho, Guilherme

Bruxel, Daniela Borges Pavani,

Alan Alves Pinto

SNEA

2018

equinócio de primavera no planetário da UFRGS**

Vertentes da Astronomia Cultural no Brasil e seus possíveis reflexos na cosmoeducação**
Érika Kênia Sales Pereira; Paulo Henrique Azevedo Sobreira
SNEA

2018
Observatório solar indígena: Modelo didático para o ensino de Astronomia**
Anderson Giovani Trogello, Janer Vilaça, Ana Maria Pereira, Iohanna Elizabeth Beckers
SNEA

2018
SNEA

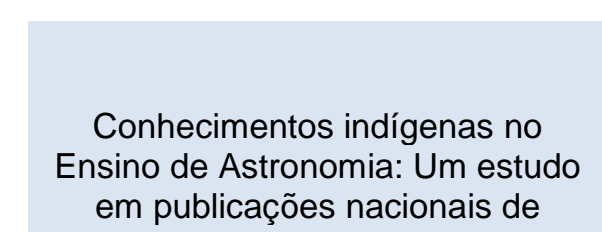
Educação em Astronomia
Letícia Fonsêca, Auta Stella de Medeiros Germano, Wellington Allyson de Araújo
SNEA

2018

\section{Reflexões sobre a Origem do
Universo nas Perspectivas} Ocidental e Indígena - Construindo novas narrativas através de uma proposta de Ensino Decolonial
Michelle Kênia Soares de Sena; Vivian Costa Ferreira; Beatriz Augusta Novais de Oliveira
SNEF 2019

\section{Astronomia Cultural nas pesquisas de ensino: um panorama da década atual (2010-2018)}

\section{Clístines Mariano Danieli} Merlucci; Gustavo Isaac Killner; José Tomaz de Oliveira Junior
SNEF 2019 
Todavia, faz-se necessário pontuar algumas questões acerca dos conteúdos da Tabela 05. Os trabalhos de Sá et al (2016), Pereira (2016) e Barbosa, Orofino, Corrêa (2016) foram selecionados na contagem geral dos trabalhos encontrados, por apresentarem nos títulos e nos resumos, temáticas e palavras-chave que são condizentes com a pesquisa, contudo, o trabalho completo não pôde ser encontrado nas atas do SNEA. Algo semelhante acontece com os trabalhos de Coelho et al (2018), Pereira e Sobreira (2018) e Trogello et al (2018) em que só é possível ter acesso aos resumos destes trabalhos na página do evento. Por essas razões, os seis trabalhos citados anteriormente não fizeram parte da análise, pela falta de elementos que esses resumos apresentam.

Sobre a quantidade de trabalhos correspondente a cada uma das fontes analisadas, temos:

Dos eventos:

- ENPEC - 2 trabalhos

- SNEF - 2 trabalhos

- EPEF - 3 trabalhos

- SNEA - 18 trabalhos

- ISE2A - 1 trabalho

Dos periódicos:

- RELEA - 4 trabalhos

- Journal of Astronomy in Culture - 1 trabalho

Após a leitura de cada um dos trabalhos selecionados, buscou-se extrair as informações necessárias para identificar os significados presentes no material para a criação das "unidades de significado" (MORAES, 1999) e, em seguida, estes foram agrupados em quatro grandes categorias, referente ao processo de categorização (MORAES,1999). Nesta etapa, de forma a articular este trabalho à outras pesquisas, mantivemos a natureza das categorias apresentadas no trabalho de Albuquerque et al (2011), uma vez que, parte do material analisado é o mesmo. Neste caso, as categorias são.: "Propostas de Ensino", "Documentos", "Fontes etno-históricas" e "Estado da Arte". A primeira categoria, por sua vez, foi subdividida em outras quatro, nas quais denominamos: "Formação de Professores", "Educação Formal", "Educação não-formal" e "Educação Indígena". 
O gráfico 1 representa uma síntese para a proposta de categorização realizada e o detalhamento de cada categoria será realizado a seguir.

Gráfico 1: Síntese das propostas de categorização da análise do levantamento bibliográfico.

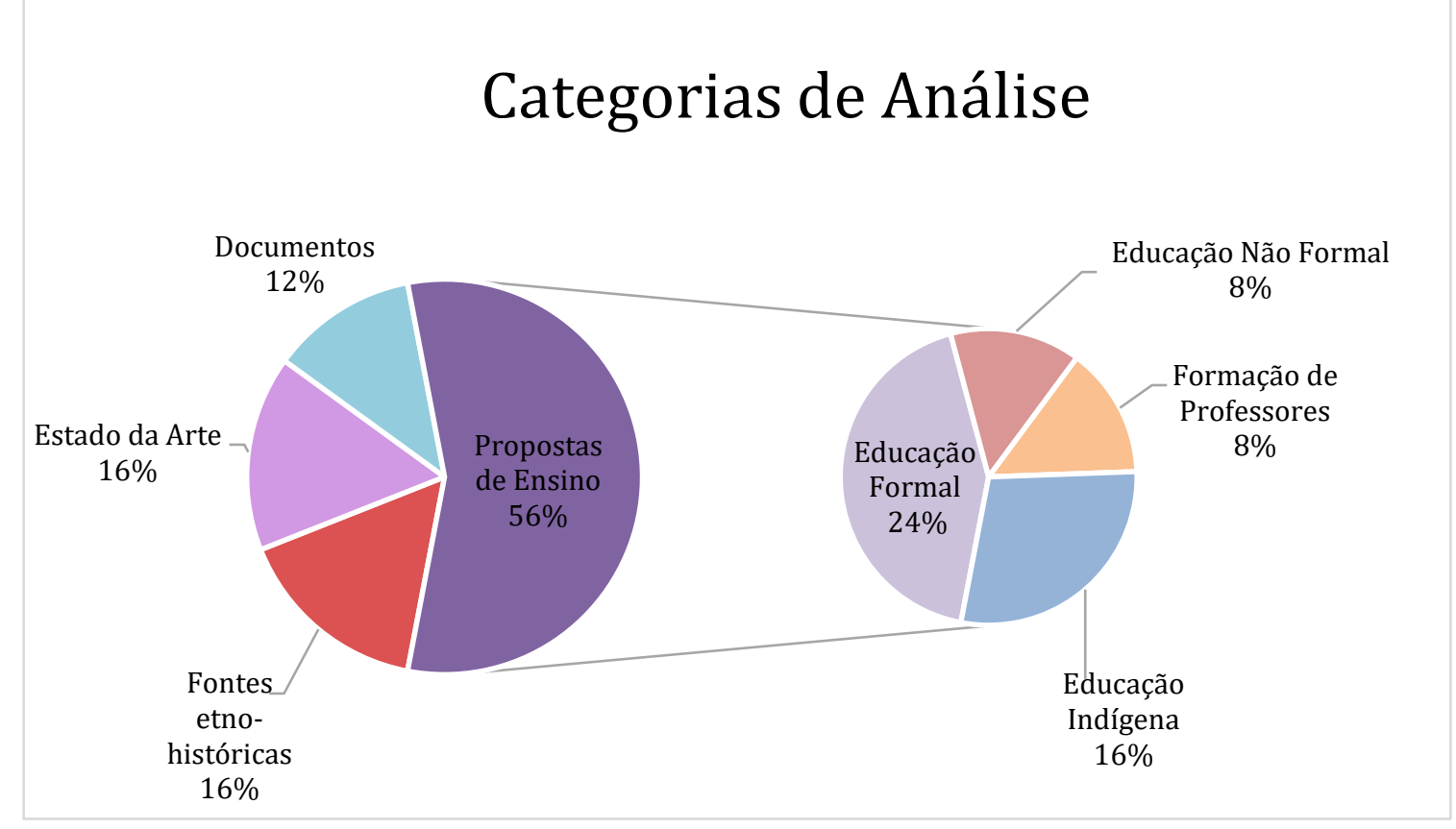

Fonte: Oliveira, 2020.

Do total de trabalhos analisados, 14 deles compõem a categoria que trata das propostas de ensino, referindo-se a intervenções relacionadas aos processos de ensino-aprendizagem que envolvem as temáticas da astronomia com concepções culturais para todos os níveis escolares.

Para a segunda categoria, 3 trabalhos foram encontrados. Esta aborda como a temática da astronomia cultural se apresenta em documentos como livros didáticos e propostas curriculares, em que se considera a importância da temática para a valorização da diversidade e as diversas formas de se relacionar com o céu.

A terceira categoria, denominada "Fontes etno-históricas" contém 4 trabalhos que trazem uma divulgação acerca dos saberes do céu produzidos por um determinado grupo por meio de pesquisa de campo. A última categoria agrupa os trabalhos que desenvolvem uma revisão bibliográfica da temática da astronomia cultural em diversas fontes como, revistas, periódicos, etc. 


\section{Categoria "Propostas de Ensino"}

Os trabalhos presentes nesta categoria, englobam propostas de todos os níveis de ensino e, a partir da análise das publicações e a identificação de assuntos em comum entre elas, criou-se as seguintes subcategorias: "Formação de professores"traz o conjunto de trabalhos voltados à professores com foco na astronomia cultural e saberes indígenas, independentemente da etapa de ensino; "Educação formal" e "Educação não formal" - agregam os trabalhos de propostas para esses dois ambientes e "Educação indígena" - contém propostas aplicadas em escolas indígenas por docentes não indígenas.

\section{a. "Formação de professores"}

Zanatti e Siqueira (2012) apresentam uma proposta de desenvolvimento de oficina pedagógica para professores de 6ª ano trazendo a apresentação de conceitos básicos de Astronomia e uma ênfase da Etnoastronomia com relação às culturas indígenas e africanas. Esta oficina consiste na utilização de atividades experimentais de baixo custo para os professores, além de uma apostila e, para os alunos, uma revista em quadrinhos confeccionada a partir dos conceitos de Astronomia e Etnoastronomia. Mesmo que seja apresentada uma justificativa acerca da importância desses conhecimentos, principalmente nos Parâmetros Curriculares Nacionais (PCN) não são encontradas questões referentes aos elementos que constituem a proposta, as questões de poder que envolvem a inserção do tema nos currículos, de maneira a dar voz a esses grupos que não são valorizados socialmente por seus saberes.

O trabalho realizado por Barros e Ovigli (2014) é desenvolvido por meio de uma sequência didática em curso de formação continuada voltado para professores da rede pública na forma presencial e à distância. Neste trabalho, os autores trazem à tona algumas questões acerca da ausência de temas culturais nos currículos, indicando a Lei 11.645/08 como uma das possibilidades de se incluir essas temáticas nas escolas brasileiras. Além disso, há um tópico em que se discute sobre a construção de currículos alternativos que leve em consideração os valores culturais principalmente locais - nos processos pedagógicos e como a História da Ciência pode auxiliar nessa questão. Neste ponto do texto, apresenta-se parte dos conhecimentos 
das culturas tupi-guarani e iorubás. De acordo com os autores, a intervenção foi realizada em dois momentos: 1. Apresentou-se as cosmogonias egípcias, gregas, iorubas e tupis, cada qual com uma metodologia diferente - livros didáticos, teatro ou multimídia. 2. Apresentação da importância da História da Ciência como trabalho coletivo e humano. Na reflexão final do texto, os autores consideram que por mais que se proponha quebrar algumas barreiras hegemônicas por meio de sequências didáticas à professores, de forma que valorizem a diversidade cultural, ainda é difícil superar o tradicionalismo escolar por conta da formação tradicional dos professores.

\section{b. "Educação formal"}

Rodrigues e Leite (2014) propõem neste trabalho, alternativas concretas para se levar a Astronomia Cultural para a sala de aula por meio de duas temáticas e um "tema transversal", de forma a colaborar com o reconhecimento da diversidade cultural brasileira - em específico, de algumas populações indígenas do Brasil - e a importância da inserção da Lei 11.645/08. No presente texto, as autoras abordam em um dos tópicos, a relação do multiculturalismo com a educação deixando claro a importância da criticidade do tema e das questões monoculturais e de poder que permeiam essa relação no processo educativo. O tema transversal sugerido trata-se da história e cultura das populações indígenas no Brasil, em que as autoras sugerem algumas obras que podem auxiliar/guiar os professores de maneira a se ter mais concretude ao discutir as culturas dos povos indígenas, os saberes e os papéis desses povos ao longo da história do nosso país. Em relação às duas temáticas em que sugerem as autoras, tempo "Mapeamento do céu, estrelas e constelações" e "Narrativas míticas", ambas são apresentadas de maneira embasada, com a sugestão de diversos autores da área para que haja uma aproximação dos temas para a possibilidade da inserção da astronomia cultural na escola.

Jafelice (2015) desenvolve um trabalho destinado à professores das mais diversas áreas, mas que tenham como objetivo comum, discutir a importância da perspectiva antropológica em conjunto com os assuntos que envolvem a astronomia. Para isso, o texto do autor apresenta propostas didáticas que podem auxiliar os professores a levar os assuntos da Astronomia Cultural - tanto para o ensino formal ou não formal - para qualquer etapa da educação básica. Neste trabalho de Jafelice, é possível perceber uma discussão bastante ampla - e rica - que conceitua a 
importância da área, os aspectos ideológicos que baseiam a temática, a potência da implementação da Lei 11.645/08 no currículo e quais seriam os sentidos das propostas que por ele são apresentadas. Ao longo do texto, o autor traz imagens de experiências já vividas por ele e outros educadores, sugestões de tarefas com a descrição detalhada de cada uma delas e como prosseguir adiante, inclusive chamando a atenção dos educadores que se interessam pela proposta, de que as atividades também devem ser realizadas pelos docentes, uma vez que em uma proposta holística não existe um único resultado, e até explicações mais "conceituais" de conhecimentos astronômicos. Como consideração, Jafelice evidencia a possibilidade de adaptação das atividades propostas neste trabalho, mas que o sentido e significado da proposta seja mantida.

Teles et al (2017) apresenta uma proposta de ensino realizada por um grupo de PIBID (Programa Institucional de Bolsas de Iniciação à Docência) ministrada no 3º ano do Ensino Fundamental, cujo objetivo é a inserção da Lei 11.645/08 - lei que determina o estudo da história e cultura afro-brasileira e indígena na educação básica - por meio de uma proposta que envolvem as constelações indígenas. A proposta trata de temas da Astronomia (brilho das estrelas e suas temperaturas, estrelas errantes e a refração) mas é focada em temas da cosmologia indígena como, por exemplo, as constelações e suas histórias, suas orientações e suas relações com determinadas épocas do ano. Apesar da proposta apresentar diversos conteúdos dos conhecimentos indígenas, não existe (ou pelo menos não é claro) uma discussão crítica sobre a importância desta temática. Ou seja, por mais que a atividade proposta seja aplicada com atividades que envolvem um viés artístico, podendo ser aplicada em diversas turmas, não foi possível perceber que houve uma conscientização das razões que envolvem a importância deste tema ser trabalhado com as crianças.

Sena et al (2019) nos trazem uma proposta didática aplicada no ensino médio de uma escola pública de São Paulo. Segundo as autoras, essa proposta tem a intenção de promover um espírito crítico com os alunos de forma a se repensar os modos em que se perpetuam as concepções de ciência na sociedade com a finalidade de refletir sobre o conhecimento científico hegemônico e valorizar outras formas de conhecimento. Para isso, fez-se uma proposta usando duas aulas: 1. Realizou-se uma atividade com frases que trazem aspectos da origem do Universo baseadas na cosmologia ocidental e na cosmologia indígena de etnia Guarani Mbyá. 2. Mostra de vídeos que questiona os impactos causados pela utilização irresponsável e 
desgovernada de recursos naturais fomentados pelos avanços tecnológicos da ciência tradicional e escrita de texto sobre a veracidade de um determinado conhecimento. Como resultado, as autoras apontam que em um primeiro momento, os alunos assumiram uma postura de inferiorizar o conhecimento advindo da cultura indígena, mas que, ao longo das atividades, puderam mudar de postura, demonstrando respeito à essa cultura.

Lacerda (2016) apresenta uma sequência didática baseada nas Orientações Educacionais Complementares aos Parâmetros Curriculares Nacionais do Ensino Médio $(\mathrm{PCN}+)$ de Física no tema estruturador "Universo, Terra e Vida". O objetivo da proposta, de acordo com o autor, é de que, os alunos possam dialogar sobre origem e evolução do universo sob as diferentes perspectivas culturais. Apesar o autor trazer a questão da importância da Astronomia cultural, essa questão não fica clara na descrição da proposta. Em linhas gerais, a proposta apresentada neste trabalho consiste em apresentar o fenômeno da origem do universo, de um lado, sob o viés mítico e teológico e do outro, o filosófico e científico. As possíveis conexões sociais, etnocêntricas e valorização epistêmica não se fazem presentes. Vale ressaltar que essa proposta não foi aplicada, mas serve de inspiração para outros professores, como aponta o autor.

Em Junior, Killner, Merlucci (2018) encontramos um relato de experiência em aulas de Física para o primeiro ano do Ensino Médio de uma escola regular em que foram inseridos temas da Astronomia Indígena Brasileira. Este trabalho foi desenvolvido em conjunto com as disciplinas de História e Geografia e teve por objetivo levar aos alunos a oportunidade da construção do conhecimento de forma a valorizar a diversidade, em especial os povos indígenas, além de trazer uma reflexão para o papel docente. A proposta descrita pelos autores consistiu em 3 etapas, sendo elas o processo histórico e antropológico dos povos de etnia Tupi e Guarani, os processos ligados aos territórios desses povos e o procedimento científico ligado ao estudo do céu pelos indígenas. Para as atividades da proposta, usou-se uma carta celeste e a o estudo sobre as constelações, buscando fazer uma análise das semelhanças e diferenças entre os saberes tradicionais e destas etnias. As considerações de Junior, Killner e Merlucci (2018) são de apresentar alternativas para se trabalhar no ensino formal de maneira intercultural, de forma que essa perspectiva possa balizar a prática docente. 


\section{c. “Educação Não-formal”}

No trabalho de Janjacomo e Coelho (2016), os autores buscam analisar os saberes que movem uma atividade pedagógica de característica não formal, sendo este o caso referente à Sala Itinerante de Astronomia Indígena (SIAI) que corresponde a um subprojeto de Física do programa PIBID/UFES. A Lei 11.645/08 é citada no texto como uma das razões do surgimento desta sala temática. Todavia, apesar deste trabalho desenvolver atividades em uma sala de astronomia indígena, o foco maior acaba sendo no que diz respeito a educação não -formal, não deixando claro o que de fato é exposto nesta sala, quais atividades este grupo propõe, que elementos são trabalhados nas propostas deste ambiente para que haja o reconhecimento e 0 respeito à pluralidade cultural no ensino de ciências.

Em Fares et al. (2004) os autores apresentam uma atividade desenvolvida em oficina no Planetário do Pará, em que a temática central são as Constelações. Esse trabalho do planetário tem o intuito de promover a expansão da Etnoastronomia e promover a tolerância perante a diversidade cultural. Ao longo do trabalho é apresentado algumas classificações de constelações desenvolvidas ao longo dos tempos, classificando-as em "Constelações Clássicas" e "Constelações Modernas", mas não é possível identificar no texto como esse conteúdo é desenvolvido ao longo da oficina proposta no planetário, nem como é abordado e se está inserido em alguma atividade específica, etc. Os autores expõem brevemente sobre as constelações dos povos Tembé, mas não especifica como esse tema é tratado na atividade desenvolvida. As discussões e reflexões dos autores se dão na necessidade de se pensar o mundo em uma perspectiva mais plural, mas ao longo o trabalho não é exposto de maneira evidente os motivos pelo qual se deve a importância dessa pluralidade que é almejada.

\section{d. "Educação Indígena"}

No texto de Garcia et al (2016), os autores trazem uma proposta realizada em uma escola indígena por meio de uma oficina pedagógica sobre o conhecimento cosmológico da cultura indígena para a produção de material paradidático. Para a confecção deste material, os autores fizeram uma coleta de dados por meio de uma entrevista com os conhecedores tradicionais da tribo (JAFELICE, 2012 apud Garcia 
et al 2016), de forma a se obter explicações dos conceitos de elementos do céu como, criação do Sol e da Lua, surgimento das estrelas, estações do ano, etc, além de contar com as histórias trazidas pelos caciques e professor indígena da comunidade. Este trabalho ainda faz uma ampla explicação sobre os estudos etnoastronômicos, trazendo à tona a necessidade de valorização dos saberes indígenas nas escolas propriamente indígenas e as que não são.

A proposta de Mello, Soares e Kerber (2011) trata do ensino de astronomia e ciências em escolas indígenas, em especial, na formação de professores indígenas para o trabalho dentro de comunidades indígenas locais do sul da Bahia. No texto, os autores defendem a ideia da astronomia cultural sendo pensada como parte integrante das outras disciplinas, acarretando em uma formação de professores para a diversidade. Os dados do trabalho se baseiam em dois cursos de extensão, sendo eles: 1. Céu na Praça- onde ocorrem observações astronômicas em comunidades tradicionais e indígena. Este evento é público e tem como proposta, levar o conhecimento da ligação do ser humano com a natureza. 2. Curso de formação de professores indígenas- reúne professores e alunos indígenas e não-indígenas para a interlocução com as comunidades indígenas locais nas áreas de ciências, tendo como eixo central a interculturalidade e interdisciplinaridade. As etnias pesquisadas são os Tupinambá e Pataxó Hahahãe. No final do texto, temos um exemplo de estudo de caso sobre astronomia cultural indígena como forma de discutir a interculturalidade no ensino de ciências.

O trabalho de Spinelli et al (2017) trata de um relato de expedição de ensino de astronomia nas comunidades indígenas de etnia Paiter Suruí, realizada pela iniciativa GalileoMobile - iniciativa sem fins lucrativos e itinerante que promove educação científica de forma a levar a astronomia em regiões com pouco ou nenhum acesso à ações de divulgação da ciência. O objetivo dessa expedição é de trocar conhecimentos relacionados à Astronomia, promovendo o diálogo em esse grupo étnico de maneira a se registrar e entender suas relações com o cosmos. Para isso, realizou-se entrevistas com os mais velhos, que foram gravadas, registradas e que futuramente serão devolvidos aos Paiter Suruí como forma de recurso para estudos etnográficos e como forma de se preservar esses conhecimentos. Neste processo coletou-se três mitos relacionados aos astros Sol e Lua e o fenômeno do arco-íris. Neste trabalho, os autores descrevem o surgimento deste programa itinerante em 2008, quais são os objetivos que inspiram esse projeto e as características dos povos 
de etnia Paiter Suruí, junto das atividades desenvolvidas com eles. Estas últimas consistem em observação do céu (diurno e noturno); contação de histórias; cineclube; representação por meio de desenhos e explicações dos astrônomos de fenômenos científicos, etc. Como resultados, os autores trazem parte de um conto sobre a Lua narrado pelo grupo indígena, apontando que essa pesquisa serviu de base para uma monografia e dissertação que apresentam os resultados de maneira mais profunda.

Em Bruxel, Pereira e Pavani (2018), o trabalho é desenvolvido em escola fundamental indígena com uma atividade que tem por objetivo analisar o modo como a etnia Guarani Mbyá interpreta os conhecimentos científicos tradicionais ocidentais. Para isso, a atividade consistiu em obter os pontos cardeais por meio de um gnômon astronômico, e foi solicitada pelo cacique da própria aldeia, uma vez que já existia com esse grupo, uma rosa dos ventos indígena. Segundo os autores, ao ensinar um conhecimento advindo da cultura "branca", o grupo desenvolveu uma certa cautela para que não se transmita a ideia de que há uma superioridade epistemológica do céu. Com isso, é contextualizado nesse trabalho, a importância de se dar voz à várias identidades culturais, a valorização da astronomia cultural e do intercâmbio de saberes. No texto também é descrito de maneira breve quais são as principais características deste grupo indígena e não há uma descrição detalhada da atividade, ainda que as imagens possam dar uma ideia de como foi realizada. Como resultado, concluem que os conhecimentos ocidentais podem ser passados a esses grupos de maneira que também os seja relevante e podem ser interpretados também por outras culturas.

\section{Categoria "Documentos"}

Os trabalhos que compõem esta categoria, trazem a presença da astronomia cultural em documentos curriculares ou materiais didáticos, mostrando-nos um panorama da presença da temática nestes contextos.

A pesquisa de Rodrigues e Leite (2012) consiste em uma análise de Livros Didáticos de Física que foram aprovados no PNLEM - Programa Nacional do Livro Didático do Ensino Médio - referente ao ano de 2012, com o objetivo de compreender como a Astronomia Cultural é apresentada e qual a frequência com que essa temática aparece nas 10 coleções analisadas. O texto das autoras traz consigo uma justificativa 
da importância da análise dos livros, por ser um objeto cultural. Com relação à metodologia e os resultados obtidos, encontram -se três grandes categorias, sendo: Cultura na Astronomia - influências culturais que se relacionam à Astronomia -, Diversidade Cultural - agrupa as organizações e produções culturais para além das concepções ocidentais - e Outros, que contém os materiais que apresentaram poucas contribuições na temática da Astronomia Cultural. Neste trabalho, com exceção de duas coleções que têm grandes unidades nos livros que tratam de Astronomia, a maioria dos livros se encaixou nesta última categoria em que há pouca contribuição para estudos culturais na área. Como consideração, Rodrigues e Leite (2012) evidenciam a importância de discutir os apontamentos que colocam a ciência em um contexto mais amplo, que propicie aos alunos uma postura mais crítica diante os saberes para além do tradicionalmente científico.

Rodrigues e Leite (2015) apresentam uma análise dos referenciais curriculares estaduais brasileiros de ciências e física sobre a aparição de elementos que constituem a astronomia cultural. As autoras ressaltam os processos histórico-cultural do multiculturalismo no Brasil, além de trazerem as leis 11.645/08 e 10.639 como elementos importantes do resultado das lutas dos movimentos sociais. Com isso, o texto mostra uma análise dos conteúdos que são encontrados em cada um dos currículos estaduais, bem como, se a astronomia cultural presente nestes documentos são representativas. Com isso, tem-se um olhar ampliado daquilo que se consta nos documentos oficiais e, como considerado pelas autoras, como as propostas curriculares foram propostas após as leis citadas entrarem em vigor, trazendo a urgência de mudança nos planos que trazem a temática da astronomia cultural como tema importante para tratar das culturas destes povos.

Em Oliveira e Leite (2018), encontramos um trabalho em que é realizada uma análise dos livros didáticos de Física aprovados no PNLD - Programa Nacional do Livro Didático - referente ao ano de 2018. A análise tem como objetivo compreender a forma e a frequência de como a astronomia cultural vem sendo levada até as salas de aula por meio deste tipo de material e teve com aporte teórico o multiculturalismo crítico. As autoras apresentam quais são as interseções entre escola e cultura e a importância de se ter um ambiente que valoriza a diversidade e como se faz necessária uma postura crítica dos educadores para que as diferenças possam estar presentes no contexto escolar. Com relação à metodologia e análise, mostra-se a importância dos livros didáticos e seus múltiplos papéis, quais coleções de livros 
foram analisadas e a importância da Lei 11.645/08 para fundamentar a obrigatoriedade dos conteúdos afrodescendentes e indígenas no material analisado. Com isso, Oliveira e Leite construíram a partir da análise duas grandes categorias, em que a primeira, denominada de "Monocultural" aborda os conteúdos científicos clássicos e a segunda "Menos valorizados socialmente" que traz saberes de grupos culturais que sofrem uma desvalorização. Como resultado, ressaltam a falta de conteúdo desta segunda categoria e que, quando apresentada, o conhecimento oriundo destes grupos é tratado como primitivo, ultrapassado e "crendice".

\section{Categoria "Fontes etno-históricas"}

Esta categoria contém trabalhos que trazem à tona obras sobre os diferentes saberes sobre o céu e uma discussão sobre a Astronomia Cultural, utilizando-se de fontes primárias.

O trabalho de Lima (2011) que compõe esta categoria nos traz diversos dados do sistema cosmológico dos Bororo - situados na região de Goiás, Mato Grosso, Mato Grosso do Sul e leste da Bolívia - utilizando fontes etno-históricas de meados do século XX. Neste texto, a autora nos apresenta diversos dados sobre os astros e conhecidos celestes deste grupo indígena, como seus saberes acerca das posições do Sol, estações do ano, eclipses e a contagem do tempo. Alguns aspectos sobre a organização social deste povo e sua relação com o cosmos também são apresentados. Todos os dados apresentados no trabalho partem de uma pesquisa de campo, além de serem utilizados materiais de literatura como, por exemplo a Enciclopédia Bororo (ALBISETTI E VENTURELLI, 1962, 1969, 1976 apud LIMA, 2011).

O texto de Jafelice (2011) traz uma discussão acerca das dificuldades/problemas que envolvem formação em astronomia cultural. Para isso, o autor se baseia em três obras literárias de Astronomia, ressaltando os principais pontos críticos deste tipo de narrativa. Neste caso, os textos trazem uma narrativa etnocêntrica (somente pelo ponto de vista europeu), tratam a história de maneira linear e anacrônica, o termo "primitivo" com um significado pejorativo aplicado a qualquer grupo que não se encaixe na civilização européia, além de dar um sentido de que esse homem ainda não evoluiu, o conhecimento científico como sendo o único libertador, entre outros pontos. Por fim, o autor ressalta a gravidade das narrativas ao 
apresentarem concepções que envolvem a astronomia, pois essas descrições contribuem para a construção de barreiras com outros conhecimentos sobre os diferentes povos. Para Jafelice (2011), também é necessário que haja uma mudança na formação em ciências exatas, de tal forma que se tenha uma formação dos astrônomos na área de humanidades, como história, filosofia e, principalmente, a antropologia.

No trabalho de Cardoso (2016), o autor nos apresenta uma pesquisa realizada no noroeste do estado do Amazonas no período de 2005 a 2007 em comunidades indígenas Tukano, Desana e Tuyuka para a realização do mapeamento do céu com base em estudos da etnomatemática e em outros estudos de antropólogos e pesquisadores do século XX. Para isso, o autor, juntamente dessa comunidade realizara a construção de um calendário astronômico dinâmico e circular em que se integra condições ambientais e climáticas com base nas constelações desse povo. Em dois anos de pesquisa, o autor conta que foi possível desenvolver três oficinas, a primeira para captar dessa comunidade todo o conhecimento local acerca da leitura e relação com o céu e a segunda e terceira para construção do calendário. Além disso, o autor descreve as técnicas usadas para desenvolver a pesquisa em três partes: 1. Os pesquisadores compartilharam com estes povos indígenas, os "mitos" ocidentais que permearam a construção das nossas constelações- Órion e Escorpião, por exemplo - de forma que houvesse uma abertura para o compartilhamento também por parte desse povo. 2. Realizada por meio de contadores de histórias, a segunda oficina contou com a ajuda das pessoas mais velhas da comunidade a fim de reconhecer no céu as constelações que outros antropólogos antigos haviam mapeado em seus estudos. $O$ autor ressalta que as contações de histórias foram realizadas mais de uma vez em locais e noites diferentes, para sobre um mesmo astro no céu para confirmar as informações. Cardoso descreve em detalhes quais são os conhecimentos do céu pelos Tukano - constelações, relações de fenômenos com a vida cotidiana, Lua e Sol, plantio, questões meteorológicas, etc - que foram descritos no calendário circular construído e a importância da sistematização deste conhecimento em forma de calendário como forma de organização de pensamento desse próprio povo.

Barbosa (2011) propõe em seu texto uma interface entre a antropologia social e a história cultural da ciência, com base nos trabalhos coletados pelo etnólogo Curt Nimuendaju no que diz respeito ao seu trabalho de documentação da cosmovisão dos 
povos Ticuna. Segundo a autora, o etnólogo possuía conhecimentos de astronomia, sendo possível o registro e a identificação das constelações Ticuna. Com esses registros, a autora foi capaz de reproduzir por meio do software Starry Night o céu dos Ticuna e promover indagações e questões acerca dos conhecimentos desse povo e com os movimentos dos astros. Desta forma, a essência do trabalho proposto por Barbosa é a história da etnografia da percepção indígena sobre o céu e a relação com a organização social e condições ambientais, de forma a trazer uma correlação entre esta cosmovisão com as visões tradicionais do que concerne o estudo da astronomia, de forma a se considerar uma discussão entre as diferenças nas lógicas de pensamento das culturas. A autora apresenta brevemente em seu texto alguns exemplos dos conhecimentos dos Ticuna registrados por Curt Nimuendaju, como a construção do calendário agrícola, o movimento dos planetas e a constelação da Queixada do Jacaré (área do céu correspondente à constelação de Touro) e traz em evidência nos referenciais metodológicos do trabalho a importância de estarmos abertos para conhecer e buscar compreender outras formas de pensamento e outras lógicas culturais sem usar de comparativos com o pensamento ocidental tradicional . Com esse trabalho, Barbosa pretende contribuir para o banco de dados das peças Ticuna em Museus do Exterior e do Brasil.

\section{Categoria "Estado da Arte"}

Albuquerque et al (2011) desenvolve um trabalho trazendo um estado da arte de pesquisas que relacionam Astronomia, Cultura e Ensino em artigos publicados nos principais eventos de ensino de ciências e em revistas, periódicos nacionais, banco de teses e dissertações e outras fontes conhecidas pelos autores. É possível perceber neste trabalho uma preocupação com a supervalorização da ciência ocidental em detrimento da posição de poder desse conhecimento e a importância de compreender a ciência com uma construção humana, caracterizando-a como mais uma das visões de mundo possível. Sobre os trabalhos encontrados, os autores relatam que somente 11 trabalhos se alinham com os objetivos da pesquisa e estes foram categorizados conforme suas semelhanças, sendo elas: Reconhecimento Cultural e Proposta de Ensino. Na primeira, agrupou-se os trabalhos que tratam dos saberes astronômicos produzidos por diferentes culturas. Por meio desses resultados, criou-se duas subcategorias, apontando aqueles trabalhos que realizaram pesquisas de campo 
(subcategoria "pesquisas em campo") e outros que se baseiam em referências externas por meio de pesquisas etnográficas (subcategoria "pesquisas em fontes etnográficas"). Já a segunda categoria apontada pelos autores trata-se das propostas de ensino, separadas por aquelas que fazem parte do ensino formal - mais especificamente em holísticas e interdisciplinares - e não formal. Os autores ressalvam que as pesquisas na área ainda são escassas (no período analisado) e almejam que o trabalho possa servir de impulso para outras pesquisas tanto para documentação dos conhecimentos do céu, quanto para construir um material de apoio para professores.

Em Merlucci et al (2019), os autores apresentam uma pesquisa acerca de uma revisão bibliográfica inserida em dissertação de mestrado, sobre a presença da temática da Astronomia Cultural em periódicos da área de ensino de Física, Ciências e Astronomia, em banco de teses e dissertações e em revistas nacionais de Qualis A1, A2, B1 e B2. Segundo os autores, essa revisão é extensão de um trabalho já publicado nas atas do I SNEA (Albuquerque et al 2011) em que já foi dado um panorama das pesquisas da área e, com isso, faz parte do objetivo deste trabalho, traçar como as pesquisas em Astronomia Cultural vieram se desenvolvendo ao longo de 18 anos de área. Neste trabalho, além dos autores apresentarem os resultados do estado da arte, também trazem uma contextualização da importância de um currículo multiculturalista e da Lei 11.645/08 além das possibilidades e desafios da astronomia cultural a serem levadas à sala de aula. Como resultado, Merlucci et al (2019) encontram em uma análise de 4500 trabalhos, somente 17 que se aproximam dos interesses desta pesquisa. Como este trabalho é uma extensão do publicado em 2011, as categorias foram mantidas - Propostas de Ensino, Reconhecimento Cultural - e criou-se uma outra para complementar a pesquisa, denominada "Análise Documental". Apesar da porcentagem de trabalhos encontrada ser pequena, os autores apontam um crescimento no número de publicações que tratam da temática e destacam a criação da Lei 11.645/08 como uma possível justificativa para esse aumento.

Rodrigues e Leite (2016) apresentam um trabalho que propõe uma discussão de para a inserção da diversidade cultural, justificada pela Lei 11.645/08 no ensino de ciências exatas e, com isso, analisa uma série de materiais didáticos e propostas que possam abordar a astronomia cultural. Para essa pesquisa, as autoras destacam a importância dos movimentos sociais no contexto brasileiro - em especial dos povos 
indígenas - que acarretaram na legitimação de um espaço de grupos subalternos no currículo escolar. Traz-se também um embasamento teórico sobre as concepções de cultura que se espera quando tratamos da multiculturalidade. Para o corpus de análise, as autoras utilizaram da Proposta Curricular do Estado de São Paulo, livros didáticos, teses e dissertações e relatos de experiência. O que podemos encontrar de resultado segundo Rodrigues e Leite (2016) é que existe uma tendência dos materiais analisados em não mencionar a Lei 11.645/08 como parte da fundamentação pedagógica; quanto à astronomia cultural, a maioria dos materiais desenvolvidos antes da implementação da lei atingiam ou eram destinados à um público mais restrito (professores e/ou interessados no geral) e que após à lei houve uma maior concentração nos materiais didáticos. As autoras consideram que somente a presença da lei não garante que as mudanças atinjam o ambiente escolar de forma a se promover um lugar de cruzamento de culturas.

No trabalho desenvolvido por Fônseca, Germano e Araújo (2018) encontramos uma revisão bibliográfica que tem por objetivo reconhecer como as pesquisas na área de astronomia tem lidado com os conhecimentos indígenas. Para isso, os autores consideraram nesta revisão a Revista Latino Americana de Educação em Astronomia (RELEA) e o Simpósio Nacional de Educação em Astronomia (SNEA) até o ano de 2017. Percebemos ao longo do presente trabalho que a Lei 11.645/08 é considerada como propulsora para aumento de produções de pesquisas na área de Astronomia Cultural. É exposto no artigo os trabalhos encontrados e as categorias nos quais os mesmos foram distribuídos tiveram como inspiração o trabalho de Albuquerque et al (2011) - já citado nesta mesma categoria - mas com algumas complementações de subcategorias. Sobre os resultados obtidos, os autores são incisivos a evidenciar a deficiência de trabalhos voltados para a educação formal, o que seria uma maneira de se levar esses conhecimentos de outras culturas para a escola tradicional, bem como, essa mesma falta na formação de professores, concluindo, segundo os autores que o processo de valorização multicultural não está sendo contemplado no processo escolar. Sobre os conhecimentos que estão vinculados às propostas analisadas, os autores chamam a atenção para o caráter utilitarista dos saberes indígenas, podendo distorcer a essência que os povos indígenas têm com relação as "coisas do céu". 


\subsection{Algumas considerações}

Um dos pontos que vale destaque no que diz respeito à revisão descrita e analisada anteriormente, é a quantidade de trabalhos que compõe a análise.

Alguns dos eventos acima citados apresentam uma longa jornada e, com isso, é possível perceber que a temática da diversidade cultural - e outros temas sociais/ambientais/de gênero - vêm ganhando certo espaço e dedicação, chegando a tornar linhas temáticas em eventos de pesquisa, mesmo dentro de uma área que já foi tão tradicional - no caso das ciências exatas. Um possível motivo para que tenhamos identificado esse crescimento é que, o recorte do período analisado é posterior à vigência da Lei $11.645 / 08$, em que é determinada a inclusão dos conhecimentos indígenas e afro-brasileiros em todo o currículo escolar. Todavia, como a análise foi realizada nos trabalhos como um todo, conseguimos perceber se os conhecimentos obrigatórios pela lei estão sendo tratados de forma utilitarista e cumprimento de currículo, ou se há uma estratégia pedagógica e de pesquisa de forma significativa e crítica.

Buscamos nos trabalhos essa segunda visão em virtude de reconhecermos as lutas e atuação dos movimentos indígenas e afro-brasileiros em busca de visibilidade, voz e reconhecimento por suas culturas e matrizes. Por isso, uma lei dessa natureza acaba por ter papel mais do que significativo no âmbito da educação e, consequentemente, deve ser cumprida de forma crítica e viva. Fazendo um paralelo com as ideias propostas por Candau (2013): que tipo de multiculturalismo se faz presente nos trabalhos encontrados?

Com relação à essa questão, percebemos algumas problemáticas nos trabalhos como, por exemplo, o número de páginas dos artigos é em média de oito a dez, o que muitas vezes limita os autores de descrever com riqueza de detalhes as formas em que os estudos foram feitos. Todavia, as pretensões, o que se busca valorizar e os aportes teóricos muitas vezes nos deixa mais claro a natureza das publicações.

No caso dos trabalhos na categoria "Propostas de Ensino", alguns apresentam um caráter mais diferencialista (CANDAU, 2013) em que os conhecimentos da cultura indígena são expostos, se reconhece as diferenças para com o conhecimento tradicional científico, mas não refletem e reconhecem as tensões mais profundas entre ambos, trazendo uma discussão mais rasa de "diferenças e semelhanças" 
epistemológicas. Nessa perspectiva, podemos citar os trabalhos de Fares et al (2004) e Lacerda (2016).

Das publicações que podem se alinhar ao que Candau (2013) propõe como multiculturalismo intercultural, encontramos em Jafelice (2015) uma proposta de caráter holístico que discute de maneira profunda a importância do olhar antropológico nos estudos da astronomia. Assim, o autor chama a atenção para a valorização de um leque epistemológico, fazendo-se um possível intercâmbio de saberes, como é proposto nessa visão multicultural.

No caso da presença de propostas na subcategoria "Formação de Professores", ainda que possamos perceber na análise uma certa preocupação com a prática docente, o número de trabalhos que foram agrupados nessa linha é muito pequeno. Realizar atividades que visem auxiliar os professores a inserir em sua prática 0 reconhecimento da diversidade nos contextos culturais, construindo para uma formação menos monocultural, etnocêntrica e ocidental.

De maneira geral, o levantamento bibliográfico nos proporciona uma visão do cume da montanha, de forma a identificar quais são nossos horizontes e onde estamos inseridos. Fazendo um paralelo com o trabalho de Albuquerque et al (2011) em que as conclusões de quase uma década atrás eram de poucos trabalhos na área de ciências, podemos dizer que o aumento não foi muito significativo. Ainda que as fontes não tenham sido todas as mesmas, nossa pesquisa contou com os principais eventos da área e por isso almejávamos uma extensão de números de publicação. 


\title{
CAPÍTULO 3: ASTRONOMIA CULTURAL NOS LIVROS DIDÁTICOS E NAS PROPOSTAS DE PESQUISADORES DA ÁREA
}

\author{
"Abram a cabeça e o coração \\ para conhecer o que está além das fronteiras do aceitável, \\ para pensar e repensar, para criar novas visões. \\ Celebro um ensino que permita transgressões - \\ um movimento contra as fronteiras e para além delas. \\ É esse movimento que transforma a educação na prática da liberdade."
}

Bell Hooks

Neste capítulo, será apresentada a análise dos livros didáticos de Física e Ciências, aprovados no PNLD (Programa Nacional do Livro Didático) referente aos anos de 2018 e 2017. Para isso, contamos com a análise de doze coleções de Física (36 livros) e doze coleções de Ciências (48 livros), totalizando uma amostra de 84 livros analisados. Desta forma, o objetivo por fazer uma análise mais detalhada deste material com relação a Astronomia cultural se deu pelo fato do livro didático ser um elemento cultural importante e, por isso, no Brasil acaba por ser muitas vezes o único material disponível para alunos e professores (BITTENCOURT, 2003; SIMÕES, 2008).

Vale ressaltar que para esta análise, usamos como referencial metodológico a Análise de Conteúdo (MORAES, 1999). Foram construídas, partindo do referencial da Candau (2013), duas grandes categorias (Monocultural e Menos valorizados socialmente) para nos auxiliar na compreensão da forma como este conteúdo é apresentado nos livros.

\subsection{O livro didático como elemento cultural}

O livro didático é um instrumento pedagógico utilizado há muito tempo nos processos educacionais, ocupando espaço importante no cenário escolar e, em decorrência disto, é uma fonte complexa e rica para analisarmos as questões referentes à educação. Lhes-são atribuídas múltiplas funções, mas o livro situa-se principalmente no que diz respeito à ser

"Depositário de um conteúdo educativo, o manual tem, antes de mais nada, o papel de transmitir às jovens gerações os saberes, as habilidades (mesmo o "saber-ser") os quais, em uma dada área e a um dado momento, são 
julgados indispensáveis à sociedade para perpetuar-se." (CHOPPIN, 2002, p. 14)

Diante deste espaço ocupado por esse material, pode-se dizer que o livro ultrapassa a "simples" presença de apoio pedagógico, mas "(...) está, efetivamente, inscrito na realidade material, participa do universo cultural e sobressai-se, da mesma forma que a bandeira ou a moeda, na esfera do simbólico" (CHOPPIN, 2002, loc.cit.)

Pensar no livro didático quando refletimos sobre processos pedagógicos é quase inevitável. Não é diferente quando pensamos quanto ao seu papel ao longo da sua jornada como parte inerente do contexto escolar.

Comenius, considerado o pai da pedagogia moderna, em pleno século XVII já expunha um sistema de ensino incluindo esse tipo de material como importante veículo portador de conhecimento.

\begin{abstract}
"O papel são os discípulos cujas inteligências hão de ser impressas com os caracteres das ciências. Os tipos ou caracteres são os livros didáticos e demais instrumentos preparados para este trabalho, graças aos quais se imprime, na inteligência, com facilidade tudo quanto se há de aprender. A tinta é a voz viva do professor que traduz o sentido das coisas e dos livros para os alunos. A prensa é a disciplina escolar que dispõe e sujeita a todos para receber o ensinamento" (COMENIUS, 2011, p.364)
\end{abstract}

No Brasil, esse tipo de material também adquire papel importante. Sua importância é demonstrada desde a Reforma Pombalina (1750-1777) com o intuito de se instaurar o Novo Método - formulação de novos métodos e conteúdos destinado à docentes que seriam remunerados e de ocupação do sistema público -, deixando para trás as orientações conduzidas pela Companhia de Jesus. Desta forma, um dos pontos básicos da mudança foi a impressão de livros didáticos a serem distribuídos nas escolas régias - primeira sistematização de um sistema laico e público - e a queima de livros utilizados que propagavam o antigo método. (BITTENCOURT, 1993)

Com isso, segundo Circe Bittencourt (1993) em meados do século XVIII, o livro didático já era um dos principais instrumentos utilizados na formação de professores como forma de utilizar novas metodologias e conteúdos e, no decorrer dos anos, sua presença se instaurou ainda mais com os processos de "nacionalização" dos livros.

Com o passar dos anos, com o uso do livro didático cada vez mais frequente, as instituições de ensino acabam por torná-lo como o grande composto de verdades e, atualmente, esse material acaba por ditar a ação dos currículos escolares em sala de aula, principalmente se não há uma preparação e formação do educador para lidar 
com esse tipo de obra, tornando-o assim, o mais importante e presente instrumento pedagógico da História das Instituições Escolares (GATTI JUNIOR, 1997).

Gatti Junior (1997) ainda ressalta que os livros escolares predominam no tempo despendido pelos alunos e professores nos processos de ensino-aprendizagem e, por isso, são os principais materiais responsáveis pelos saberes difundidos no interior das escolas.

Moreira e Candau (2007) destacam que o conhecimento escolar passa por um processo de descontextualização - responsável por viabilizar os saberes e práticas tais como funcionam em seus contextos de origem - e, em seguida, uma recontextualização - transpõe os conhecimentos de referência para que se torne o conhecimento escolar. No entanto, esse processo de descontextualizar costuma fazer com que o conhecimento escolar pareça algo finalizado e engessado, sem maleabilidade para discussões e críticas, resultando numa formação em que os educandos aprendam somente os produtos, não tendo compreensão da grande complexidade que são os processos evolutivos da nossa história. Trazendo esta questão para o livro didático, para estes autores

\footnotetext{
"[os livros didáticos] não costumam incluir, entre os conteúdos selecionados, os debates, as discordâncias, os processos de revisão e de questionamento que marcam os conhecimentos e os saberes em muitos de seus contextos originais. Dificilmente encontramos, em programas e em materiais didáticos, menções às disputas que se travam, por exemplo, no avanço do próprio conhecimento científico. " (p.23)
}

Para além dos processos que descontextualizam os saberes que chegam nas escolas por meio deste material didático, podemos ressaltar que esse processo de construção do que é denominado como "conhecimento escolar" sofre efeitos das relações sociais de poder (MOREIRA; CANDAU, 2007). Essa hierarquização de saberes legitima aquilo que é socialmente reconhecido e valorizado e estigmatiza os saberes populares e saberes produzidos por grupos que são menos reconhecidos na sociedade.

A escolha por analisar os livros didáticos se justifica, pois, além de ser elemento de extrema importância para compreendermos e mapearmos aquilo que se chega na escola, este objeto de estudo adquire múltiplos papéis, que vão desde uma mercadoria como objeto de indústria, mas também, como um importante meio portador de um sistema de valores (BITTENCOURT, 2003). 
Circe Bittencourt (2003) ressalta que o livro didático tem sido o principal instrumento de trabalho utilizado por professores e alunos, além de ser o principal mediador entre o currículo proposto nos parâmetros curriculares e o conhecimento que se chega à escola. A autora ressalta que esse tipo de material possui diversas facetas, sendo uma destas a de mercadoria, que é atrelada às lógicas de mercado e comercialização, além de ser um depositário de conteúdos escolares, ou seja, é por meio desta característica que os conteúdos que chegam à escola são selecionados. O livro didático pode ser considerado também como um instrumento pedagógico, que produz uma gama de técnicas e sugestões de como determinado conteúdo deve ser ensinado.

Uma das características mais importantes (ao nosso ver) citada por Circe, é que o livro didático é "veículo portador de um sistema de valores, de uma ideologia, de uma cultura" (BITTENCOURT, 2003, p.72).

\footnotetext{
"Estudar, por exemplo, a imagem que os manuais americanos apresentam dos Negros, apreende-se bem mais sobre a sociedade americana contemporânea que sobre os próprios Negros, pois o discurso sobre o Outro remete uma certa imagem daquele que a tem. " (CHOPPIN, op.cit, p.22)
}

É nessa perspectiva que nos deparamos com a importância da análise deste tipo de material pois, diversas pesquisas demonstram que muitas obras transmitem maior valorização de grupos dominantes, estereótipos, generalização de temas com base da sociedade branca burguesa e, complementando, ao nosso ver, ocidental. Afinal, as escolhas da apresentação do livro como um todo não são neutras. As presenças e ausências são indicativos importantes, como aponta Choppin (2002) ao afirmar que "existe dos manuais uma leitura em negativo! " (Ibidem, p.22)

\subsection{Metodologia e Definição do corpus de análise}

Os livros didáticos de Ciências e Física desta seção foram escolhidos por serem os materiais mais recentemente aprovados no Programa Nacional do Livro Didático (PNLD) de 2017 e 2018, respectivamente. Esta análise foi realizada por meio da análise de conteúdo (MORAES, 1999). Os livros foram analisados em detalhes, envolvendo textos, imagens, exercícios e manual do professor. Realizamos essa análise, buscando compreender de que forma e qual a frequência que o tema da astronomia cultural vem sendo levado para as escolas da sociedade contemporânea, 
uma vez que, como já ressaltado, o livro didático é um veículo importante entre o que é proposto no currículo e o conhecimento (e saberes) que chegam à sala de aula.

O corpus da análise de livros didáticos é composto por doze coleções relacionadas com a Física e doze coleções de Ciências.

As obras de Física consideradas resumem-se em coleções compostas por três livros cada uma e todos os livros possuem em seu sumário ao menos um capítulo dedicado a conteúdos de astronomia. Algumas destas, apresentam grandes unidades para explorar o tema, envolvendo muitas vezes a história da astronomia, viés artístico como, por exemplo, obras de arte e o desenvolvimento do trabalho científico.

Vale ressaltar que os livros foram analisados e explorados em sua totalidade, considerando-se toda a parte textual, de imagens, exercícios propostos e resolvidos, boxes e manual do professor.

Além da análise dos capítulos ou unidades relacionadas exclusivamente com a área da astronomia, exploramos também as unidades que abordam temas como a origem do universo e a construção do conhecimento científico, uma vez que, como percebido, há elementos de diversas culturas que são importantes para compor a análise das obras como um todo.

Os livros de física aprovados no PNLD que compõem a amostra encontram-se na Tabela 06, a seguir.

Tabela 6: Catálogo de livros de Física - PNLD 2018.

\begin{tabular}{|c|c|c|c|}
\hline COLEÇÃO & TÍTULO DA OBRA & AUTOR & EDITORA \\
\hline 1 & Física & $\begin{array}{l}\text { Bonjorno, Clinton, Eduardo Prado, } \\
\text { Casemiro }\end{array}$ & FTD \\
\hline 2 & Física aula por aula & Benigno Barreto, Claudio Xavier & FTD \\
\hline 3 & Física & $\begin{array}{c}\text { Ricardo Helou, Gualter Biscuola e } \\
\text { Newton Villas Bôas }\end{array}$ & $\begin{array}{l}\text { Saraiva (Somos } \\
\text { Educação) }\end{array}$ \\
\hline 4 & $\begin{array}{c}\text { Física para o Ensino } \\
\text { Médio }\end{array}$ & Luiz Felipe Fuke e Kazuhito Yamamoto & $\begin{array}{l}\text { Saraiva (Somos } \\
\text { Educação) }\end{array}$ \\
\hline 5 & Física & Guimarães, Piqueira e Carron & $\begin{array}{l}\text { Ática (Somos } \\
\text { Educação) }\end{array}$ \\
\hline
\end{tabular}


6

Física - Contexto e

Antônio Máximo, Beatriz Alvarenga e

Ática (Somos

Aplicações

Carla Guimarães

Educação)

\begin{tabular}{|c|c|c|c|}
\hline 7 & $\begin{array}{l}\text { Compreendendo a } \\
\text { Física }\end{array}$ & Alberto Gaspar & $\begin{array}{l}\text { Ática (Somos } \\
\text { Educação) }\end{array}$ \\
\hline 8 & Física em contextos & $\begin{array}{c}\text { Maurício Pietrocola, Talita Raquel } \\
\text { Romero, Alexander Pogibin, Renata de } \\
\text { Andrade }\end{array}$ & Editora do Brasi \\
\hline 9 & $\begin{array}{l}\text { Ser Protagonista - } \\
\text { Física }\end{array}$ & $\begin{array}{c}\text { Adriana Benetti Marques Válio, Ana } \\
\text { Fukui, Bassam Ferdinian, Gladstone } \\
\text { Alvarenga de Oliveira, Madson de Melo } \\
\text { Molina }\end{array}$ & Edições SM \\
\hline 10 & $\begin{array}{l}\text { Conexões com a } \\
\text { Física }\end{array}$ & $\begin{array}{c}\text { Glorinha Martini, Walter Spinelli, Hugo } \\
\text { Carneiro Reis, Blaidi Sant'Anna }\end{array}$ & $\begin{array}{l}\text { Moderna (Grupo } \\
\text { Santillana) }\end{array}$ \\
\hline 11 & $\begin{array}{l}\text { Física - Ciência e } \\
\text { Tecnologia }\end{array}$ & $\begin{array}{c}\text { Carlos Magno A. Torres, Nicolau } \\
\text { Gilberto Ferraro, Paulo Antonio de } \\
\text { Toledo Soares, Paulo Cesar Martins } \\
\text { Penteado }\end{array}$ & $\begin{array}{l}\text { Moderna (Grupo } \\
\text { Santillana) }\end{array}$ \\
\hline 12 & $\begin{array}{l}\text { Física - Interação e } \\
\text { Tecnologia }\end{array}$ & $\begin{array}{c}\text { Aurelio Gonçalves Toscano, Carlos } \\
\text { Toscano }\end{array}$ & Leya \\
\hline
\end{tabular}

Fonte: Oliveira, 2020

$\mathrm{Na}$ tentativa de mapear como a temática da diversidade na perspectiva intercultural (CANDAU, 2013) está presente e valorizada nos livros didáticos de física aprovados no PNLD 2018, analisamos as 12 coleções em busca das diversas produções do conhecimento em múltiplas culturas como, por exemplo, a astronomia indígena, oriental e outras.

Com a intenção de se obter um maior panorama da presença dos temas culturais que têm relação com a Astronomia nos livros didáticos, analisou-se também os livros de Ciências aprovados no PNLD de 2017. Além de situar a pesquisa no cenário contemporâneo, com a análise destes livros, podemos perceber de que forma a temática vem sendo trabalhada desde os anos do ensino fundamental, até se chegar nos conteúdos de Física do Ensino Médio.

No caso dos livros de Ciências, temos 13 coleções aprovadas no ano de 2017. As obras consideradas nesta amostragem resumem-se em coleções compostas por 
quatro livros cada uma, que vão desde o $6^{\circ}$ ano do fundamental II, até os livros do 9ำ ano.

Os livros de Ciências aprovados no PNLD de 2017 encontram-se abaixo na Tabela 07.

Tabela 7: Catálogo de livros de Ciências - PNLD 2017

\begin{tabular}{|c|c|c|c|}
\hline COLEÇÃO & LIVRO & AUTOR & EDITORA \\
\hline 1 & $\begin{array}{l}\text { Aprendendo com o } \\
\text { Cotidiano }\end{array}$ & Eduardo Leite do Canto & Moderna \\
\hline 2 & Universos & $\begin{array}{c}\text { Org: Edições SM. Ed. responsável: } \\
\text { Lia Monguilhott Bezerra }\end{array}$ & SM \\
\hline 3 & $\begin{array}{l}\text { Investigar e } \\
\text { Conhecer }\end{array}$ & Sônia Lopes & Saraiva Educação \\
\hline $4^{\star}$ & $\begin{array}{l}\text { Companhia das } \\
\text { Ciências }\end{array}$ & $\begin{array}{c}\text { João Usberco - José Manoel Martins } \\
\text { - Luis Carlos Ferrer - Herick Martin } \\
\text { Velloso - Eduardo Schechtmann }\end{array}$ & Saraiva Educação \\
\hline 5 & Ciências & $\begin{array}{l}\text { Carlos Kantor - José Trivellato - } \\
\text { Júlio Foschini Lisboa - Marcelo } \\
\text { Motokane - Silvia Trivellato }\end{array}$ & Quinteto \\
\hline 6 & Novo Pensar & Demétrio Gowdak - Eduardo Martins & FTD \\
\hline 7 & Para Viver Juntos & $\begin{array}{c}\text { Org: Edições SM. Ed. Responsável: } \\
\text { Lia Monguilhott Bezerra }\end{array}$ & SM \\
\hline 8 & Ciências & Carlos Barros - Wilson Paulino & Ática \\
\hline 9 & Tempo de Ciências & $\begin{array}{l}\text { Org: Editora do Brasil. Ed. } \\
\text { Responsável: Angela Sillos e } \\
\text { Eduardo Passos }\end{array}$ & Editora do Brasil \\
\hline 10 & Projeto Teláris & Fernando Gewandsznajder & Ática \\
\hline 11 & $\begin{array}{c}\text { Projeto Araribá - } \\
\text { Ciências }\end{array}$ & Maíra Rosa Carnevalle & Moderna \\
\hline $12^{\star}$ & $\begin{array}{l}\text { Projeto Apoema - } \\
\text { Ciências }\end{array}$ & $\begin{array}{c}\text { Ana Maria Pereira - Ana Paula } \\
\text { Bemfeito - Carlos Eduardo - } \\
\text { Margarida Santana - Mônica } \\
\text { Waldhelm }\end{array}$ & Editora do Brasil \\
\hline 13 & Jornadas. cie & Isabel Rebelo Roque & Saraiva Educação \\
\hline
\end{tabular}

${ }^{*}$ Foram analisados somente os livros do Aluno

Fonte: Oliveira, 2020 
O PNLD correspondente ao ano de 2017 distribuiu um total de $10.789 .373^{5}$ exemplares de livros de ciências e, para esta análise, 12 das 13 coleções mais distribuídas foram analisadas. Essa escolha foi feita, pois percebemos uma dificuldade em ter acesso à última coleção distribuída. Porém, acreditamos que a amostra utilizada pode apresentar um bom espectro da inserção da temática na escola brasileira, uma vez que contabiliza uma quantia de 10.692 .504 livros, o equivalente a aproximadamente $99 \%$ do total de exemplares distribuídos. Os números correspondentes à distribuição de cada livro, encontra-se na tabela abaixo.

Tabela 8: Distribuição dos livros de Ciências do PNLD referente ao ano de 2017

\begin{tabular}{ccc}
\hline $\begin{array}{c}\text { Ordem da } \\
\text { distribuição }\end{array}$ & Coleção & $\begin{array}{c}\text { Quantidade de } \\
\text { exemplares }\end{array}$ \\
$\mathbf{1}$ & Teláris & 2.598 .258 \\
$\mathbf{2}$ & Araribá & 1.702 .220 \\
$\mathbf{3}$ & Investigar e Conhecer & 1.276 .812 \\
$\mathbf{4}$ & Companhia das Ciências & 1.120 .482 \\
$\mathbf{5}$ & Aprendendo com o & 971.831 \\
$\mathbf{6}$ & Cotidiano & 717.255 \\
$\mathbf{7}$ & Ciências - Novo Pensar & 605.859 \\
$\mathbf{8}$ & Projeto Apoema & 490.838 \\
\hline $\mathbf{9}$ & Ciências & 378.266 \\
\hline $\mathbf{1 0}$ & Tempo de Ciências & 372.980 \\
$\mathbf{1 1}$ & Para Viver Juntos & 333.279 \\
$\mathbf{1 2}$ & Ciências & 124.424 \\
$\mathbf{1 3}$ & Universos & 96.869 \\
\hline
\end{tabular}

Todas as obras desta amostra também foram analisadas e exploradas em sua totalidade. Vale completar que algumas destas obras apresentam grandes unidades para explorar a Astronomia, envolvendo muitas vezes temas de Geologia como, por exemplo, a estrutura da Terra e a história da astronomia.

Todos os livros (Física e Ciências) foram analisados por meio de duas grandes categorias de análise, que foram criadas a partir dos termos utilizados por Candau (2013), sendo elas : "Monocultural" e "Menos valorizados socialmente". Além disso, para cada uma delas, criamos subcategorias que agrupam os elementos que possuem a mesma estrutura/forma de como a astronomia cultural é apresentada nos

\footnotetext{
${ }^{5}$ http://www.fnde.gov.br/index.php/programas/programas-do-livro/pnld/dados-estatisticos
} 
livros. Desta forma, não houve uma preocupação com os conteúdos propriamente ditos, apesar de haver uma certa constância dos temas (constelações e origem do universo, principalmente).

A primeira categoria engloba tudo de astronomia que é exposto do conhecimento produzido pela cultura dominante, sendo ela, a ciência ocidental branca composta por grandes gênios - "donos do conhecimento científico". Nesta categoria, incluímos os livros que colocam os gregos e egípcios como precursores de todo o desenvolvimento científico e astronômico, pois, por mais que consideremos as culturas grega e egípcia, ambas se englobam no conhecimento tradicional e etnocêntrico. Afinal, sabemos que não são só essas culturas que observavam, registravam e conheciam o céu, tampouco, responsáveis por todos os saberes.

Ainda dentro desta perspectiva, fez-se uma subdivisão para aqueles livros que, apesar de mostrarem apenas essa visão de mundo, apresentam seus conteúdos com relação ao desenvolvimento astronômico realizado por aspectos históricos e matemáticos. Nessa subdivisão, a primeira subcategoria " Abordagem Histórica", agrupa os livros que abordam a história da astronomia da maneira clássica, usando, por exemplo, Copérnico, Ptolomeu, Galileu e Kepler, como únicos precursores desse conhecimento. A segunda subcategoria, denominada "Formulações matemáticas" reúne aqueles livros que trazem à tona o conhecimento da astronomia, principalmente por meio de conceitos e relações matemáticas - Leis de Kepler e Lei da Gravitação Universal, por exemplo.

Por último, a segunda grande categoria inclui todos os grupos que são socialmente desvalorizados por seus conhecimentos acerca da ciência, sendo eles os indígenas, árabes, orientais e outros.

Para a categoria "Menos Valorizados socialmente", algumas subdivisões foram feitas. A primeira subcategoria, denominada "Narrativas", engloba os textos que aparecem nos livros que tanto são escritos por autores/autoras terceiros, quanto pelos autores/autoras do próprio livro didático. Essas narrativas podem também ser tanto de fontes etno-históricas, quanto descritivas de alguma concepção de uma determinada cultura. Vale ressaltar que, por não encontrarmos um número representativo de cada um destes elementos, optamos por mantê-los em uma mesma subcategoria que agrupe todas as narrativas encontradas. O segundo grupo, denominado "Comparativo" apresenta elementos que estão presentes nos livros, que trazem uma comparação ou analogia entre a cultura ocidental e uma outra 
(geralmente de algum grupo que epistemologicamente não é valorizado). Essa comparação pode aparecer por meio de questões, pesquisas ou qualquer outra forma, desde que, encontremos em sua centralidade um elemento de comparação entre as culturas e/ou concepções. Por último, a subcategoria denominada "Outros", trabalha com os elementos que envolvem a temática da pesquisa, mas que são elementos muito pontuais que, ou são insuficientes para uma análise mais profunda (como a legenda de imagem ou somente uma imagem solta no livro) ou que não conversam com os outros elementos das outras categorias. É importante ressaltar que, por ser uma temática pouco encontrada nesse material, alguns elementos são muito específicos em determinadas coleções, não sendo possível criar uma categoria que contemple todas essas especificidades.

Desta forma, a esquematização das categorias pode ser representada como na figura abaixo.

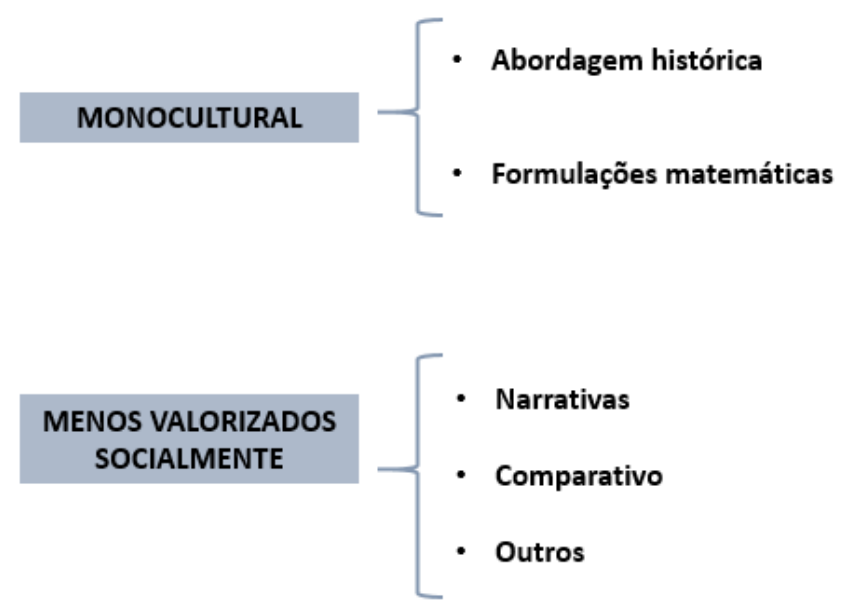

Figura 1: Representação das categorias com relação aos livros didáticos.

Fonte: Oliveira, 2020

\subsection{Astronomia Cultural nos Livros Didáticos: Análise e resultados}

Com o intuito de traçar as características gerais dos materiais em busca da diversidade cultural presente na temática da astronomia, percebemos por meio da análise, certa constância em relação aos temas abordados dentro dos capítulos/setores que abordam a temática. 
Foi possível perceber também que alguns temas são mais propícios a ter um viés cultural nesses livros. Por exemplo, algumas coleções apresentam em seus capítulos iniciais as primeiras visões de mundo, origem do universo e construção do método científico, em que apresentam elementos/olhares de outras culturas para além da concepção ocidental.

Com essa análise, em busca de elementos que exploram a diversidade presente nos livros por meio das categorias e subcategorias citadas, apresentamos, a seguir, nossos principais resultados. Vale ressaltar que, qualquer livro que apresentasse um conteúdo de grupos subalternos, já foi incluído na segunda categoria.

\subsubsection{Livros Didáticos de Física}

Antes de apresentarmos em detalhes os resultados, representamos a seguir o gráfico dos resultados das categorias referentes aos livros de Física do PNLD 2018. Neste primeiro gráfico, representamos os resultados por coleção, ou seja, incluiu-se na categoria "Menos valorizados socialmente" as coleções que tivessem pelo menos um de seus livros com um viés cultural pertencente à esses grupos.

Gráfico 2: Resultados das coleções de Física por categoria.

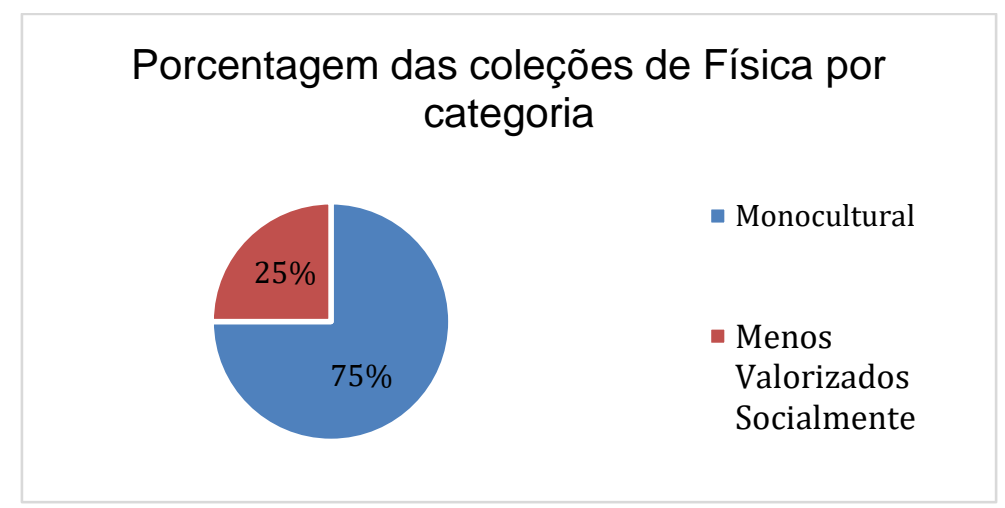

Fonte: Oliveira, 2020.

No segundo gráfico apresentamos o resultado por livro didático. É possível perceber uma diferença percentual quando restringimos o resultado livro a livro. 
Gráfico 3: Resultados dos livros didáticos de Física por categoria.

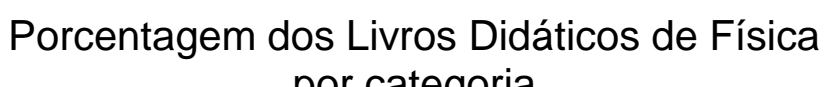

por categoria

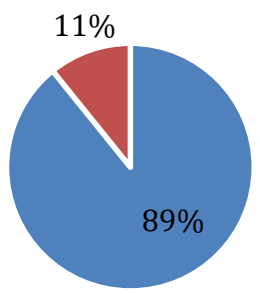

- Monocultural

- Menos Valorizados

Socialmente

Fonte: Oliveira, 2020.

A distribuição de cada livro para cada uma das duas grandes categorias encontra-se na tabela a seguir. Nela, percebemos que parte dos livros de Física aborda o conteúdo de astronomia no primeiro livro do ensino médio, outros - uma minoria - no livro referente ao segundo ano. Para o segundo ano, o tema de Eclipses é o mais recorrente e para os livros do terceiro ano, nada foi encontrado. A tabela a seguir apresenta a distribuição dos livros de Física de acordo com as duas grandes categorias.

Tabela 9: Distribuição dos livros didáticos de Física por categoria

\begin{tabular}{|c|c|c|c|c|}
\hline \multirow[b]{2}{*}{ Coleções } & \multicolumn{2}{|c|}{ Monocultural } & \multicolumn{2}{|c|}{ Menos valorizados socialmente } \\
\hline & L1 & L2 & L1 & L2 \\
\hline 1 & $x$ & $\mathrm{x}$ & & \\
\hline 2 & & & $x$ & \\
\hline 3 & $x$ & $x$ & & \\
\hline 4 & & & $x$ & $x$ \\
\hline 5 & $x$ & & & \\
\hline 6 & $x$ & & & \\
\hline 7 & $x$ & $x$ & & \\
\hline 8 & & & $x$ & \\
\hline 9 & $x$ & & & \\
\hline 10 & $x$ & $x$ & & \\
\hline 11 & $x$ & & & \\
\hline 12 & $x$ & & & \\
\hline
\end{tabular}




\section{Categoria "Monocultural"}

Nesta categoria, agrupam-se as coleções 1, 3, 5, 6, 7, 9,10, 11, 12, totalizando nove das doze coleções analisadas. Destas nove coleções, treze livros abordam astronomia e foram selecionados para uma análise mais profunda e se encaixam nas subcategorias: Abordagem histórica e Formulações matemáticas.

Todos os treze livros apresentam o conhecimento astronômico produzido pelos viés histórico-cultural dos cientistas precursores da ciência européia ocidental.

Tratando das subcategorias, encontramos que oito livros apresentam o desenvolvimento destes conhecimentos por meio do desenvolvimento histórico da Astronomia, os outros cinco livros utilizam, preferencialmente, de formulações matemáticas para o desenvolvimento da temática.

Tabela 10: Distribuição dos livros de Física na categoria Monocultural

\begin{tabular}{|c|c|c|c|c|}
\hline \multirow[b]{3}{*}{ Coleções } & \multicolumn{4}{|c|}{ Categoria Monocultural } \\
\hline & \multicolumn{2}{|c|}{ Abordagem Histórica } & \multicolumn{2}{|c|}{ Formulação matemática } \\
\hline & L1 & $\mathbf{L} 2$ & L1 & L2 \\
\hline 1 & $x$ & $x$ & & \\
\hline 3 & $x$ & $x$ & & \\
\hline 5 & & & $x$ & \\
\hline 6 & & & $x$ & \\
\hline 7 & $x$ & & & $x$ \\
\hline 9 & $x$ & & & \\
\hline 10 & & $x$ & $x$ & \\
\hline 11 & $x$ & & & \\
\hline 12 & & & $x$ & \\
\hline
\end{tabular}

Sobre a subcategoria "Abordagem Histórica", muitos destes livros iniciam as explicações da história da astronomia com um vocábulo do tipo "nossos antepassados" ou "muitas civilizações" se referindo, geralmente, ao povo grego e egípcio e, também, trazendo as figuras de Ptolomeu e Aristóteles à tona como pontapé inicial para o desenvolvimento da história do conhecimento do céu.

Abaixo, mostramos alguns dos dados coletados para compor essa categoria. 


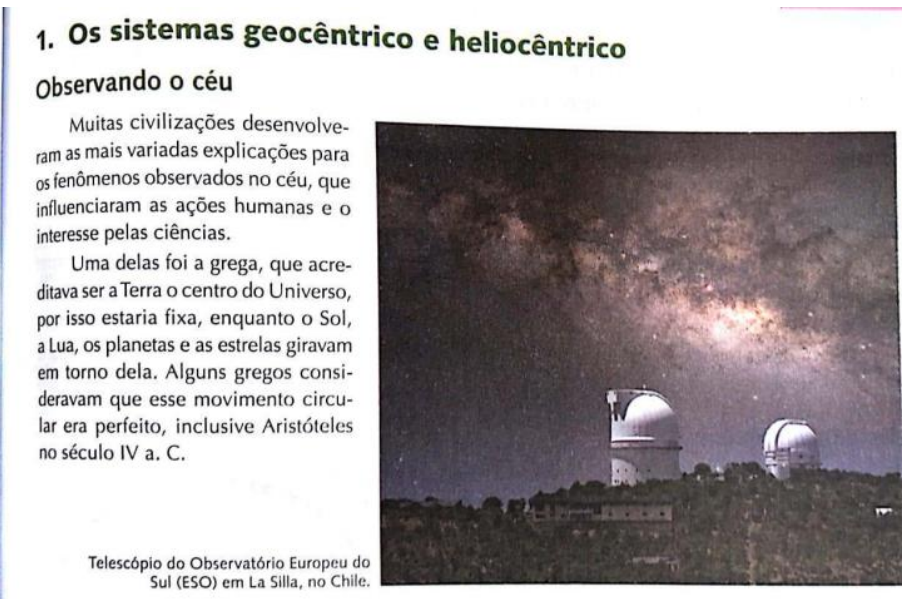

Figura 2: Introdução do capítulo de “Gravitação universal” na coleção 01.

Fonte: Bonjorno, Clinton, Casemiro, p.201, 2016.

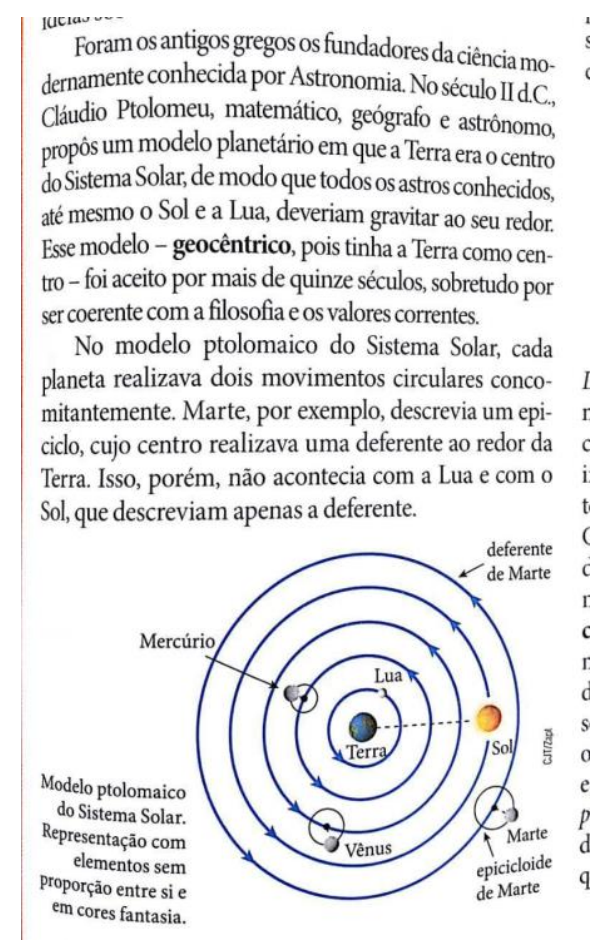

Figura 3: Início do capítulo de "Gravitação" da coleção 03.

Fonte: Helou; Biscoula; Villas Bôas, p.145, 2016.

Na coleção de número 3, a visão "monocultural " é bem marcante. Vemos que o livro se dedica a apresentar todo o conteúdo astronômico por meio de uma histórica clássica eurocêntrica. O material apresenta o aspecto histórico que envolve a construção do pensamento astronômico, falando brevemente dos gregos como os "fundadores da ciência modernamente conhecida por Astronomia." (Figura 03), além 
das mudanças de modelo geocêntrico e heliocêntrico serem centradas nas figuras de Ptolomeu, Copérnico, Galileu, Kepler e Newton.

A coleção de número 10, apesar de apresentar o desenvolvimento da astronomia de modo tradicional, em seu segundo livro, ao tratar do tópico de Eclipses, sugere a seguinte atividade seguida da respectiva orientação do Manual do Professor:

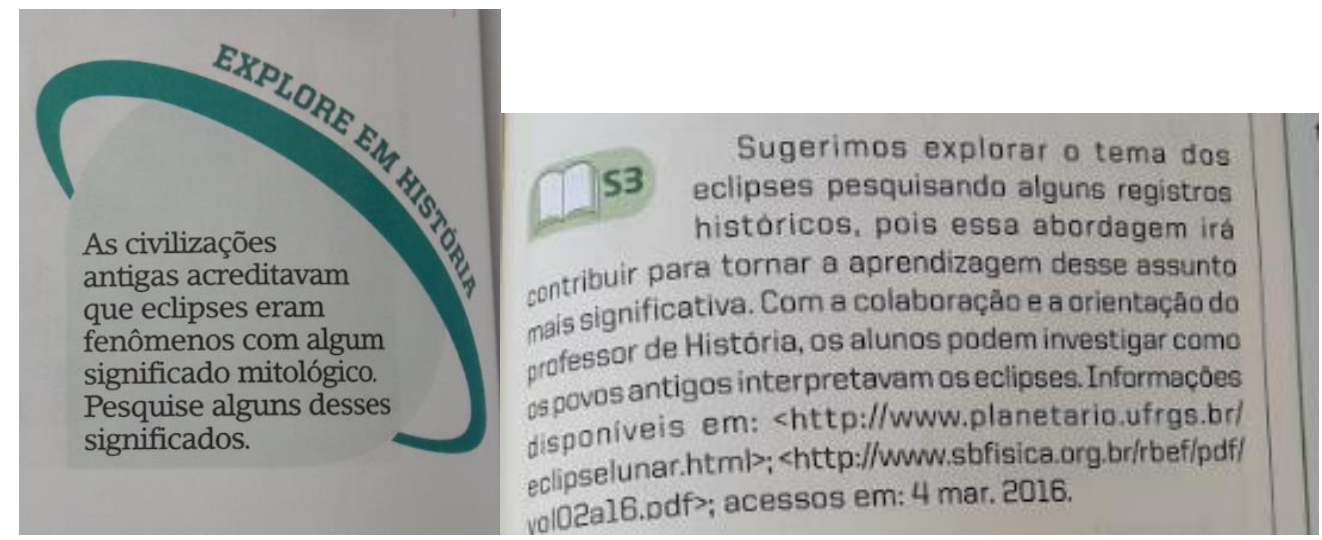

Figura 4: Tópico de Eclipses e orientação do Manual do professor. Ambos referentes à coleção 10 .

Fonte: Martini et al, p. 144 e 339, 2016.

Um ponto que podemos destacar quanto à estrutura desta atividade, é que ela se encontra em formato de "box", não fazendo parte do setor "Atividades", dando-nos a entender que é algo que pode ou não ser explorado. Analisando o que o enunciado propõe, há a possibilidade de se tratar de outras culturas e das razões dos eclipses terem vínculos com seus significados mitológicos. Todavia, quando olhamos a orientação oferecida para o professor, percebemos que a atividade não explora a gama de possibilidades que o assunto tem quando levado para a sala de aula. Os valores da tolerância e respeito acerca das diversas interpretações do fenômeno dos eclipses não são citados pelos autores do livro.

Com relação aos livros que trazem à tona a subcategoria "Formulações matemáticas" destacamos os livros do primeiro ano das coleções 5, 6, 10 e 12, e o livro do segundo ano da coleção 7 . Os livros que se encontram nessa categoria trazem o estudo da astronomia resumido em "Leis de Kepler" e "Lei da Gravitação Universal", com suas respectivas fórmulas e breves explicações das mesmas.

A seguir, mostramos o que a coleção 12 nos apresenta sobre as Leis de Kepler que abre a seção de astronomia do livro do $1^{\circ}$ ano. 
Primeira lei: Um planeta se move descrevendo uma elipse e tendo o Sol como um dos focos (figura 3 ).

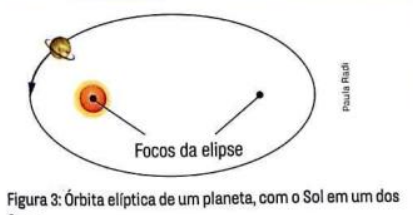

$$
\text { Figura 3: Órbita eliptica de um planeta, como Sol em um dos }
$$

Segunda lei: A linha que liga o Sol ao planeta "varre" áreas iguais em intervalos de tempo também iguais (figura 4)

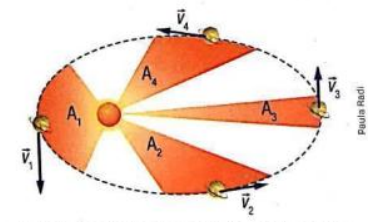

Figura 4: Áreas formadas pela linha que liga o Sol ao planeta, enquanto este orbita em torno do Sol. Para um mesmo intervalo de tempo, $A_{2}=A_{2}=A_{2}=A_{c}$.

Terceira lei: É constante, para todos os planetas, a razão entre o tempo (T) que um planeta leva para dar uma volta completa em torno do Sol elevado ao quadrado e o raio médio $(r)$ de sua órbita elevado ao cubo.

\section{$\frac{T^{2}}{r^{3}}=\mathrm{k}$, em que $\mathrm{k} e ́$ uma constante.}

Figura 5: Leis de Kepler na coleção 12.

Fonte: Toscano; Toscano, p.91, 2016.

Na coleção de número 6, como vemos na imagem a seguir, apresenta a história da astronomia reduzida a dois parágrafos e logo em seguida já encontramos as Leis de Kepler. 


\section{1}

\section{Astronomia e gravitação}

A Astronomia é a mais antiga das ciências. A quantidade e a precisão dos dados astrionom miluência que os fenômenos celestes exerciamente surpreendentes. Isso se devéa in Anecessidade as posiçōes do sol, da Lua edas estrelas levaram os astrônomos da Antiguidade as um grande númedo dados sobre os movimentos dos astros. Ba ${ }^{2}$ lea lise desses dados, os astrônomos elaboraram modelos para auxilar a interprea andilis movimento dos objetos celestes.

A distribuição dos astros no céu sempre foi uma temática abordada pelos mais diversos povos. Os regristóteles antigos do modelo do Universo são da época dos gregos, defendido por Aristóteles. Segundo esse modelo, a Terra era o centro do Universo, o 501 , as estrelas e os demais planetas giravam em torno dela - sistema conhecido como geoêntrico e que dominou o pensamento filoséfico na Europa ate o sciclo xvi. Nesse século, Copérnico apresentou seu modelo, conhecido como modelo heliostático, em que o Sol estava parado no centro do sistema e os planetas, incluindo a Terra, giravam em torno dele em órbitas circulares. As hipóteses de Copérnico e os dados colhidos por Tycho Brahe constituiram a base do trabalho de johannes Kepler.

\subsection{As leis de Kepler}

primeira lei de Kepler

A correção do sistema de Copérnico, procurada por Kepler, é expressa por sua primeira lei. Seus estudos o levaram a concluir que, realmente, os planetas se movem em torno do Sol, mas suas órbitas sảo elipticas e não circulares, como supunha Copérnico. Além disso, Kepler verificou que o Sol está em um dos focos da elipse (figura 6.1). Note que a órbita de um planeta não é uma elipse tảo alongada. As órbitas pouco diferem de uma circunferência; veja a tabela 6.1, onde são comparados os valores do ferem de uma circunferência; veja a tabela 6.1, onde são comparados os valores do
semieixo maior com os do semieixo menor. Kepler descobriu que as órbitas são elipses graças às cuidadosas observaçōes astronômicas realizadas por Tycho Brahe.

A quinta coluna da tabela 6.1 mostra as excentricidades das órbitas dos planetas do Sistema Solar. A excentricidade (e) é um parâmetro que mede o afastamento de uma órbita da forma circular. Se $e=0$ temos uma órbita circular; se $0<e<1$ temos uma órbita elíptica. Note que as excentricidades dos planetas da tabela 6.1 săo muito pequenas, o que significa que as órbitas são quase circulares. A órbita do planeta Mercúrio é a mais achatada.

Tabela 6.1

Dados das Óroitas dos pLanetas do Sistema SOLAR

Planeta Periodo de Semieixo maior ou $T^{2} / r^{3}$
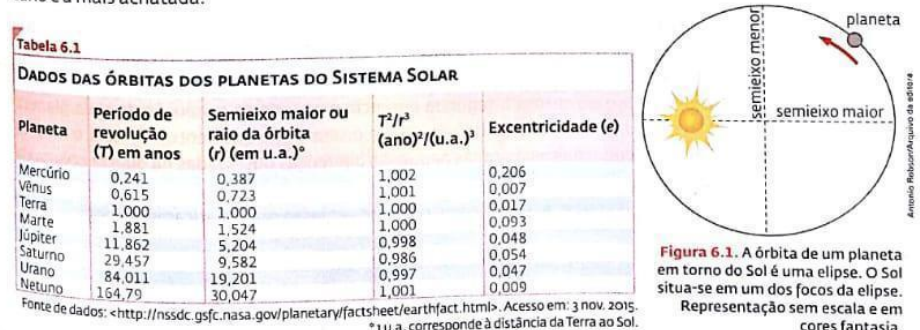

GRAVITAÇAO UNIVERSAL CAPITULO 6

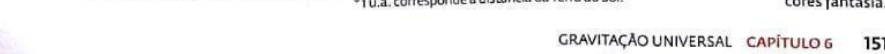

Figura 6: Capítulo dedicado a astronomia na coleção 06.

Fonte: Máximo, Alvarenga, Guimarães, p.151, 2016.

\section{Categoria "Menos valorizados socialmente"}

Das doze coleções analisadas, somente três delas se encaixam nesta segunda perspectiva. Aqui, encontram-se os livros que, de alguma forma, trazem elementos das culturas menos visibilizadas dentro do contexto social e científico. Ainda nesta classificação, faz-se três subcategorias: A primeira, denominada de "Narrativas" abarca os conhecimentos dedicados aos povos indígenas e outras culturas, por meio de textos gerais. A segunda, denominada "Comparativo", agrupa elementos do livro que trazem a comparação de culturas que são subalternas com a cultura ocidental. 
Por último, a subcategoria "Outros" traz de forma geral, outras representações e conteúdos sobre diversas culturas, mas que aparecem de forma muito pontual e sucinta nos livros, ficando descontextualizados de outras possíveis categorias.

Ao tratarmos destes conteúdos de culturas menos visibilizadas presentes nos livros de Física, a temática só se encontra nas coleções 2, 4 e 8 que, por sua vez, apresentam estes conteúdos em seções do livro sobre diferentes interpretações do céu, origem do Universo e constelações pertencentes a estes grupos.

A tabela abaixo traz a relação dos livros com as respectivas subcategorias.

Tabela 11: Distribuição dos livros de Física na categoria Menos Valorizados Socialmente

\begin{tabular}{ccccccc}
\hline \multicolumn{8}{c}{ Categoria "Menos Valorizados Socialmente" } \\
Coleções & L1 & L2 & L1 & L2 & L1 & L2 \\
2 & $x$ & & $x$ & & & \\
4 & & $x$ & & & $x$ \\
8 & $x$ & & & $x$ & \\
\hline
\end{tabular}

Sobre a subcategoria "Narrativas" percebemos que a maior parte dos livros traz o envolvimento da temática por meio desta representação no livro, uma vez que, incluímos aqui, textos que envolvem a descrição das percepções destas culturas acerca do céu. Dentre as narrativas que encontramos, pode-se dizer que elas aparecem tanto pelas palavras dos autores e autoras dos livros, mas também, como forma de textos de terceiros - geralmente, usa-se referências da área.

O conhecimento árabe pode ser encontrado na coleção 2. Nesta coleção, especificamente, uma parte do primeiro capítulo do livro 1, é dedicado ao método científico. O que nos chama a atenção é que os autores apresentam neste tópico a explicação do termo "epistemologia" e o início das formas de se pensar em Ciência por meio do mundo islâmico. Desta forma, trazem no texto o nome de três cientistas árabes e suas contribuições para este estudo, mas não há nenhum debate, atividade ou orientação no caderno do professor que promova a valorização deste conhecimento, do quanto o conhecimento desta cultura não é estudado mundialmente e as relações de poder para que esse preconceito e desvalorização da cultura árabe ocorra. 
Uma mudança nessá perspectiva começou a se manifestar por volta do ano 1000. Enquanto a Europa entrava em um período em que a Ciência estava ligada à Igreja, no mundo islâmico vários pensadores conseguiram estruturar um pouco melhor a forma de se pensar a Ciência. Podemos citar, por exemplo, o árabe Ibn al-Haytham (965-1040), que conduziu suas pesquisas de forma semelhante ao que chamamos hoje de método científico.

Segundo ele, era necessário realizar observações e experimentações sistemáticas e controladas para se conseguir descrever um problema. Deveria ser possível testar as ideias sobre ele, interpretar os dados obtidos e, por meio deles, tentar obter uma possível conclusão. Outro árabe, Abu al-Biruni (973-1048), aperfeiçoou o procedimento compreendendo que os observadores podem inserir erros na tomada de dados e que isso poderia ser corrigido pelas repetições dos testes. Já Ishaq al-Rahwi (854-931) propôs a revisão coletiva dos trabalhos e experimentos, e Abu Jabir Hayyan (721-815) introduziu a noção de experimentação controlada.

Figura 7: Conteúdo da ciência desenvolvida pelo povo árabe presente na coleção 02.

Fonte: Barreto; Xavier, p.17, 2016.

No segundo livro da coleção 4, encontramos um conteúdo do conhecimento indígena também. Neste livro, há um "box" denominado "As constelações indígenas brasileiras" que apresenta um texto de Germano Afonso e traz algumas imagens de constelações (Homem velho, Ema e Anta do Norte) que complementam o texto. Apesar do texto ser didático, trazendo elementos da cultura indígena brasileira e suas formas de conceber o céu, a atividade que se segue não faz correspondência direta ao texto.

\section{Organizando as ideias do texto}

O texto relata algumas caracteristicas da leitura do céu que fizeram os primeiros habitantes sul-americanos e australianos. Observe que, apesar das diversas circunståncias que cercam o distanciamento dessas tribos, a organizaçăo cosmológica parece ser a mesma. Outras similaridades ocorrem, não apenas entre indigenas: a faixa da nossa galáxia, que vemos no céu, foi igualmente interpretada como um caminho pelas mais diversas culturas, desde os gregos antigos. Mais intrigante ainda é o conhecimento do povo Dogon, antigos habitantes do Mali, na Africa Oriental: missōes francesas, em visita aos dogons desde 1931, declararam que esse povo cultivava uma complexa cosmologia e conhecimentos que a comunidade cientifica só comprovaria recentemente, como o fato de a estrela Sirius B ser na verdade um sistema binário, em que a estrela oculta é uma ană branca.

1. Uma vez que o conhecimento pode ser transmitido de modo formal ou não, a que você atribui essas aparentes coincidências? Professor, veja Orientaçōes Didáticas

Figura 8: Conteúdo presente na coleção 04 sobre constelações indígenas brasileiras.

Fonte: Yamamoto; Fuke, 2016, p.124.

Na coleção 8, há uma página em que os autores trazem o tópico "Cosmologias indígenas brasileiras". Podemos encontrar um texto sobre o mito kayapó que aborda a origem do mundo. A figura a seguir, apresenta a página desta atividade. 


\section{PESQUISE, PROPONHA E DEBATA}

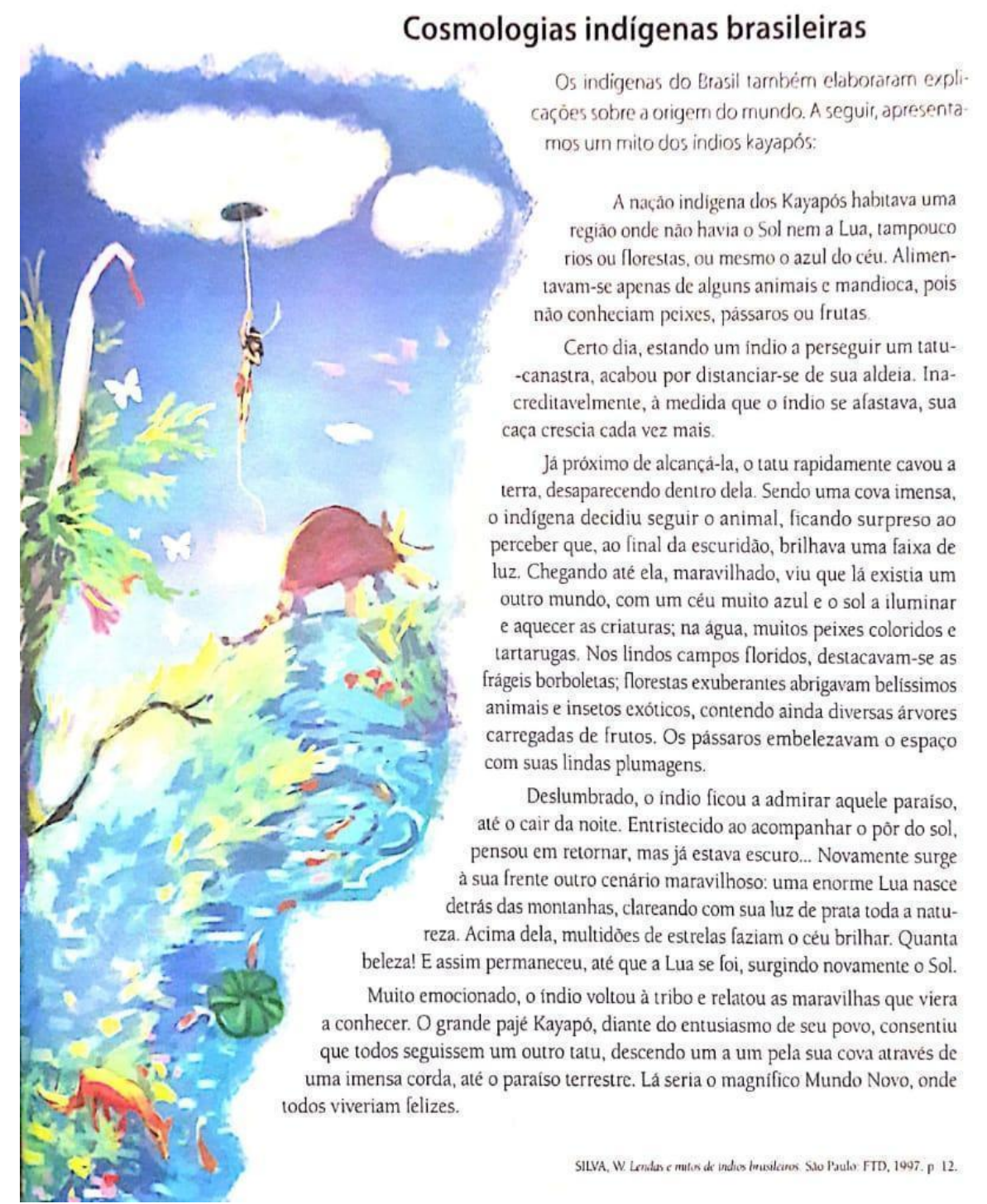

Figura 9: Atividade sobre cosmologia indígena encontrada na coleção 08.

Fonte: Pietrocola et al. p. 21, 2016.

O que diz respeito à essa atividade no Manual do Professor, não é possível identificar uma orientação de maneira profunda e contextualizada. O que é exigido/proposto é uma orientação de pesquisa para os/as estudantes sobre diferentes concepções cosmológicas.

Ainda nesta coleção, encontramos um breve texto sobre o conhecimento chinês da Antiguidade citando como era esta compreensão acerca do fenômeno dos 
eclipses. A explicação é feita de forma sucinta com a imagem dessa concepção ao lado.

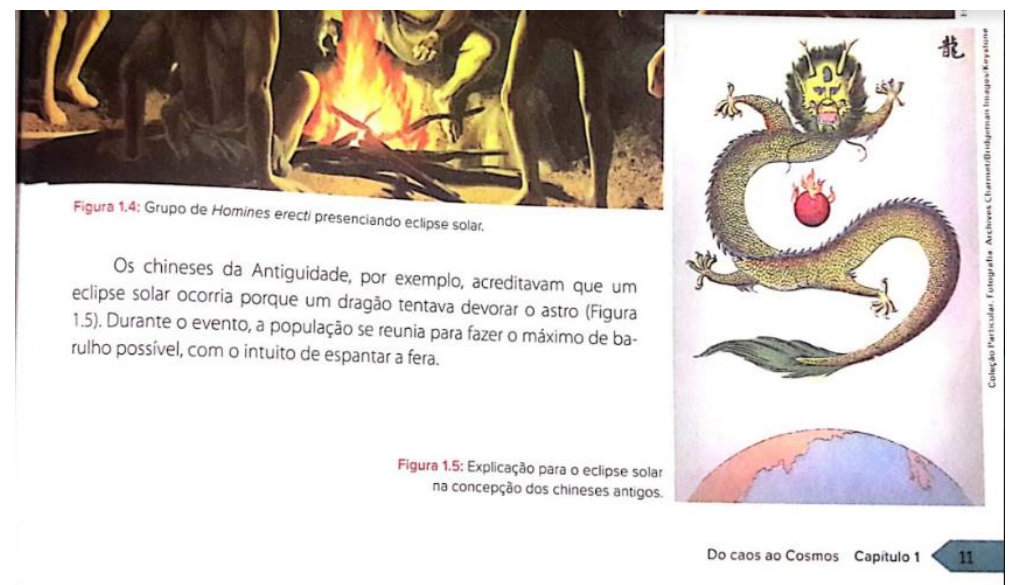

Figura 10: Representação do eclipse pelos chineses na coleção 08.

Fonte: Pietrocola et al.p.11, 2016.

Como exemplo da categoria "Comparativo", encontramos na coleção de número 02, o seguinte box sobre o mito Caiapó. No início do box, percebemos a representação do mito por meio de uma gravura e, na sequência, logo no início do texto, destacamos o seguinte trecho: Você sabe como as estrelas surgiram? Para essa pergunta, podemos elaborar e encontrar diferentes respostas. Uma delas, dada pela Ciência, [...]. Na sequência, o texto segue dando uma explicação do surgimento das estrelas pela concepção científica moderna. Ao final do texto, encontramos a seguinte pergunta, com relação ao que foi apresentado: "Olhando para a gravura, como você acha que eles explicaram as estrelas e o surgimento do mundo? ". O que nos parece confuso para este box é o que se espera como resposta, uma vez que os autores não deixam claro que as lógicas de pensamento de cada cultura são únicas. Desta forma, essa "nova explicação" somente com base na gravura, torna-se uma "criação de qualquer coisa", acarretando - de modo implícito - em um comparativo com a explicação para o fenômeno com base na tradição científica clássica. 


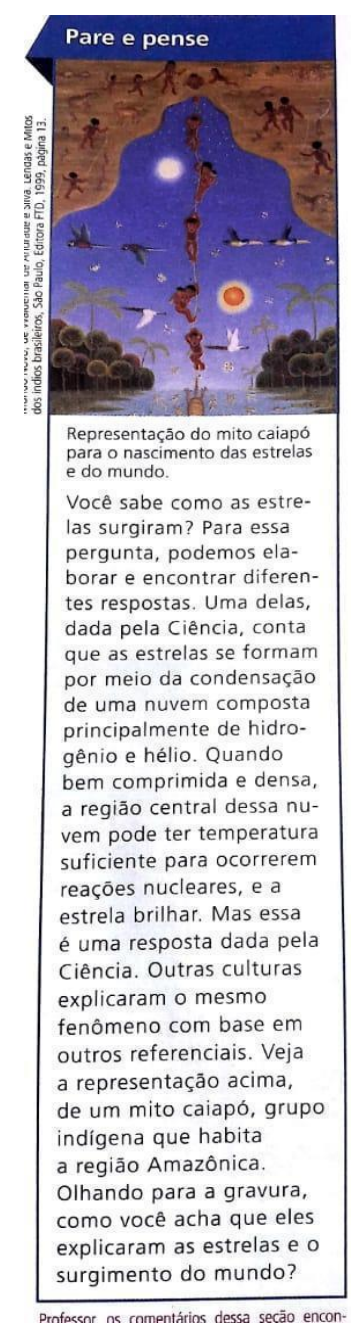

Figura 11: Representação do mito caiapó encontrado na coleção 02.

Fonte: Barreto, Xavier, p.14, 2016.

Para essa atividade, a orientação no Manual do Professor também não aprofunda a questão epistemológica dos mitos.

Com relação à última categoria, que apresenta os elementos que não conversam entre si e nem com as outras categorias, denominada "Outros", encontramos na coleção 08, no primeiro capítulo "Do caos ao cosmos", um conteúdo se inicia de forma a contextualizar como os seres humanos sempre foram intrigados por conhecer e desvendar o cosmos. Para isso, na página de abertura, temos a imagem da constelação de Escorpião, do Anzol e de Anhã, como indica a imagem abaixo. Todavia, não percebemos a presença de um texto que contextualiza essas constelações. Neste primeiro momento, elas são citadas como legenda das figuras apresentadas. 


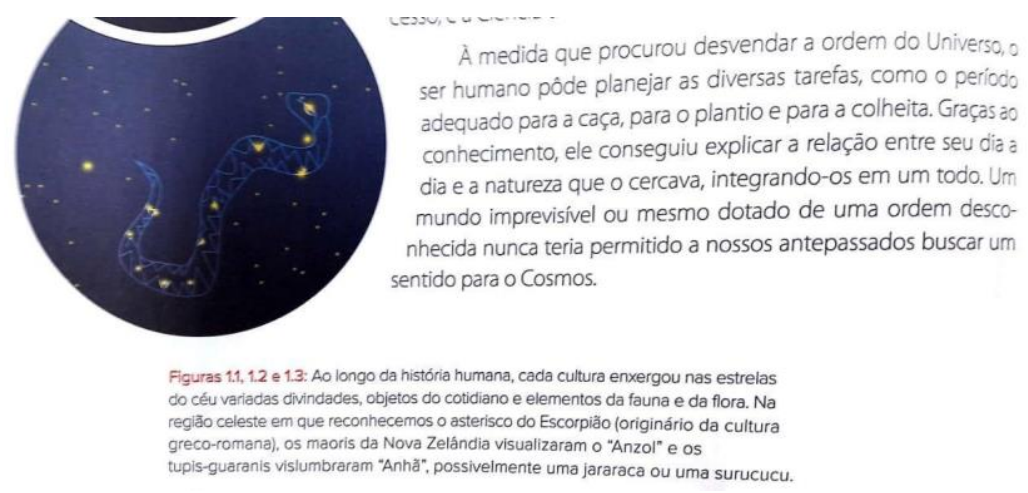

Figura 12: Exemplo de constelação indígena representada na coleção 08.

Fonte: Pietroloca et al, p.10, 2016.

Nessa mesma coleção, ao final do primeiro capítulo, encontramos na seção "ENEM", um exercício que contempla os conhecimentos indígenas. O exercício apresenta uma das constelações da etnia Guarani e, em seguida, o mesmo espaço do céu, mas agora com constelações não indígenas. O propósito do exercício acaba sendo simplesmente apresentar ambos os conhecimentos. Assim, o exercício citado encontra-se nas imagens a seguir. 


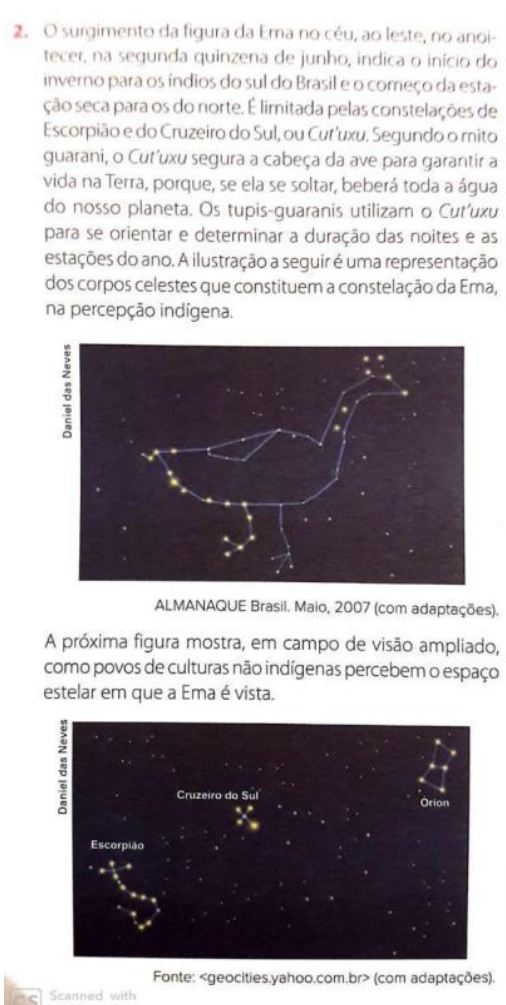

Considerando a diversidade cultural focalizada no texto e nas figuras, avalie as seguintes afirmativas.

I. A mitologia guarani relaciona a presença da Ema no firmamento às mudanças das estaçōes do ano.

II. Em culturas indígenas e não indígenas, o Cruzeiro do Sul, ou Cut'uxu, funciona como parâmetro de orienta. çäo espacial.

III. Na mitologia guarani, o Cut'uxu tem a importante função de segurar a Ema para que seja preservada a água da Terra.

IV. As Três Marias, estrelas da constelaçăo de Órion, compõem a figura da Ema.

É correto apenas o que se afirma em:
a) I.
(d) I, II e III.
b) II e III.
e) I, II e IV

cal) lid eiv.

Figura 13: Exercício do ENEM encontrado na coleção 08.

Fonte: Pietrocola et al, p. 40, 2016

A coleção 4, apresenta em um de seus livros a imagem da constelação da Ema - relacionada a cultura indígena - porém, nenhuma menção ou explicação da imagem é feita ao longo do texto. Para além disto, a legenda desta imagem (a seguir) não traz nenhuma menção a esta constelação da cultura indígena e nos traz algumas interpretações. A palavra "recriar" na legenda pode nos dar a entender que a ciência moderna simplesmente recria o céu de qualquer época com as novas tecnologias, mas esta mesma palavra pode dar a entender que a ciência atual recria porque o que vem antes (criação dos antepassados) não é válido, tendo então, a necessidade de recriar. 


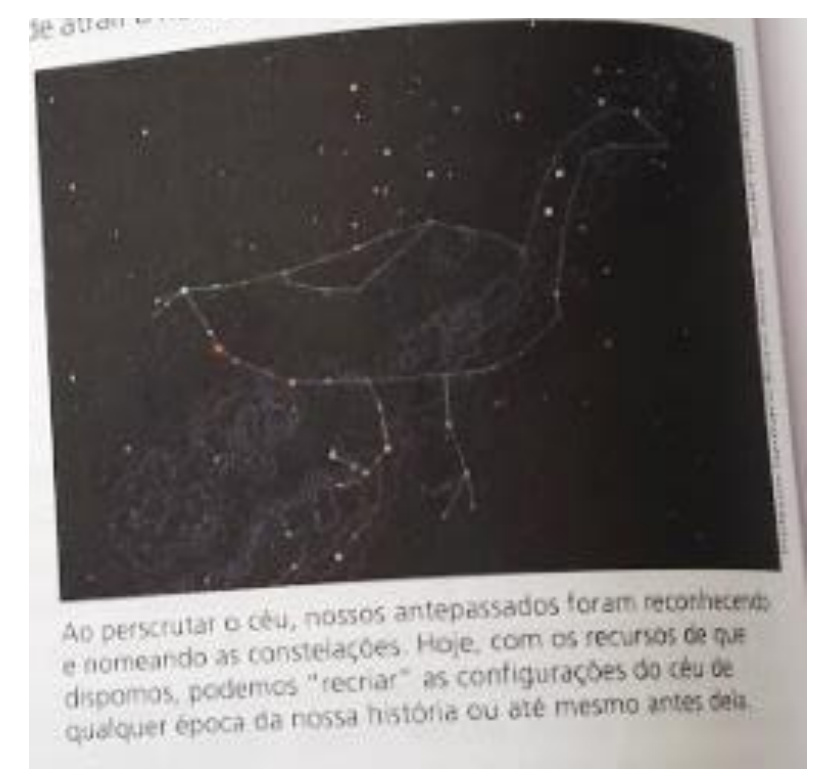

Figura 14: Constelação da Ema presente na coleção 04.

Fonte: Yamamoto; Fuke. 2016, p.236.

A legenda da imagem está transcrita a seguir.

\begin{abstract}
"Ao perscrutar o céu, nossos antepassados foram reconhecendo e nomeando as constelações. Hoje, com os recursos que dispomos, podemos "recriar" as configurações do céu de qualquer época da nossa história ou até mesmo antes dela. " (YAMAMOTO; FUKE. 2016, p.236)
\end{abstract}

\title{
3.3.2. Livros didáticos de Ciências
}

Para os livros de Ciências, que são um total de 48 livros analisados, a temática da Astronomia é mais recorrente de ser encontrada nos livros de $6^{\circ}$ e $9^{\circ}$ ano, ficando em ausência na maioria dos livros referentes aos $7^{\circ}$ s anos e na ausência total dos livros de 8ㅗ anos - nestes há uma dedicação maior aos temas ligados à Biologia.

Como nos livros de Física, antes de apresentarmos em detalhes os resultados, representamos abaixo o gráfico dos resultados das categorias referentes às coleções e livros de Ciências do PNLD 2017. Neste primeiro gráfico, representamos os resultados por coleção, ou seja, incluímos na categoria "Menos valorizados socialmente" as coleções que tivessem pelo menos um de seus livros com um viés cultural pertencente a esses grupos. 
Gráfico 4: Resultados das coleções de Ciências em cada categoria.

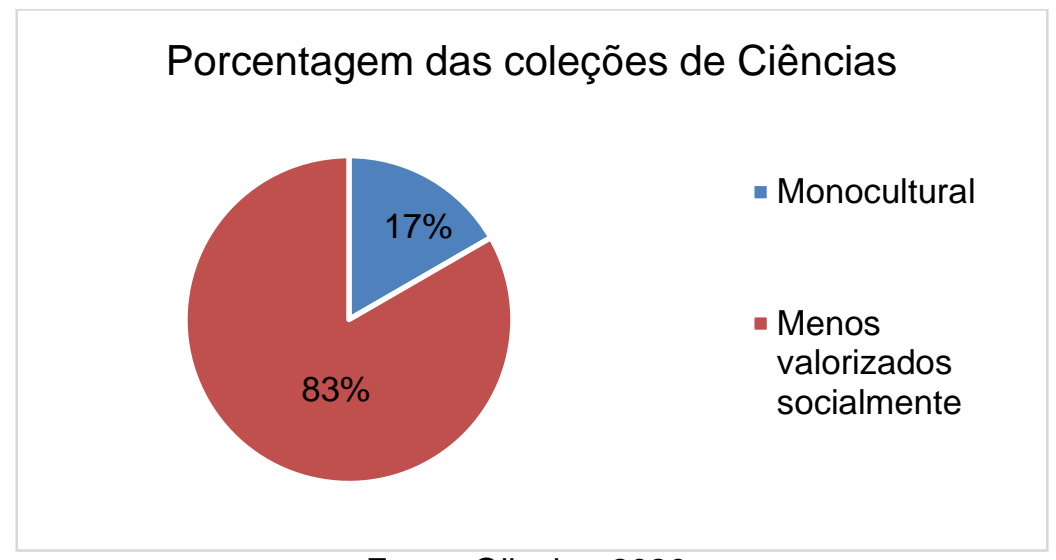

Fonte: Oliveira, 2020.

No segundo gráfico apresentamos o resultado por livro didático. É possível perceber uma diferença percentual e até uma inversão do gráfico quando focamos em cada livro analisado.

Gráfico 5: Resultados dos livros de Ciências em cada categoria.

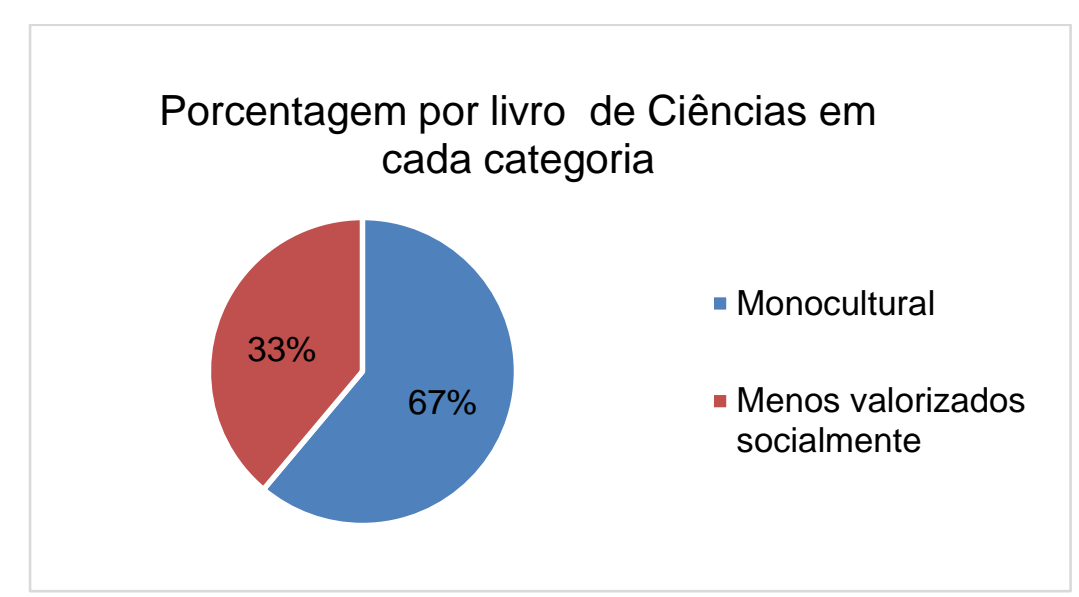

Fonte: Oliveira, 2020.

Percebemos então que a maioria das coleções apresentam ao menos um livro que contém uma perspectiva cultural nos conteúdos de astronomia. Dos $86 \%$ das coleções que se encontram na categoria de "Menos valorizados socialmente", metade delas só entra neste grupo pelo livro do $6^{\circ}$ ano.

A tabela a seguir apresenta a distribuição de cada um dos livros de $6^{\circ}, 7^{\circ}$ e $9^{\circ}$ anos em suas respectivas categorias. 
Tabela 12: Distribuição dos livros didáticos de Ciências por categoria.

\begin{tabular}{|c|c|c|c|c|c|c|}
\hline \multirow[b]{2}{*}{ Coleções } & \multicolumn{3}{|c|}{ Monocultural } & \multicolumn{3}{|c|}{$\begin{array}{l}\text { Menos valorizados } \\
\text { socialmente }\end{array}$} \\
\hline & L6 & L7 & L9 & L6 & L7 & L9 \\
\hline 1 & & & $x$ & & & \\
\hline 2 & & & & $x$ & & \\
\hline 3 & & & & $x$ & & $x$ \\
\hline 4 & & & & $x$ & & \\
\hline 5 & & & & $x$ & & $x$ \\
\hline 6 & & & & $x$ & & \\
\hline 7 & & & & $x$ & $x$ & $x$ \\
\hline 8 & $x$ & & & & & \\
\hline 9 & & & & $x$ & $x$ & \\
\hline 10 & & & & $x$ & & \\
\hline 11 & & & & $x$ & & \\
\hline 12 & & & & $x$ & & $\mathrm{x}$ \\
\hline
\end{tabular}

Fonte: Oliveira, 2020.

\section{Categoria "Monocultural"}

Encontramos dentro da amostra analisada, a presença da cultura hegemônica (europeia-ocidental) em todos os livros que abordam Astronomia. Porém, como incluímos nesta categoria os livros que falam somente desta cultura tradicional, incluem-se aqui as coleções 1 e 8.

Nestas coleções, a presença destes elementos vinculados à astronomia são dados exclusivamente pelo viés histórico em que, figuras como Aristarco de Samos, Copérnico e Galileu Galilei são encontradas facilmente.

$\mathrm{Na}$ imagem a seguir apresentamos dois exemplos de como a história da Astronomia é apresentada nos livros analisados. Percebemos que o próprio viés histórico também não é muito explorado e acabam contemplando poucas ou uma página dentro dos capítulos de Astronomia. Além destes astrônomos já citados, muitos livros abordam a importância da IAU (International Astronomical Union) e suas contribuições para o mapeamento das constelações, dos consensos de medidas astronômicas, entre outros aspectos. 


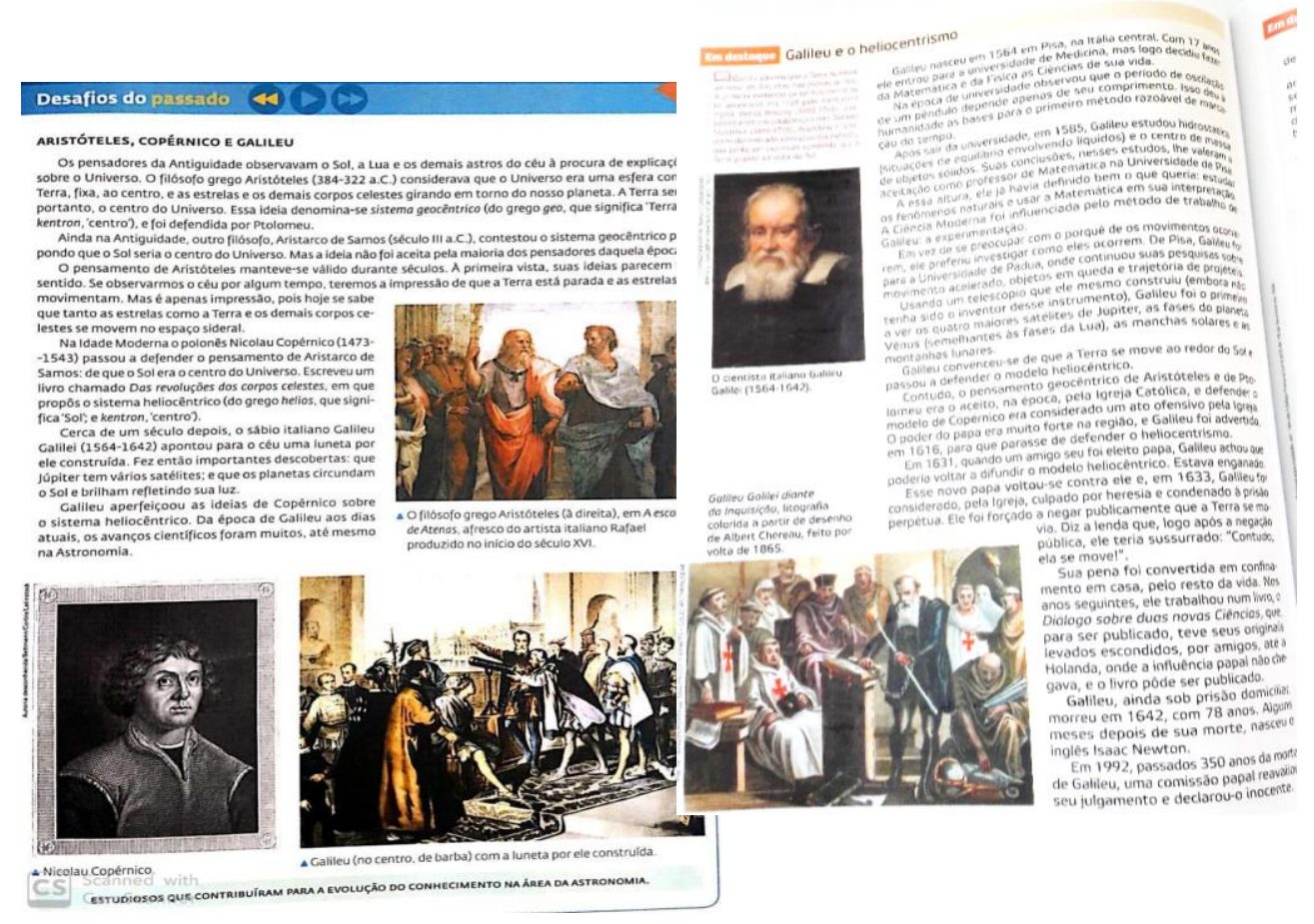

Figura 15: Introdução à temática da Astronomia no livro de 60 ano na coleção 08 e Introdução à temática da Astronomia no livro de $9^{\circ}$ ano na coleção 01 , respectivamente.

Fontes: Barros, Paulino, p. 233, 2016; Canto, E. p. 190, 2016.

Como dito anteriormente, nessa categoria entraram apenas as coleções que não apresentaram em nenhum de seus livros um viés cultural que transpasse a cultura ocidental hegemônica, mas, como ressaltado, muitos livros das coleções que apresentaram ao menos um livro na outra categoria, poderiam se encaixar aqui por serem também considerados monoculturais, de acordo com os olhares do que seria intercultural nesta pesquisa.

\section{Categoria "Menos Valorizados Socialmente"}

Para os livros de Ciências analisados na amostra, dez das doze coleções apresentam algum conhecimento relacionado à alguma outra cultura que não seja a europeia ocidental. Nestes elementos encontram-se algumas temáticas como: 
Origem do Universo, primeiros registros do céu, Sol e Lua, Constelações e contagem do tempo (calendários).

Podemos perceber novamente que, mesmo com a presença dos conhecimentos de outras culturas, que não seja a tradicional, estes livros, em grande parte, não valorizam a temática, de forma que o conteúdo seja apresentado de maneira muito pontual.

Assim, as categorias utilizadas para esta análise são as mesmas que utilizamos nos livros de Física - Narrativas, Comparativo e Outros - pois, acreditamos que estas contemplam os dados encontrados nos livros desta amostra.

A tabela a seguir, apresenta a distribuição dos livros de Ciências na categoria "Menos valorizados socialmente".

Tabela 13: Distribuição dos livros didáticos de Ciências na categoria Menos Valorizados Socialmente

\begin{tabular}{|c|c|c|c|c|c|c|c|c|c|}
\hline \multirow[b]{3}{*}{ Coleções } & \multicolumn{9}{|c|}{ Categoria "Menos Valorizados Socialmente" } \\
\hline & \multicolumn{3}{|c|}{ Narrativas } & \multicolumn{3}{|c|}{ Comparativo } & \multicolumn{3}{|c|}{ Outros } \\
\hline & L6 & L7 & L9 & L6 & L7 & L9 & L6 & L7 & L9 \\
\hline 2 & $x$ & & & & & & $\mathrm{x}$ & & \\
\hline 3 & $x$ & & $x$ & $\mathrm{x}$ & & $x$ & & & \\
\hline 4 & & & & & & & $x$ & & \\
\hline 5 & & & & & & & & & \\
\hline 6 & $\mathrm{x}$ & & & & & & $x$ & & \\
\hline 7 & $x$ & $x$ & $x$ & $\mathrm{x}$ & $x$ & & & & $x$ \\
\hline 9 & $x$ & $x$ & & & & & $x$ & & \\
\hline 10 & $\mathrm{x}$ & & & $\mathrm{x}$ & & & $x$ & & \\
\hline 11 & $x$ & & & & & & $x$ & & \\
\hline 12 & $x$ & & & & & & $x$ & & \\
\hline
\end{tabular}

Fonte: Oliveira, 2020.

Assim como nos livros de Física, nos livros de Ciências, os conhecimentos advindos de outras culturas também aparecem, em sua maioria, dentro da categoria "Narrativas". Todavia, para estes livros, percebemos que existe um leque maior de elementos de outras culturas que, ao compararmos com os livros de Física, os livros de ensino fundamental 2, tornam-se mais ricos na perspectiva cultural.

Percebemos que em alguns exemplares há uma certa constância em se apresentar ao final do capítulo dedicado à Astronomia, uma página em que se fala 
dos povos indígenas. Por vezes, apresentam parte da cultura voltado à alguma etnia específica, outras vezes apresentam contos mitológicos sobre alguma "coisa do céu"6.

Como exemplo desta primeira categoria, o livro de $6^{\circ}$ ano da coleção 3 , cita em um dos parágrafos, os primeiros registros astronômicos relacionados com as observações do céu e cita, além dos egípcios e babilônios, os assírios e os chineses, inclusive com uma imagem do antigo mapa estelar chinês. Após essa apresentação, não há nenhuma atividade que explore ou promova a importância de se valorizar os conhecimentos orientais - principalmente aqueles que provêm da cultura chinesa - e dos por quês do conteúdo desta cultura ser importante.

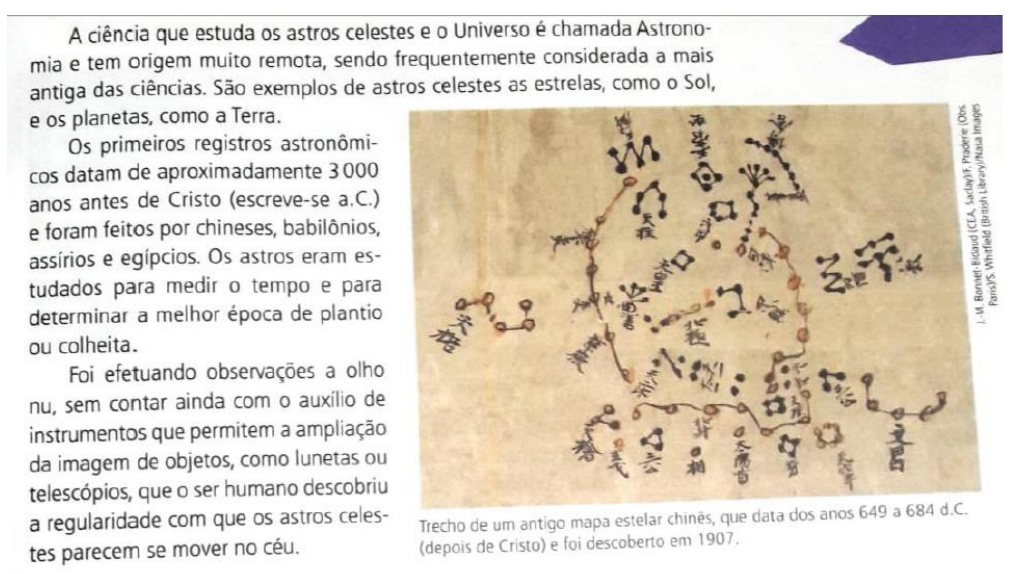

Figura 16: Texto e imagem retirados do livro de $6^{\circ}$ ano da coleção 03.

Fonte: Lopes, S. p.19, 2016.

$\mathrm{Na}$ coleção 07 , no livro do $9^{\circ}$ ano, encontramos uma página do capítulo "Universo e a Astronomia" que os autores se dedicam a apresentar a concepção de diversas culturas acerca da origem do Universo. Diferentemente dos outros, este livro apresenta um conteúdo dos lorubás - grupo de etnia africana localizada na região da Nigéria - respeitando também parte da Lei 11.645/08.

\footnotetext{
${ }^{6}$ Exemplos desta questão podem ser encontrados no Anexo 01
} 


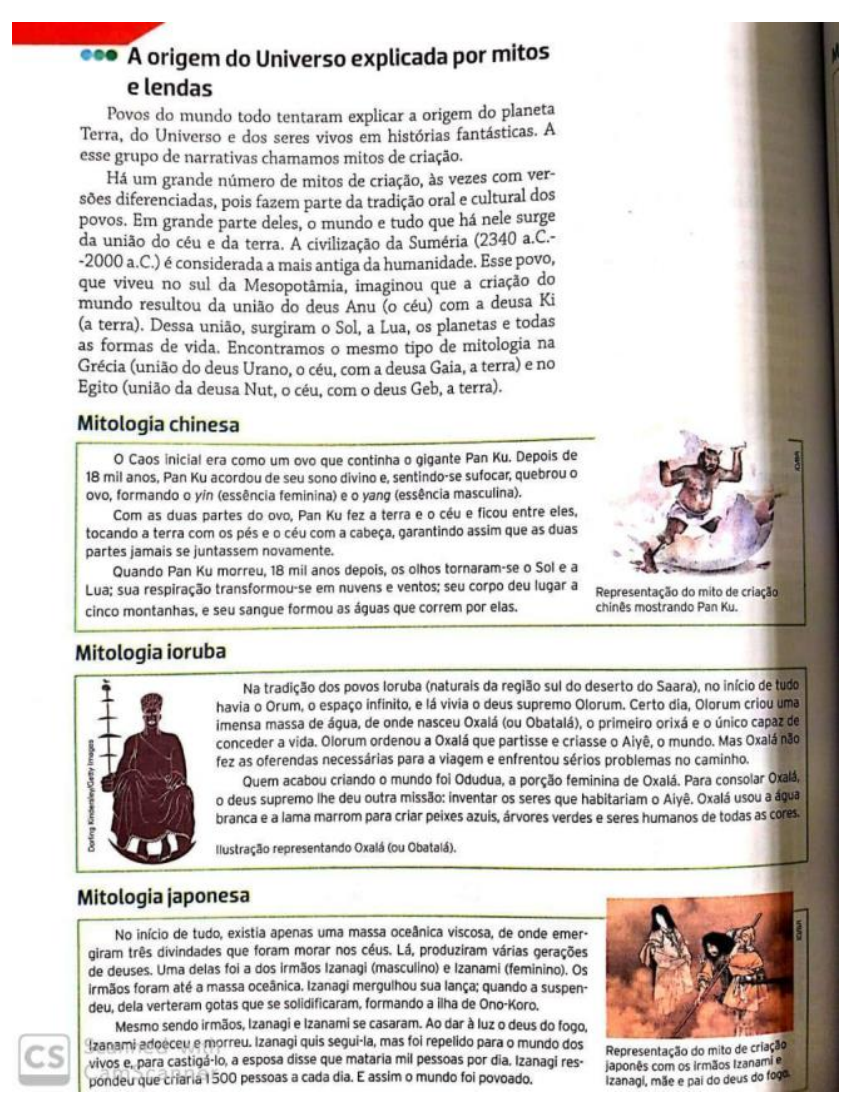

Figura 17: Livro de 9ำ ano da coleção 7.

Fonte: Edições SM. p.274, 2016.

Na coleção 10 , no livro de $6^{\circ}$ ano, numa seção chamada "Ciência e História" encontramos um pequeno texto que trata da constelação da Ema e do Homem Velho, ambas pertencentes à cultura dos povos Guarani do Brasil.

Todavia, o texto é sucinto e descritivo, não contextualizando esta temática. Como consta na imagem a seguir, a constelação que acompanha o texto é a constelação de Touro. Ou seja, por mais que os autores tragam temáticas da cultura indígena e que a constelação do Homem Velho tenha parte dela inserida na constelação de Touro, as informações não têm profundidade, tampouco ressaltam o conhecimento produzido por essa cultura. 


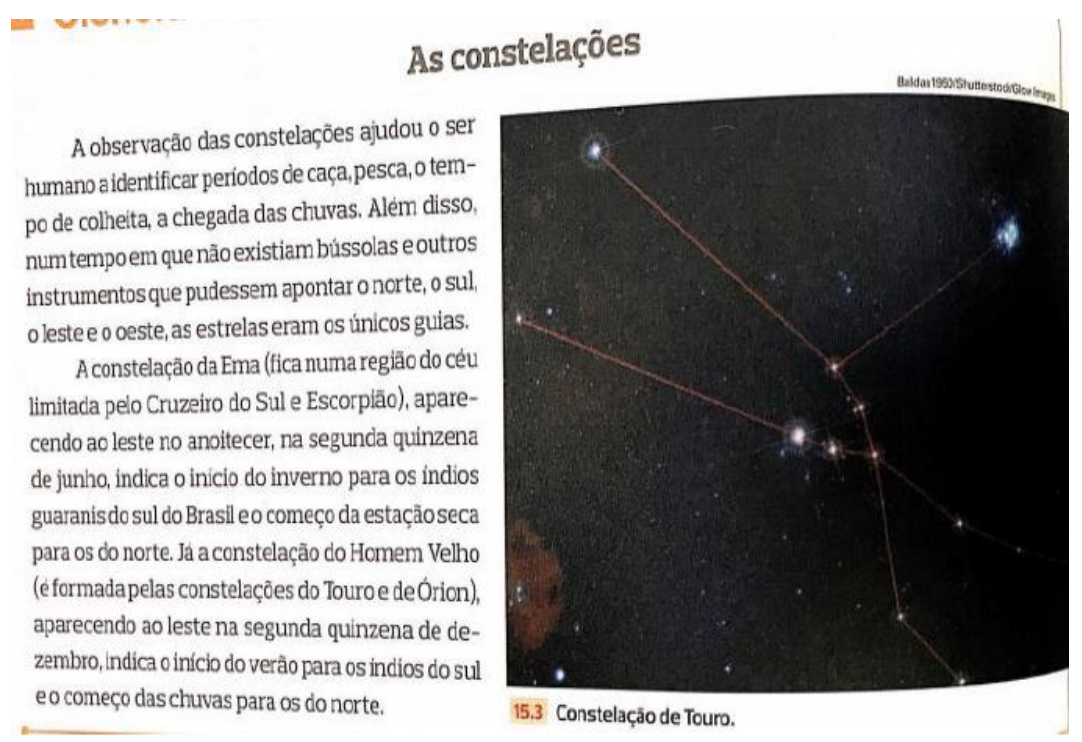

Figura 18: Texto e imagem retirados da coleção 10, no tópico "Constelações".

Fonte: Gewandsznajder, F. p.208, 2016.

Um outro exemplo desta categoria em que agrupamos as narrativas, são os textos de terceiros que aparecem nos livros. No capítulo 2 da coleção 03, por exemplo, no livro do $6^{\circ}$ ano, os autores apresentam no tópico "As estrelas: Movimento aparente" um texto de título "O papel das lendas e mitos da cultura indígena" retirado do Instituto Ciência Hoje. O texto aborda brevemente alguns aspectos dos mitos indígenas com relação ao Sol, Lua e as constelações. Com relação à imagem, logo no início, temos uma representação da criação do universo na visão dos Kaiapós. Porém, o texto discorrido não deixa claro se o conteúdo diz respeito a esta etnia ou a algum outro grupo indígena, o que pode nos dar a entender de que todos os povos indígenas compactuam das mesmas concepções acerca deste fenômeno. $O$ que não é verdade. 


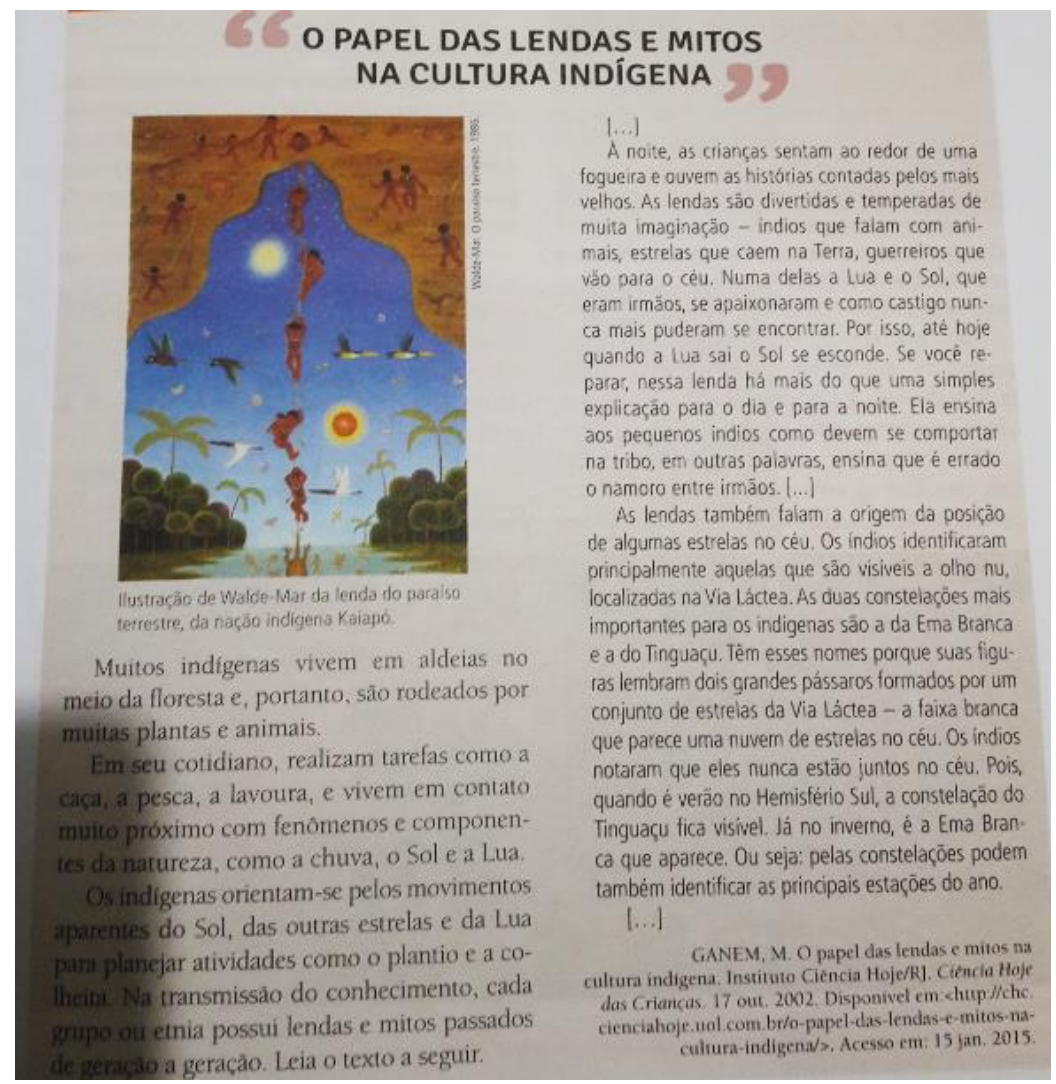

Figura 19: Texto e imagem retirados do livro de $6^{\circ}$ ano da coleção 3.

Fonte: Lopes, S. p.35, 2016.

Para a subcategoria "Comparativo", agrupamos os elementos que aparecem nos livros que, de alguma forma, trazem uma comparação entre a os conhecimentos científicos tradicionais e os que são produzidos por outras culturas. Para esta subcategoria, encontramos 6 elementos que estão contidos em 4 coleções (3,5,7 e 10). Como exemplo do que foi encontrado e selecionado para compor este grupo, temos, a seguir, um box da coleção 05 que solicita uma discussão com os/as estudantes acerca da temporalidade entre as teorias científicas e os mitos. Como exemplo destes mitos, os autores apresentam um texto sobre a mitologia grega. 


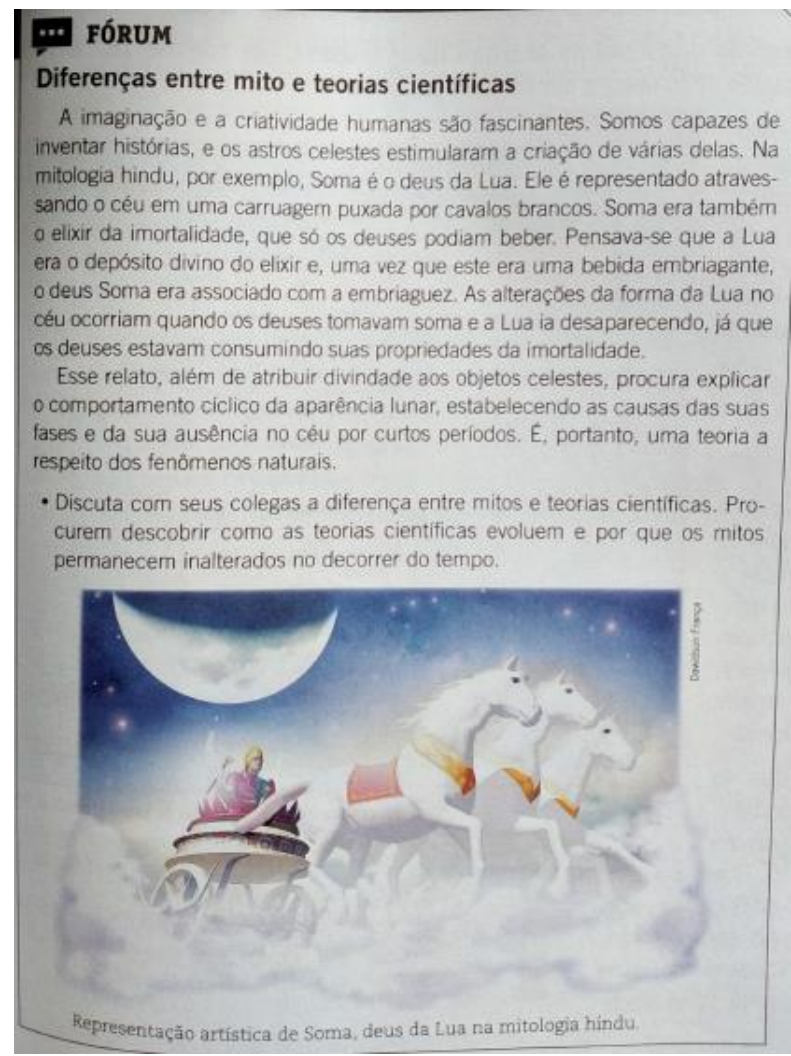

Figura 20: Box encontrado na coleção 05 comparando teorias científicas e mitos.

Fonte: Trivellato et al. p. 203, 2015.

Um outro exemplo do que pode ser encontrado nestes materiais, são atividades de pesquisa que envolvem a comparação entre os conhecimentos desenvolvidos por diferentes culturas. A atividade exemplificada a seguir, aparece dentro de um box denominado "Integração" que tem como foco, a relação entre a construção de calendários e os elementos celestes.

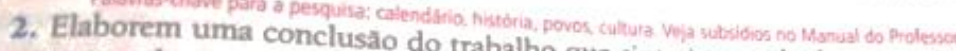

pensando nas seguintes questōes: Af que sintetize a vida de uma cultura e seu calendário, sobrevivencia e desenvolvimento de Afinal, a mediçăo do tempo é fruto das necessidades de de "marca" da cultura de uma nacào? Sug cultura? Vocé acha que o calendàrio é uma espécie culturas propostas abaixo paraçà ? Sugerimos que cada grupo de estudantes escolha duas vuras e outras imagens relacionada ao tema.

Culturas:

Egipcia - Babilonica - Chinesa - Maia - Judaica - Muçulmana - Romana - Tupi-guarani

Figura 21: Atividade retirada do livro de $9^{\circ}$ ano da coleção 03.

Fonte: Lopes, S. p.121, 2016. 
Sobre os conhecimentos indígenas presentes nesta subcategoria, o exemplo a seguir foi retirado do livro de $6^{\circ}$ ano da coleção 07 . Neste livro é encontrada uma seção "Lendo Ciências" que tem por título "Conhecimentos Astronômicos Indígenas". Antes da leitura do texto, os autores sugerem que haja uma discussão sobre as semelhanças e diferenças entre conhecimentos tradicionais e conhecimentos científicos.

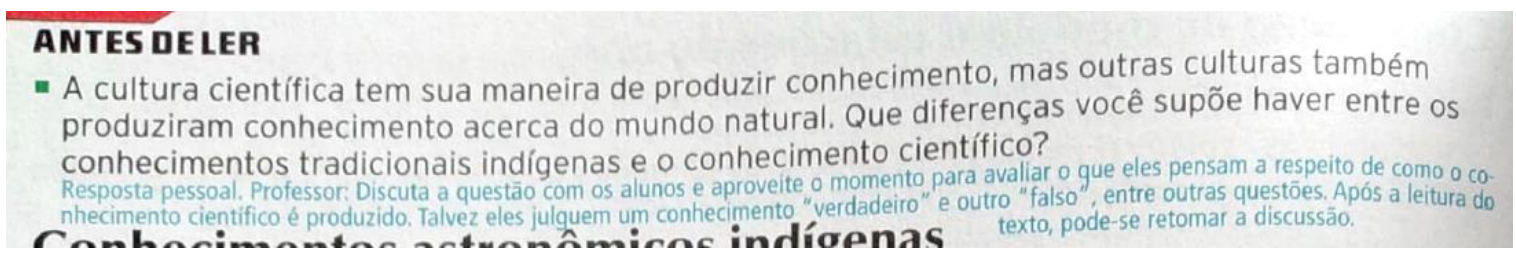

Figura 22: Questão retirada do livro de $6^{\circ}$ ano da coleção 07.

Fonte: Edições SM , p. 250, 2015.

O texto (Anexo 02) apresentado posterior à esta questão, é retirado da revista Ciência e Cultura e, apesar de tratar os conhecimentos indígenas como empíricos, os coloca numa posição de fábula (palavra retirada do próprio texto). Esse viés comparativo se torna evidente ao longo do texto, mas também, é encontrado nas questões que são colocadas ao final dele.

\section{De olho no texto}

1. Que conhecimentos astronômicos indígenas são citados no texto? Eles estão em concordância com outros conhecimentos científicos?

2. Que hipótese o autor levanta para o fato de os indígenas terem explicações para certos fenômenos naturais mesmo antes da ciência moderna?

o centrecinentassobrena iéacáo entre as fases da tua e o ciclo das matés. Os ind quars os indigenas controem seus conhecimentos.

das constelasoes com eventos meteorológicos que acontecem ao longo do ano, corm periodos de chuva e estiagem, de calor ou do frio. A relaça entices

Figura 23: Questões retiradas do livro de $6^{\circ}$ ano da coleção 07.

Fonte: Edições SM, p. 250, 2015.

Para a subcategoria "Outros", que são elementos pontuais e diferentes entre si, que trazem a diversidade cultural e conhecimentos das culturas menos valorizadas que podem aparecer tanto em forma de questão, box, etc, e que são relevantes de serem apresentados. Além dos exemplos abaixo, outros também podem ser encontrados no anexo 03. 
Como exemplo desta subcategoria, encontramos na coleção 2, no livro do 6 o ano, uma seção "Constelações Indígenas Brasileiras" em que há um texto sobre as diversas etnias dos indígenas brasileiros e imagens de suas representações do céu, como do povo Guarani, Tembé e Tupinambá. Ainda dentro desta seção, há um box denominado "Para Refletir" que tem por intenção trazer a importância da diversidade cultural do Brasil à tona, questionando qual a importância de reconhecer e respeitar essa diversidade do país.

Sabemos que nem tudo o que consta no livro é de fato executado e guiado pelo professor. Todavia, os autores apresentam, mesmo que de forma sucinta, a intenção de trabalhar esse tipo de debate. Existe também uma parte desta atividade no manual do professor (Anexo 04) onde os autores apresentam um texto de Germano Afonso que aborda a importância de se reconhecer o conhecimento produzidos pelos indígenas do Brasil.

\section{Para refletir}

A diversidade cultural

0 Brasil é um país formado por grande variedade de povos, como os indígenas, os quilombolas, os ribeirinhos, entre outros. Cada um desses povos tem manifestações culturais próprias, com suas danças, crenças, vestuários, artesanatos, artes. A toda essa variedade de manifestações culturais damos o nome de diversidade cultural.

- Converse com os colegas: Por que é importante reconhecer e respeitar a diversidade cultural dos povos? Que manifestações culturais existem na região em que vocês vivem?

Figura 24: Box encontrado na coleção 02.

Fonte: Edições SM, 6aa, p.17, 2015.

Um outro exemplo para esta subcategoria, está presente na coleção 09, em livro de $6^{\circ}$ ano. Este livro apresenta duas páginas (a seguir) com diversos box na seção "Fique por dentro" abordando exclusivamente a "Astronomia Indígena", trazendo a constelação do homem velho e da Ema, por exemplo. O interessante é que os autores trazem a importância dos trabalhos de Claude d'Abbeville e como os povos indígenas observam o céu para suas organizações cotidianas. 


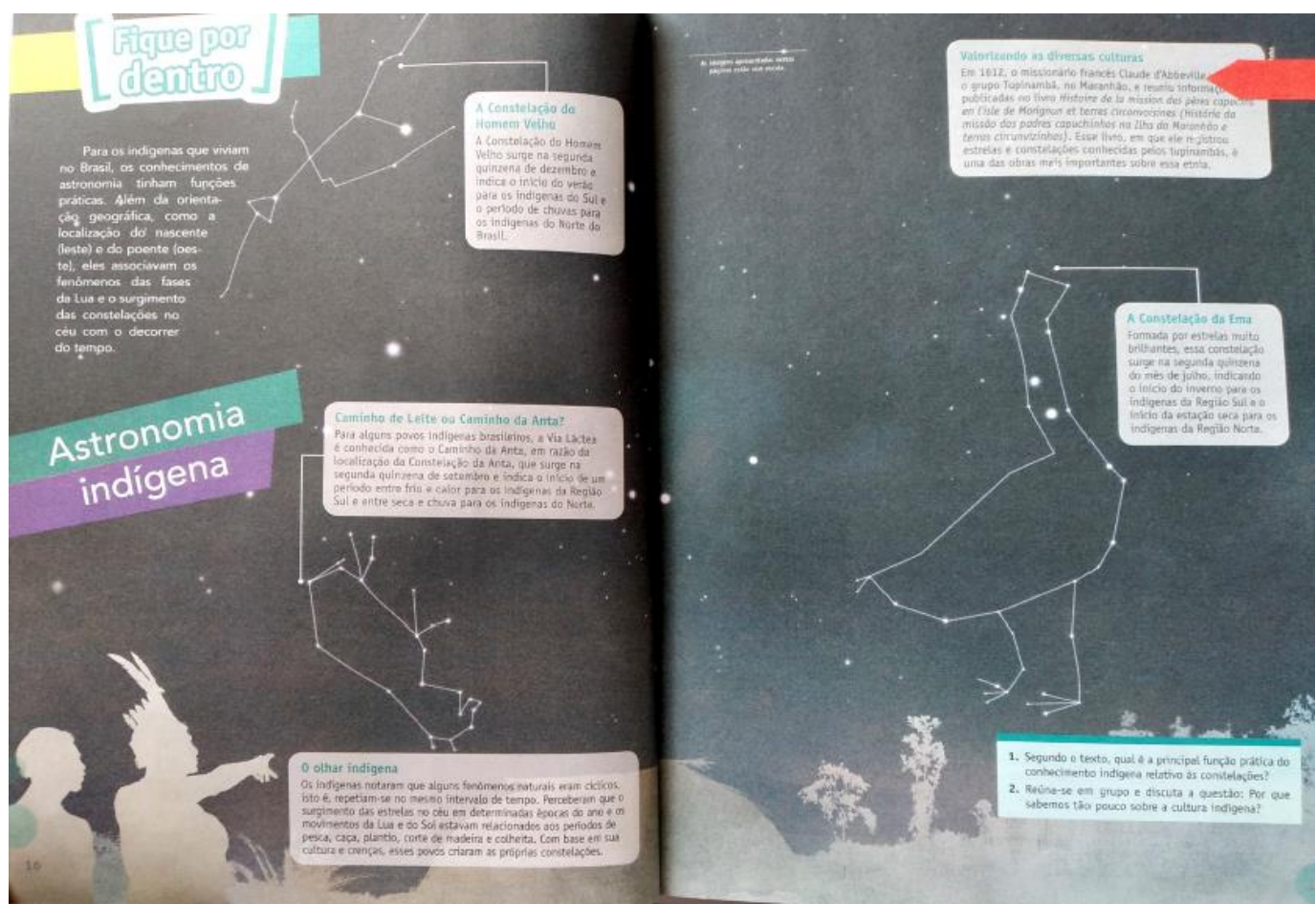

Figura 25: Páginas sobre astronomia indígena presente na coleção 09.

Fonte: Editora do Brasil, p.16-17, 2015.

Ao final desta seção, encontramos duas questões pertinentes por questionarem a escassez dos conhecimentos tradicionais e que, apesar de terem respostas que orientam o professor para este tipo de discussão, no Manual não encontramos nenhuma outra orientação.

1. Segundo o texto, qual é a principal função prática do conhecimento indigena relativo às constelações?

2. Reúna-se em grupo e discuta a questão: Por que sabemos tão pouco sobre a cultura indigena?

1. Esses conhecimentos eram utilizados principalmente para marcar o tempo. $\mathrm{O}$ aparecimento das constelaçōes no céu indica o início dos periodos favoráveis às atividades de caça, pesca, plantio e colheita.

2. Pode ser mencionado o fato de os indigenas não terem o hábito de registrar seus costumes, eles sảo passados de geraçâa a geraçâo, principalmente de forma oral. Outro ponto relevante é a quantidade reduzida de pesquisas e estudos relacionados às culturas dos povos indigenas e a baixa divulgação desse tipo de material. É importante notar que a pouca divulgação está relacionada ao preconceito que ainda há em relaçăo aos povos da floresta, no fato de sua cultura ser, erroneamente, considerada inferior à cultura trazida pelos colonizadores.

Figura 26: Questões e suas respectivas respostas referentes à coleção 09 em livro do $6^{\circ}$ ano.

Fonte: Editora do Brasil, p. 17, 2015. 
Algumas sugestões de pesquisa também foram encontradas. Porém, elas se diferem em seus contextos dentro do livro. A primeira delas, encontrada na coleção 02, aparece como um box que indica uma atividade sobre as diferentes concepções de origem do Universo. A segunda atividade de pesquisa é encontrada na coleção 12 e faz parte de uma seção "Bagagem Cultural" (Anexo 01). Nesta seção, os autores trazem diversos elementos sobre as constelações indígenas e promovem esta atividade ao final da seção.

\author{
rotering \\ Pesquise em livros, \\ revistas ou na internet \\ outros mitos sobre a \\ origem do Universo. \\ Caso conheça alguém \\ que saiba algum outro \\ mito, peça a essa pessoa \\ que $o$ conte a você. Em \\ seguida, descreva o mito \\ no caderno e ilustre-o \\ com imagens e desenhos.
}

Lua e as estrelas. Com a orientaçào do professor. pesquise outras lendas ou mitos dos
povos tupi-guarani, bororo e caiapó. Selecione três delas e registre-as
resumidamente no caderno.

Figura 27: Atividade encontrada no livro de 6ํano da coleção 02 e Atividade encontrada no livro de $6^{\circ}$ ano da coleção 12 , respectivamente.

Fonte: Edições SM, p. 21, 2015 ; Pereira et al, p. 255, 2015.

A coleção 10 apresenta essas culturas menos visibilizadas também em sua seção de exercícios quando questiona a importância das constelações na vida de diferentes povos. A questão encontra-se a seguir, junto da resposta que guia o/a professor (a).

\section{Trabalhando as ideias do capítulo}

1. Agrupar as estrelas em constelações facilita a finição de estações do ano e a construção de caidentificação delas e também a navegação, a de- c lendários.

diversos novos?

Figura 28: Atividade encontrada no livro de 6º ano da coleção 10.

Fonte: Gewandsznajder, F. p.214; 332, 2016. 


\subsection{Considerações acerca das análises}

Essa análise nos mostra que estes livros escolares considerados na amostra tanto os de Física quanto os de Ciências - ainda não trazem à tona as perspectivas multiculturais críticas, mesmo com leis e decretos que obrigam a presença destes conteúdos no âmbito escolar. O conteúdo apresentado no livro didático ainda retrata uma ciência produzida por pessoas privilegiadas, sem questionar os interesses políticos, econômicos e ideológicos e desvinculado dos contextos socioculturais e históricos (NETO; FRACALANZA, 2003), impactando diretamente naquilo que se é explorado nas salas de aula.

Percebemos também que, na maioria dos livros didáticos de Física e Ciências, encontramos uma abordagem histórica de forma problemática, pois é composta exclusivamente por datas, de modo factual e construída por grandes gênios - em geral, homens, brancos e europeus. Essa exposição da história da ciência acarreta numa desvalorização de outras culturas e um desentendimento profundo de como a ciência é construída, provocando idealizações exageradas acerca de seu desenvolvimento (MARTINS, 1990)

É possível perceber que os conteúdos das culturas menos visibilizadas se concentram mais nos livros de Ciências. Uma possível razão para ficar de fora da maior parte dos materiais do Ensino Médio é a questão do próprio vestibular, que não explora em suas provas essa temática dentro das Ciências da Natureza.

Percebemos que, tanto nos livros de Física, quanto os de Ciências, apresentam uma perspectiva multicultural que se encaixa nas dimensões assimilacionista e diferencialista (CANDAU, 2013). Na primeira, busca-se uma integração dos grupos discriminados socialmente à cultura hegemônica, porém, sem que se coloque em questão a dinâmica social e o caráter homogeneizador da sociedade.

\footnotetext{
"Essa posição defende o projeto de afirmar uma "cultura comum", a cultura hegemônica, e, em nome dele, deslegitima dialetos, saberes, línguas, crenças, valores "diferentes", pertencentes aos grupos subordinados, considerados inferiores, explícita ou implicitamente. " (CANDAU, 2013)
}

Na perspectiva diferencialista, há o reconhecimento das diversas culturas com suas respectivas características, mas não há diálogo, postura crítica e reconhecimento acerca das desigualdades e dos respectivos papéis sociais. Como ressalta Candau (2013), cria-se apartheids socioculturais. 
Nos livros, percebemos que aqueles que apresentam, de alguma forma, uma diversidade cultural, apenas cita - quase um pretexto para se "obedecer" a Lei 11.645/08 - os conhecimentos advindos de outras culturas que não seja a hegemônica (esta sim é explorada com seus desenvolvimentos e importância), adquirindo essa última perspectiva proposta por Candau (2013).

Acreditamos que tais apresentações dos conteúdos das culturas menos visibilizadas, por serem restritas aos olhos do "dominante", priva os alunos de se conceber outras visões de mundo e refletir que sempre existem diferentes olhares para a história e construção dos diferentes conhecimentos. Apresentar a história da Astronomia somente por este lado, não confronta os diferentes pontos de vista, nem proporciona os alunos as conexões acerca das culturas e as relações de poder presentes em toda a história (MCCARTHY, 1998 apud MOREIRA, CANDAU, 2003).

No que diz respeito especificamente à representação dos povos indígenas brasileiros nos livros didáticos, escolhemos por fazermos uma consideração mais profunda, visto que, pela Lei Federal № 11.645, vigorada desde março de 2008, é obrigatório o estudo de história e cultura afro-brasileira e indígena em todas as instituições no ensino fundamental e médio e, uma vez que defendemos a proposta de uma educação multicultural intercultural, de troca de conhecimentos e diálogo entre culturas, a escola deve reconhecer essas sociedades indígenas em escala histórica, social e cultural, superando a invisibilidade que essa população adquire até o presente (BERGAMASCHI, GOMES, 2012).

Sobre o que encontramos nos livros da amostra, a maioria do conhecimento relacionado às etnias indígenas estão como "box", somente uma imagem ou indicação da existência dos mesmos. Além disso, percebemos uma visão distorcida desses povos em materiais de divulgação e, ao que tudo indica, mesmo após a Lei 11.645 entrar em vigor em 2008, quase nada mudou, pelo que podemos perceber no trabalho de Grupioni (1996).

Assim, apesar da ampliação, nos últimos anos, do número daqueles que escrevem sobre os índios e de algumas tentativas de produção de materiais de divulgação, constatamos que o conhecimento produzido não tem tido 0 impacto que poderia ter: os índios continuam sendo pouco conhecidos, e muitos estereótipos sobre eles continuam sendo veiculados. A imagem de um índio genérico, estereotipado, que vive nu na mata, mora em ocas e tabas, cultua Tupã e Jaci e que fala tupi permanece predominante, tanto na escola como nos meios de comunicação. 
Ainda que o trabalho de Grupioni (1996) tenha sido realizado mais de duas décadas atrás, percebemos grande congruência da visão indígena que é veiculado nos livros do presente. A seguir, apresentamos um trecho retirado da coleção $03 \mathrm{em}$ que essa visão apresentada pelo autor pode ser constatada.

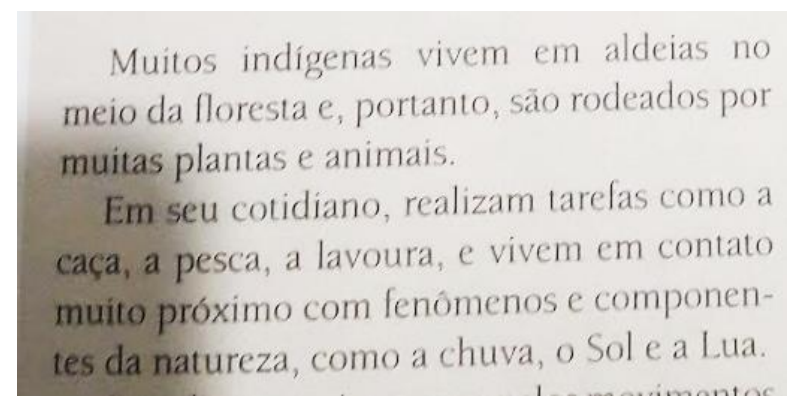

Figura 29: Texto e imagem retirados do livro de $6^{\circ}$ ano da coleção 3.

Fonte: Lopes, p.35, 2016.

Com isso, ressaltamos as quatro críticas apresentadas por Grupioni (1996) que podem ser usadas perfeitamente para algumas considerações das amostras analisadas.

A primeira delas diz respeito à estagnação dos povos indígenas e negros ao passado. Facilmente identificamos este fator quando se estuda história do Brasil em que, o indígena aparece em função do colonizador. Nos livros da amostra, isso também se apresenta por percebemos diversas vezes que são apresentados como "os antigos povos", "antigas civilizações" ou "os homens primitivos", etc.

\footnotetext{
No Hemisfério Sul, onde está o Brasil, uma das constelações mais conhecidas é o Cruzeiro do Sul. Embora a posição do Cruzeiro do Sul no céu varie conforme o dia, a hora, o local de observação e a estação do ano, o seu braço maior sempre aponta para o Sul. No Brasil, por exemplo, os antigos índios tupis-guaranis conseguiam determinar os pontos cardeais e as estaçōes do ano observando a posição do Cruzeiro do Sul ao anoitecer.
}

Figura 30: Texto retirado do livro de 6 ano da coleção 4.

Fonte: Usberco et al, p. 13, 2016.

$\mathrm{Na}$ imagem anterior, autores escrevem "os antigos índios tupis-guaranis" como se esse conhecimento fosse válido somente no passado, mas que para os "novos" índios, já se tem outros conhecimentos.

No livro de $6^{\circ}$ ano da coleção 02 , por exemplo, a introdução do tópico "Origem do Universo" é iniciado da seguinte maneira: 
"Muitas culturas antigas desenvolveram mitos para explicar a origem do Universo. Embora os mitos não tenham base científica, é preciso entender que eles eram respeitados e aceitos como verdadeiros por esses povos. Além disso, os mitos representam parte da cultura desses povos e, como tal, têm valor mesmo nos tempos atuais. " (BEZERRA, 2015, grifo nosso)

Apesar da última frase do parágrafo mencionar que estes conhecimentos devem ser valorizados culturalmente, devemos lembrar que estes conhecimentos são respeitados e aceitos por alguns povos até hoje e, por essa razão, além de terem valor cultural, devem ser valorizados.

A segunda crítica se refere à própria história que se é posta. Por ser uma história estagnada, ela não prepara os/as estudantes para conviverem atualmente numa sociedade em que essa população ainda vive - e convive/coabita. Essa interpretação, perpassa pelas gerações a ideia de história etnocêntrica, em que os indígenas e negros não são sujeito ativos, históricos e, acrescento, produzem conhecimento.

A terceira crítica se dá pela negação das culturas que provém desses povos, que sempre são apresentadas por europeus viajantes e/ou missionários. Essa problemática pode acarretar novamente em uma concepção não contemporânea dessa cultura, uma vez que, segundo essa visão etnocêntrica, o apogeu e centralidade de tudo o que é desenvolvido é inscrito na sociedade europeia.

Essa perspectiva também é encontrada nos livros, como se pode perceber nas imagens a seguir sobre a coleção 06 . Ainda que de forma não explícita, a resposta vinculada à questão atribui uma importância dos estudos da astronomia para que o processo de colonização das Américas fosse possível, deslegitimando completamente o que é produzido por qualquer outra cultura e, principalmente aos povos indígenas que aqui habitavam. 


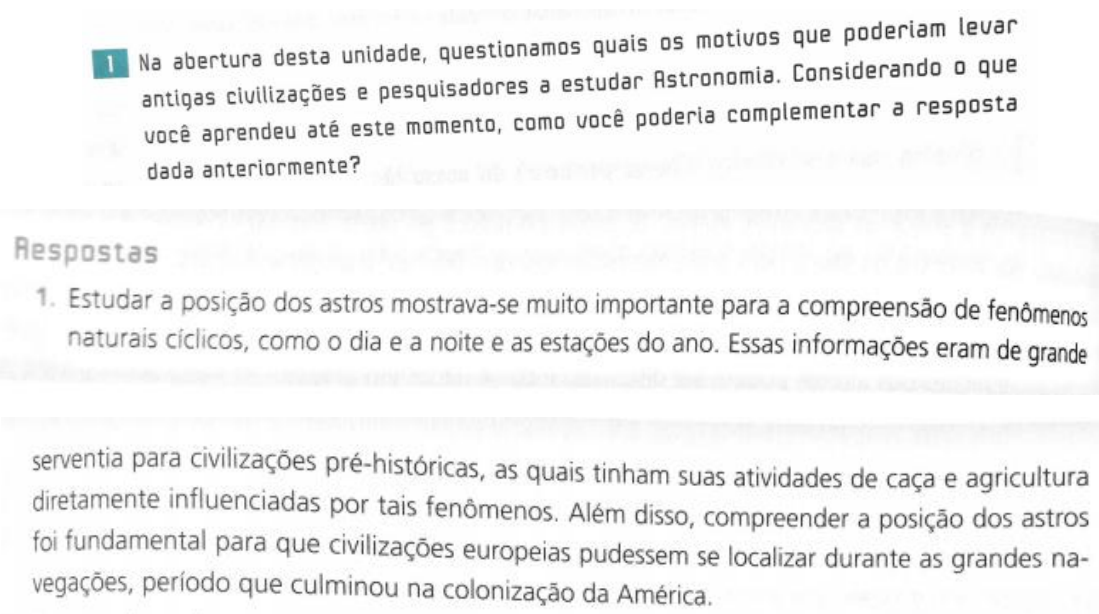

Figura 31: Pergunta e resposta encontradas na coleção 06 em livro de $6^{\circ}$ ano.

Fonte: Gowdak, Martins, p. 23;294, 2015.

Para o último tópico, Grupioni (1996) critica a generalização posta à essas culturas - dos afro-brasileiros e indígenas. Ainda que consideremos "indígenas" e "não indígenas", esses povos apresentam múltiplas características, demarcadas por sua territorialidade, vínculos com a natureza, história de lutas, hábitos e rituais que os diferenciam.

Nos livros que analisamos essa característica se faz presente, já que muitas vezes não é especificado pelos autores, a qual etnia aquele conhecimento é vinculado. Ainda que rigorosa, essa interpretação retrata o que a maioria dos livros traz sobre esses povos. Como apontam Bergamaschi e Gomes (2012):

\footnotetext{
"Essa visão deformada dos indígenas se perpetua justamente pelo fato da nossa história ser contada até hoje a partir da visão do colonizador sem dar oportunidade para que os diferentes povos apresentem a sua visão em relação a si mesmo (...)"
}

Concluímos então que os livros reconhecem a existência das múltiplas produções do conhecimento, mas não existe uma conscientização acerca da valorização desses conhecimentos produzidos e nem valorização desses povos como sujeitos. Alguns destes livros, apresentam no Manual do Professor, orientações que fomentam a pluralidade epistemológica dessas culturas menos visibilizadas, de forma a estimular os alunos a respeitar os múltiplos saberes. Porém, ainda que haja essa intenção de uma promover esse diálogo/despertar de consciência, sabemos que, 
infelizmente a presença não é sinônimo de que o conteúdo será trabalho, explorado e valorizado da forma como deve ser.

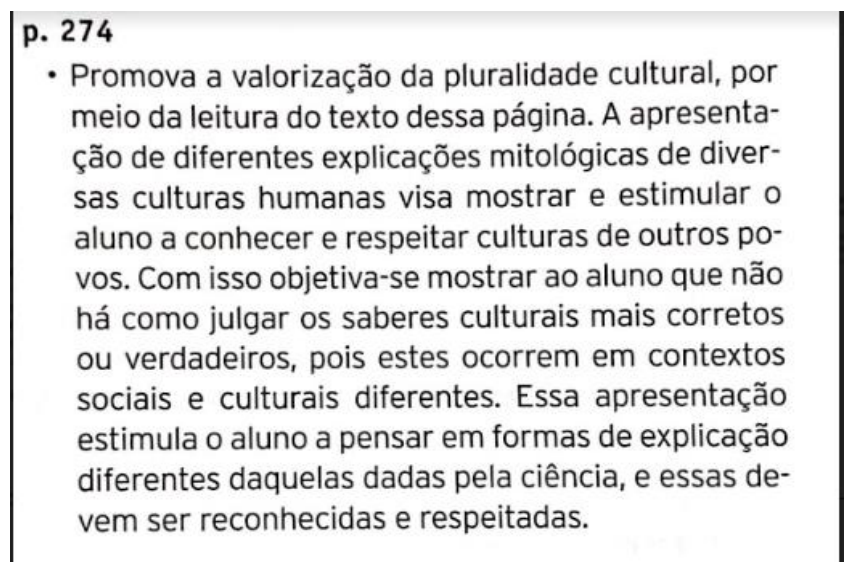

Figura 32: Livro de $9^{\circ}$ ano da coleção 7.

Fonte: Edições SM p. 396, 2016.

Segundo Telles (1987) é na infância e na juventude - ou seja, no período em que frequentamos o ambiente escolar - que aprendemos sobre as outras culturas, temos contato com a diversidade e conhecemos outros povos. Após este período, pouco se aprende acerca desta questão.

Daí vemos a importância da construção de um bom material didático. Além de ser, por vezes, o único material impresso de auxílio para o professor e para o aluno, muitas vezes é a única fonte se conhecer a imagem do Outro. (GRUPIONI, 1996)

Para finalizar, utilizamos as palavras do autor:

"Os autores destes manuais didáticos precisam rever suas fontes e as teorias que seguem, balizando seus livros em pesquisas mais contemporâneas. As editoras, por sua vez, precisam ser mais cuidadosas no controle dos materiais que publicam. E o governo federal deve incentivar avaliações sistemáticas dos livros didáticos beneficiados nos programas de compra e distribuição de material didático para todo o País. Por fim, cabe aos próprios índios - e muitos representantes indígenas já estão em condições de manter um diálogo mais efetivo com a sociedade nacional - "pacificar" e "civilizar" os não-índios." (GRUPIONI, 1996, p. 436) 


\section{ALGUMAS CONSIDERAÇÕES}

Este trabalho nos permitiu constatar que a escola brasileira passou e ainda passa por mudanças que são essenciais para que alcancemos uma educação crítica, contextualizada, plural e respeitosa para com todas as culturas e povos. Um país como o nosso, que nasce de três raças, não pode ser palco de uma educação que, desde 1500, valoriza só aquilo que provém do colonizador. Daí a importância de fomentarmos uma educação que, para além de multicultural, seja também decolonial. Segundo Boaventura (2019) "descolonizar implica descolonizar tanto o conhecimento do colonizado como o conhecimento do colonizador".

A escola, ainda com seus avanços e desenvolvimento de múltiplos avanços, continua a atender uma determinada "elite cultural" e, por essa razão, a defesa por um ensino multicultural - e decolonial - se torna relevante, pois este é capaz de respeitar as liberdades e diferenças, se concentra, para além do quesito econômico e mercadológico, mas nos valores éticos e humanos. Assim, ressaltamos também que o ambiente escolar deve colocar o debate intercultural em níveis mais profundos do que os que foram encontrados por meio das análises desta pesquisa.

A conquista da Lei 11.645/08 é um marco que deve ser lembrado em conjunto da ação dos povos indígenas e grupos afro-brasileiros - como construtores de suas próprias histórias, agendes de sua cultura e mantenedores dela, para que, desta forma, possamos encontrar um outro cenário de representação destes povos dentro das salas de aula e livros didáticos.

Percebemos nesta pesquisa, também a importância do papel do(a) professor(a) e, mais ainda, a importância de sua formação. É necessário que, neste papel de educar, sejamos críticos e questionadores das escolhas curriculares para que essas discussões possam ter espaço também na sala de aula. Segundo Freire (2017b), "é preciso ousar", de forma que possamos ir além do discurso que caracteriza a escola como um espaço exclusivo de puro ensinar e aprender - atitude esta que só mantém o status quo.

Essa realidade que contamos é o que Moreira e Candau (2003) ressaltam sobre as problemáticas das relações que envolvem a escola e as culturas e da dificuldade desta instituição em lidar com a pluralidade e a diferença. Pois, a escola, ainda que reconheça a nossa sociedade como multicultural, facilmente tenta padronizar os conteúdos e os sujeitos que a frequentam. É desta tentativa de padronização que 
surge a importância do currículo multicultural que converse com a proposta intercultural de Candau (2013), que vá além de se ensinar respeito e tolerância, mas que penetre numa reflexão mais profunda de questões que, socialmente, se tornam negligenciadas quando levadas à escola - gênero, etnia, raça. Contudo, sua falta na escola é o que nos torna mais intolerantes e frios com as diferenças presentes em nosso mundo.

Antes de avaliarmos o contexto das pesquisas, procuramos evidenciar que, para além de valorizar aquilo que aparece como possibilidade de visões de mundo e produção cultural, nesta pesquisa, procuramos pontuar a importância do Sul em suas contribuições epistêmicas e reconhecer a emergência de retirar esse povo/cultura/conhecimento da posição "de baixo". Esse olhar nos traz uma reflexão mais "severa" para que busquemos as práticas multiculturais que não sejam rasas ou que se assemelham às perspectivas assimilacionistas e diferencialistas.

A inserção da temática multicultural nas pesquisas de ensino de Física e Ciências ainda é atual e vem buscando ganhar espaço por meio de propostas e críticas acerca dos currículos, como pudermos perceber pela revisão bibliográfica realizada. Essa revisão bibliográfica nos mostra propostas que estão fazendo este movimento de valorizar a descentralização do pensamento ocidental dentro dos estudos de astronomia e, ainda que não saibamos, muitas vezes os detalhes destes trabalhos, percebemos que há uma busca para tal. Uma outra questão sobre a revisão bibliográfica que vale a reflexão, é pensarmos se existe um certo preconceito em se publicar trabalhos desta natureza em congressos/periódicos que envolvem as ciências naturais. O que queremos questionar aqui é se o número de publicações é condizente com o número de pesquisas sendo realizadas em nosso país. Há trabalhos que envolvem a interculturalidade nas ciências da natureza que não são publicados por não pertencerem ao clássico?

Por essas razões, é de grande valia que reconheçamos estes trabalhos publicados, mas que também haja criticidade ao falarmos sobre a temática para que evitemos discursos comuns e periféricos do tema, buscando valorizar o que de mais importante esse assunto nos traz, que é dar voz àqueles que não têm, reconhecimento de suas epistemologias e praticar uma democracia no ambiente escolar de forma que haja um respeito das diferenças.

Sobre os livros didáticos, apesar dos conhecimentos multiculturais serem reconhecidos pelas leis vigentes e estarem presentes nos currículos atuais de 
educação, pela análise, percebemos que esta realidade ainda se encontra distante das salas de aula do Brasil. Dos resultados que encontramos, pudemos perceber que muitos livros apresentam temas multiculturais de forma muito periférica, tornando-se por vezes, difícil realizar uma análise mais profunda. O que poderíamos concluir aqui é que, em tese, nenhum deles pode ser considerado como intercultural, como proposto por Candau (2013).

O que podemos dizer é, dentre as perspectivas apresentadas pela autora, os livros selecionados para a análise (Física e Ciências) se encaixam tanto numa perspectiva assimilacionista - que não coloca as questões de poder/colonialidade epistemológica em jogo e tenta "enturmar" os que estão de fora ${ }^{7}$ - quanto a característica diferencialista, que mantém esses conhecimentos longe e sem abertura para um possível diálogo.

Assim, é importante salientar que, por mais que o livro apresente conteúdos sobre os conhecimentos produzidos por diversas culturas, ele em si, não pode ser classificado como multicultural dentro da perspectiva do multiculturalismo crítico proposto por Candau (2013). Essa dimensão do multiculturalismo exige que haja uma valorização das identidades culturais que estão em contínuo processo de construção e reconstrução. Ademais, salienta que é indispensável que essa valorização se mostre por meio da consciência da existência das questões de poder, hierarquização e preconceitos de determinados grupos. Ou seja, tratar de perspectivas culturais nos livros, exige muito mais do que somente expor o conhecimento produzido de uma dada cultura.

Dentro da perspectiva do conhecimento indígena encontrado nas amostras, percebemos que, por mais que alguns livros apresentem elementos desta cultura dentro das concepções científicas, a maioria de seus conteúdos está veiculada a uma imagem de "crendice" ou "antepassado" com relação ao conhecimento produzido por esta cultura. Para além do demonstrar uma colonialização do saber ainda

\footnotetext{
7 Termo utilizado por Freire (2015) em seu livro "Pedagogia do Oprimido" quando trata da relação opressor-oprimido e da educação como instrumento de opressão. "[...] Como marginalizados, "seres fora de" ou "à margem de", a solução para eles estaria que fossem "integrados", "incorporados" à sociedade sadia de onde um dia "partiram", renunciando, como trânsfugas, a vida feliz. Sua solução estaria em deixarem a condição de ser "seres fora de" e assumirem a de "seres dentro de". Na verdade, porém, os chamados marginalizados, que são os oprimidos, jamais estiveram fora de. [...] Sua solução, pois, não está em "integrar-se", [...] a esta estrutura que os oprime, mas em transformá-la para que possam fazer-se "seres para si" ".
} 
percebemos os livros carregados de estereótipos com relação à esses povos, cujos traços fundamentais são de relação com a natureza e de uma cultura ultrapassada.

Com isso, faz-se urgente a viabilização dos diálogos culturais nas escolas, pois a integração de diferentes grupos que apresentam uma gama de saberes e práticas, evita que a escola reproduza os mesmos conhecimentos clássicos da cultura hegemônica. Com o multiculturalismo fora da escola, distanciamos ainda mais a formação de educandos para compreender e agir democraticamente para e com o mundo.

Contudo, assim como acreditamos que todas as culturas possam ser mutáveis de forma que reconstruímos nossas visões e intermediações com o mundo, acreditamos que o estudo da Astronomia cultural possa ser um meio propulsor para, possivelmente, abrir espaço para novas discussões acerca de um ensino humanístico na área das ciências da natureza.

Nossa pesquisa é um pequeno caminho que foi trilhado de forma a mapear os possíveis desafios e potencialidades deste tema, acreditando que esta possa auxiliar na construção de outras pesquisas futuras que, assim como nós, buscamos uma educação mais libertadora e que ultrapasse as barreiras. 


\section{REFERÊNCIAS BIBLIOGRÁFICAS}

ALBUQUERQUE, V. et al. Astronomia e Cultura nas pesquisas em Ensino de Ciências na última década. Em: Atas do I Encontro Nacional de Educação em Astronomia SNEA, Rio de Janeiro, 2011.

ALBUQUERQUE, V.; LEITE, C. Dialogar sobre ciência no Ensino Médio: A importância do (re) olhar constante a esse desafio. Em: ATAS DO XII Encontro de Pesquisa em Ensino de Física - XIIEPEF, São Paulo, 2010.

ALTHUSSER, L. Ideologias e aparelhos ideológicos de Estado. Lisboa, Presença. (s.d)

APPLE, M. Repensando Ideologia e Currículo. In: MOREIRA, A.F. SILVA, T.T. (Orgs.) Currículo, Cultura e Sociedade. São Paulo: Cortez. 2013. p. 39-57.

. Ideologia e Currículo. 3.ed. Porto Alegre: Artmed, 2006.

Educação e Poder. Porto Alegre: Artes Médicas, 1989a.

. Currículo e Poder. Educação e Realidade, v.14, n.2, 1989b, p. 46-57.

ARROYO, M. G. Currículo, território em disputa. 5.ed. Petrópolis, RJ: Vozes, 2013.

BARBOSA, P.F. Curt Nimuendaju, o conhecimento do céu Ticuna/Maguta e a observação do céu. In: I SIMPÓSIO NACIONAL DE EDUCAÇÃO EM ASTRONOMIA. Rio de Janeiro - RJ, 2011.

BARROS, V. P.; OVIGLI, D.F.B. As diferentes culturas na educação em Astronomia e seus significados em sala de aula. Revista Latino-Americana de Educação em Astronomia, n.18, 2014, p.103-118.

BITTENCOURT, C. Livro Didático e conhecimento escolar: Uma história do saber escolar. Tese de Doutorado - Universidade de São Paulo. Faculdade de Educação, São Paulo, 1993.

BITTENCOURT, C. Livros didáticos entre textos e imagens. In: BITTENCOURT, C. (Org.). $O$ saber histórico na sala de aula. 8 ed. São Paulo. 2003, p. 69-90.

BERGAMASCHI, M.A.; GOMES, L.B.A. A temática indígena na escola: ensaios de educação intercultural. Currículo sem fronteiras. v.12, n.1, 2012, p.53-69.

BOGDAN, R.; BIKLEN, S. K. Investigação Qualitativa em Educação: Uma introdução à Teoria e aos Métodos. Porto - Portugal: Editora: Porto Editora, 1994. 
BOURDIEU, P. A escola conservadora: as desigualdades frente à escola e à cultura. In: BOURDIEU, P. Escritos da Educação. Orgs: NOGUEIRA, M.A.; CATANI, A. 16 ed. Petrópolis, Rio de Janeiro: Vozes, 2015, p. 44-72.

BRASIL. Constituição da República Federativa do Brasil. Brasília, DF: Senado Federal: Centro Gráfico, 1988. Disponível em < http://www2.camara.leg.br/legin/fed/consti/1988/constituicao-1988-5-outubro-1988322142-publicacaooriginal-1-pl.html > Acesso em 29 jul. 2018.

. Declaração Universal dos Direitos dos Povos Indígenas. Senado

Federal. 2014. Disponível em: <http://www2.camara.leg.br/atividadelegislativa/comissoes/comissoes-permanentes/cdhm/instrumentos-internacionais-dedireitos-humanos/povosindigenas.html>. Acesso em: 04 ago. 2018.

Decreto-lei no 10.639, de 09 de janeiro de 2003. Altera as diretrizes e bases da educação nacional para incluir no currículo oficial da rede de ensino a obrigatoriedade da temática "História e Cultura Afro-brasileira" e dá outras providências. Diário Oficial da União, Brasília, DF, 10 jan. 2003. Seção 1, p. 1.

Decreto-lei no 11.645, de 10 de março de 2008. Altera as diretrizes e bases da educação nacional para incluir no currículo oficial da rede de ensino a obrigatoriedade da temática "História e Cultura Afro-brasileira e Indígena". Diário Oficial da União, Brasília, DF, 11 mar. 2008. Seção 1, p. 1.

. Ministério da Educação. Secretaria da Educação Básica. Base Nacional Comum Curricular. Brasília, DF, 2017. Disponível em <http://basenacionalcomum.mec.gov.br/> Acesso em 29 jul. 2018.

BRUXEL, G.; PEREIRA, A.P.; PAVANI, D.B. Atividade com Gnômon em uma comunidade indígena: uma reinterpretação do conhecimento científico pela cultura Guarani-Mbyá. Em: Atas do XVII Encontro de Pesquisa em Ensino de Física - EPEF, Campos do Jordão, São Paulo, 2018.

CANDAU, V. M. Multiculturalismo e Educação: desafios para a prática pedagógica. In: MOREIRA, A.F.; CANDAU, V. M. (Orgs.). Multiculturalismo: diferenças culturais e práticas pedagógicas. Petrópolis, RJ: Vozes, 2013, p.13-37.

. Cotidiano escolar e cultura(s): Encontros e desencontros. In: CANDAU, V.M. (Org.). Reinventar a Escola. Petrópolis, RJ: Vozes, 4 ed. 2000, p.61-78.

Diferenças culturais, cotidiano escolar e práticas pedagógicas.

Currículo sem fronteiras. v.11, n.2, Jul/Dez, 2011, p.240-255.

CAMPOS, M. A Arte de Sulear-se. In: Interação Museu-Comunidade pela Educação Ambiental, Manual de apoio a Curso de Extensão Universitária. 
SCHEINER, T. C. (Coord.). Rio de Janeiro: TACNET Cultural UNI-RIO, 1991, p. 5961, 79-84.

CARDOSO, W.T. Constellations and Time keeping used by Indigenous Communities in the Northwestern Amazonian Region. Journal of Astronomy in Culture. 2016, p.23 -39.

CHOPPIN, A. O historiador e o livro escolar. História da Educação. Universidade Federal de Pelotas. Pelotas, n. 11, abr. 2002, p. 5-24. Disponível em:

https://seer.ufrgs.br/index.php/asphe/article/view/30596. Acesso em 15 dez. 2019.

COMENIUS, J. A. Didática Magna. 4 ed. São Paulo: Editora WMF Martins Fontes, 2011.

FARES, É. A. et al. O universo das sociedades numa perspectiva relativa: exercícios de etnoastronomia. Revista Latino-Americana de Educação em Astronomia, n.1, 2004. p.77-85.

FÔNSECA, L.S.; GERMANO, A.S.M.; ARAÚJO, W.A. Conhecimentos indígenas no Ensino de Astronomia: Um estudo em publicações nacionais de educação em Astronomia. Em: Atas do V Simpósio Nacional de Educação em Astronomia - SNEALondrina, Paraná, 2018.

FORQUIN, J.C. O currículo entre o relativismo e o universalismo. Educação e Sociedade, vol.21, n.13, 2000.

. Saberes escolares, Imperativos didáticos e dinâmicas sociais. Teoria

e Educação. Porto Alegre, n. 5, 1992, p.28-49.

FREIRE, P. Educação como prática de liberdade. 40. ed. Rio de Janeiro/São Paulo: Paz e Terra, 2017a.

. Pedagogia do Oprimido. 59 ed. Rio de Janeiro: Paz e Terra, 2015.

. Pedagogia da Tolerância. 6.ed. Rio de Janeiro: Paz e Terra, 2018.

. Pedagogia da Esperança. 26.ed. Rio de Janeiro: Paz e Terra, 2019.

. Professora sim, tia não: cartas a quem ousa ensinar. 27.ed. Rio de Janeiro: Paz e Terra, 2017b.

GABRIEL, T. G. Escola e Cultura: Uma articulação inevitável e conflituosa. In:

CANDAU, V. M. (Org.) Reinventar a Escola. Petrópolis: RJ: Vozes, 2000, p.17-46.

GARCIA, C.S. et al. "As coisas do céu": Etnoastronomia de uma comunidade indígena como subsídio para a proposta de um material paradidático. Revista Latino-Americana de Educação em Astronomia. n. 21, 2016, p.7-30. 
GATTI JUNIOR, D. Livros didáticos, saberes disciplinares e cultura escolar: primeiras aproximações. História da Educação. ASPHE/FaE/UFPel. Pelotas, p.2950, 1997.

GIROUX, H. Escola crítica e a política cultural. São Paulo: Cortez: Autores Associados, 1992.

GOMES, N. L. Diversidade e Currículo. Organização do documento Jeanete Beauchamp, Sandra Denise Pagel, Aricélia Ribeiro do Nascimento. - Brasília: Ministério da Educação, Secretaria de Educação Básica, 2007.

GRUPIONI, L. D. B. Imagens contraditórias e fragmentadas: Sobre o lugar dos índios nos Livros Didáticos. Revista Brasileira de Estudos Pedagógicos. Brasília, v.77, n.186, maio/ago, 1996, p. 409-437.

JAFELICE, L.C. Abordagem antropológica: educação ambiental e astronômica desde uma perspectiva intercultural. In: JAFELICE, L.C. (Org.). Astronomia, educação e cultura: abordagens transdisciplinares para os vários níveis de ensino. Natal, RN: EDUFRN - Editora da UFRN, 2010. p.213-263.

.Astronomia Cultural nos ensinos Fundamental e Médio. Revista LatinoAmericana de Educação em Astronomia, n.19, 2015, p. 57-92.

Nós e os céus: um enfoque antropológico para o ensino de astronomia. In: ATAS DO VIII ENCONTRO DE PESQUISA EM ENSINO DE FÍSICA - VIII EPEF, São Paulo, 2002.

Astronomia Cultural e Educação Intercultural. In: SIMPÓSIO NACIONAL DE EDUCAÇÃO EM ASTRONOMIA, 2011, Rio de Janeiro. Atas... São Paulo, 2011, p.1-12.

JANJACOMO, J.P.; COELHO, G.R. Saberes da mediação na sala itinerante de Astronomia Indígena. In: XVI ENCONTRO DE PESQUISA EM ENSINO DE FÍSICA, 2016, Espírito Santo. Atas... Natal, 2016.

JUNIOR, J. T. O.; KILLNER, G. I.; MERLUCCI. C. M. D. Astronomia indígena: Aspectos iniciais no Ensino de Ciência através da Interculturalidade e Insterdisciplinaridade. Em: Atas do V Simpósio Nacional de Educação em Astronomia - SNEA - Londrina, Paraná, 2018.

LACERDA, F. M. R. Astronomia Cultural em uma sequência didática: Uma discussão sobre modelos. Em: Atas do IV Simpósio Nacional de Educação em Astronomia SNEA, Goiânia, 2016. 
LIMA, F. P. Astronomia Cultural nas fontes etno-históricas: a astronomia Bororo. In: SIMPÓSIO NACIONAL DE EDUCAÇÃO EM ASTRONOMIA, 2011, Rio de Janeiro.Atas... São Paulo, 2011, p.1-15.

LIMA, F. P. et al. Astronomia Indígena: Relações Céu-Terra entre os indígenas do Brasil: Distintos céus, distintos olhares. In: MATSUURA, O. T. (Org.) História da Astronomia no Brasil. v.1. Recife: CEPE, 2014, p.89-130.

LÓPEZ, A. M. Introducción. In: BORGES, L.C. (Org.) Diferentes povos, diferentes céus e saberes nas Américas: Contribuições da astronomia cultural para a história da ciência. Rio de Janeiro: Museu de Astronomia e Ciências Afins, 2015, p. $8-15$.

LUDKE, M.; ANDRÉ, M.D.A. Pesquisa em Educação: Abordagens Qualitativas. São Paulo: EPU, 1996.

MACHADO, N.J. Educação e Autoridade. Petrópolis/RJ: Vozes, 2008.

MARTINS, R.A. Sobre o papel da história da ciência no ensino. Boletim da Sociedade Brasileira de História da Ciência. 1990, p. 3-5.

MCLAREN, P. Multiculturalismo crítico. São Paulo: Cortez, 1997.

MERLUCCI, C. M. D. et al. Astronomia Cultural nas pesquisas de ensino: um panorama da década atual (2010-2018). In: XXIII SIMPÓSIO NACIONAL DE ENSINO DE FÍSICA. Salvador - BA, 2019.

MELLO, F. C.; SOARES, J. B.; KERBER, L. O. Astronomia e educação intercultural: experiências no ensino de Astronomia e ciências em escolas indígenas. In:

SIMPÓSIO NACIONAL DE EDUCAÇÃO EM ASTRONOMIA, 2011, Rio de Janeiro. Atas...São Paulo, 2011, p.1-12.

MORAES, Roque. Análise de conteúdo. Revista Educação, Porto Alegre, v. 22, n. 37, 1999, p.7-32.

MOREIRA, A. F. B.; CANDAU, V. M. Educação escolar e cultura (s): construindo caminhos. Revista Brasileira de Educação. Rio de Janeiro, n. 23, 2003, p.156-168, mai./ago.

MOREIRA, A. F. B.; CANDAU, V. M. Indagações sobre currículo: currículo, conhecimento e cultura. Organização do documento Jeanete Beauchamp, Sandra Denise Pagel, Aricélia Ribeiro do Nascimento. - Brasília: Ministério da Educação, Secretaria de Educação Básica, 2007.

MOREIRA, A. F. B.; SILVA, T. T. Sociologia e Teoria Crítica do Currículo: uma introdução. In: MOREIRA, A. F. B.; SILVA, T. T. (Orgs.) Currículo, Cultura e Sociedade. São Paulo: Cortez, 2013, p. 7- 37. 
NASCIMENTO, M. I. M. Instituições escolares no Brasil colonial e imperial. Revista História, Sociedade e Educação no Brasil (HISTEDBR) Online, Campinas, n. 28, 2007, p. 181-203.

NETO, J. M.; FRACALANZA, H. O livro didático de Ciências: problemas e soluções. Ciência \& Educação. v.9, n.2 , 2003, p.147-157.

NICODEM, M. F. M. A inserção de Paulo Freire nos estudos culturais: O conceito de cultura na Pedagogia do Oprimido, da Esperança e da Autonomia. Revista

Eletrônica Científica Inovação e Tecnologia. Universidade Tecnológica Federal do Paraná. Paraná, v.01, n.11, 2015, p. 23-33.

NOGUEIRA, C.M.M.; NOGUEIRA, M.A. A sociologia da educação de Pierre Bourdieu: Limites e contribuições. Educação e Sociedade. Ano XXIII, n.78, 2002, p.15-36.

OLIVEIRA, É.; LEITE, C. Multiculturalismo na Educação Básica: Uma análise da Astronomia Cultural nos Livros Didáticos de Física aprovados no PNLD 2018. Em: Atas do XVII Encontro de Pesquisa em Ensino de Física - EPEF, Campos do Jordão, São Paulo, 2018.

PÉREZ GÓMEZ.A.I. A cultura escolar na sociedade neoliberal. Porto Alegre: Artes Médicas. 2001.

QUIJANO, A. Colonialidade do poder, Eurocentrismo e América Latina. In: A colonialidade do saber: eurocentrismo e ciências sociais. Perspectivas latinoamericanas. Buenos Aires: Consejo Latinoamericano de Ciencias Sociales, 2005. p.117-142.

RODRIGUES, M. A diversidade do conhecimento sobre o céu e o ensino de Astronomia: propostas didáticas e potencialidades da astronomia cultural. Dissertação - Universidade de São Paulo, Instituto de Física, Instituto de Química, Instituto de Biologia e Faculdade de Educação, São Paulo, 2015.

RODRIGUES, M.; LEITE, C. "Astronomia Cultural" em livros didáticos de Física aprovados no PNLEM 2012. In: II SIMPÓSIO NACIONAL DE EDUCAÇÃO EM ASTRONOMIA. São Paulo - SP, 2012.

RODRIGUES, M.; LEITE, C. A lei federal 11.645 e os materiais didáticos em ensino de Astronomia Cultural. In: IV SIMPÓSIO NACIONAL DE EDUCAÇÃO EM ASTRONOMIA. Goiânia - GO, 2016.

RODRIGUES, M.; LEITE, C. O tema astronomia cultural nos referenciais curriculares estaduais no Brasil. In: X ENCONTRO NACIONAL DE PESQUISA EM EDUCAÇÃO EM CIÊNCIAS. Águas de Lindóia - SP. 2015. 
RODRIGUES, M.; LEITE, C. Potencialidades do Ensino de Astronomia para uma formação pautada na diversidade cultural: Os céus dos povos indígenas no Brasil. In: Atas do III SIMPÓSIO NACIONAL DE EDUCAÇÃO EM ASTRONOMIA. Curitiba, PR. 2014.

SANTIAGO, M. C.; AKKARI, A.; MARQUES, L.P. Educação Intercultural: desafios e possibilidades. Petrópolis, RJ: Vozes, 2013.

SANTOS, B.S. Para uma nova visão da Europa: aprender com o Sul. Sociologias, Porto Alegre, ano 18, n.43, set/dez, 2016, p.24-56.

. Percursos para as epistemologias do Sul. In: SANTOS, B. S. O fim do império cognitivo: A afirmação das epistemologias do Sul. 1.ed. Belo Horizonte: Autêntica Editora, 2019, p.41- 63.

SANTOS, L. L. C. P. O processo de produção do conhecimento escolar e a Didática. In: MOREIRA, A. F. (Org.) Conhecimento educacional e formação do professor. Campinas. Papirus, 1995.

SAVIANI, D. Escola e democracia. Campinas, SP: Autores Associados, 2008.

História das Ideias Pedagógicas no Brasil. 3ed. Campinas:

Companhia Editora Nacional, 2011.

SENA, M. K.S. et al. Reflexões sobre a origem do Universo nas perspectivas ocidental e indígena - Construindo novas narrativas através de uma proposta de ensino decolonial. In: XXIII SIMPÓSIO NACIONAL DE ENSINO DE FíSICA. Salvador - BA, 2019.

SILVA, T. T. Documentos de Identidade. 3ed.; 11.reimp. Belo Horizonte: Autêntica Editora, 2019.

SIMÕES, C. C. Elementos de Astronomia nos Livros Didáticos de Física. Belo Horizonte: PUC-Minas,2009. 144 p. Dissertação (Mestrado). Programa de Pós-Graduação em Ensino de Ciências e Matemática, Pontifícia Universidade católica de Minas Gerais, Belo Horizonte, 2008.

SPINELLI, P. F. et al. Astronomy across cultures: reporting experiences on the GalileoMobile education activities in the Paiter Suruí indigenous community. In: SIMPÓSIO INTERNACIONAL DE EDUCAÇÃO EM ASTRONOMIA E ASTROBIOLOGIA (ISE2A), 2017.

TEIXEIRA, A. Educação no Brasil. São Paulo, Companhia Editora Nacional, 1969.

TELES, L. et al. Conhecimentos Astronômicos Indígenas no Ensino de Ciências: inserção da Lei 11.645/08 no ensino fundamental. In: XI ENCONTRO NACIONAL DE 
PESQUISA EM EDUCAÇÃO EM CIÊNCIAS, Florianópolis -SC. Universidade Federal de Santa Catarina, 2017.

TELLES, N. A imagem do índio no livro didático: equivocada, enganadora. In: SILVA, Aracy Lopes da (Org.). A questão indígena na sala de aula: subsídios para professores de $1^{\circ}$ e 20 graus. São Paulo: Brasiliense, 1987.

TUBINO, F. La interculturalidad crítica como proyecto ético-político. Encuentro Continental de Educadores Agustinos. Lima: Enero 2005, p.24-28.

http://www.oalagustinos.org/edudoc/LAINTERCULTURALIDADCR\%C3\%8DTICACO MOPROYECTO\%C3\%89TICO.pdf. Acesso em 07 nov. 2019

UNESCO. Declaração Universal sobre a Diversidade Cultural. 2002. Disponível em $<$ http://unesdoc.unesco.org/images/0012/001271/127160por.pdf > . Acesso em: 29 jul. 2018

WALSH,C. Interculturalidade Crítica e Pedagogia Decolonial: in-surgir, re-existir e reviver. In: CANDAU, V. M. (Org.) Educação Intercultural na América Latina: entre concepções, tensões e propostas. Rio de Janeiro: 7 Letras, 2009.

ZANATTI, A.W.; SIQUEIRA, J.F.R. Etnoastronomia: um resgate das culturas africana e indígena. In: SIMPÓSIO NACIONAL DE EDUCAÇÃO EM ASTRONOMIA, 2., 2012, São Paulo. Atas... São Paulo: Instituto de Física da Universidade de São Paulo, 2012, p.319-324. 


\section{LIVROS DIDÁTICOS DE CIÊNCIAS ANALISADOS}

BARROS, C.; PAULINO, W. Ciências, 6º ano. 6.ed. São Paulo: Ática, 2015.

BARROS, C.; PAULINO, W. Ciências, $7^{\circ}$ ano. 6.ed. São Paulo: Ática, 2015.

BARROS, C.; PAULINO, W. Ciências, 8o ano. 6.ed. São Paulo: Ática, 2015.

BARROS, C.; PAULINO, W. Ciências, 9º ano. 6.ed. São Paulo: Ática, 2015.

CANTO, E. L. Ciências Naturais: Aprendendo com o Cotidiano. 6ํano. 5. ed. São Paulo: Moderna, 2015.

CANTO, E. L. Ciências Naturais: Aprendendo com o Cotidiano. $7^{\circ}$ ano. 5. ed. São Paulo: Moderna, 2015.

CANTO, E. L. Ciências Naturais: Aprendendo com o Cotidiano. $8^{\circ}$ ano. 5. ed. São Paulo: Moderna, 2015.

CANTO, E. L. Ciências Naturais: Aprendendo com o Cotidiano. 9ํano. 5. ed. São Paulo: Moderna, 2015.

CATANI, A.; AGUILAR, J. B.; ROSELINO, F.T. Para viver juntos: Ciências da Natureza, 6º ano. 4.ed. São Paulo: Edições SM, 2015.

AGUILAR, J. B. Para viver juntos: Ciências da Natureza, $7^{\circ}$ ano. 4.ed. São Paulo: Edições SM, 2015.

AGUILAR, J. B.; SIGNORINI, P. Para viver juntos: Ciências da Natureza, $8^{\circ}$ ano. 4.ed. São Paulo: Edições SM, 2015.

NERY, A.L.P.; KILLNER, G. I. Para viver juntos: Ciências da Natureza, 9ำ ano. 4.ed. São Paulo: Edições SM, 2015.

EDIÇÕES SM (Org.). Universos: ciências da natureza, 6ํano. 3. ed. São Paulo: SM, 2015.

EDITORA DO BRASIL (Org.). Tempo de Ciências, 6ํano. 2.ed. São Paulo: Editora do Brasil, 2015.

EDITORA DO BRASIL (Org.). Tempo de Ciências, $7^{\circ}$ ano. 2.ed. São Paulo: Editora do Brasil, 2015. 
EDITORA DO BRASIL (Org.). Tempo de Ciências, 8ํano. 2.ed. São Paulo: Editora do Brasil, 2015.

EDITORA DO BRASIL (Org.). Tempo de Ciências, 9ํano. 2.ed. São Paulo: Editora do Brasil, 2015.

EDITORA MODERNA (Org.). Projeto Araribá, 6a ano, 4.ed. São Paulo: Editora Moderna, 2014.

EDITORA MODERNA (Org.). Projeto Araribá, 7ํano, 4.ed. São Paulo: Editora Moderna, 2014.

EDITORA MODERNA (Org.). Projeto Araribá, 8a ano, 4.ed. São Paulo: Editora Moderna, 2014.

EDITORA MODERNA (Org.). Projeto Araribá, 9a ano, 4.ed. São Paulo: Editora Moderna, 2014.

FUKUI, A. Universos: Ciências da Natureza, 9ํano, 3 ed. São Paulo: SM, 2015.

GEWANDSZNAJDER, F. Projeto Teláris, 6ํano, 2.ed. São Paulo: Ática, 2016.

GEWANDSZNAJDER, F. Projeto Teláris, 7ํano, 2.ed. São Paulo: Ática, 2016.

GEWANDSZNAJDER, F. Projeto Teláris, 8ํano, 2.ed. São Paulo: Ática, 2016.

GEWANDSZNAJDER, F. Projeto Teláris, 9aa, 2.ed. São Paulo: Ática, 2016.

GOWDAK, D. O.; MARTINS, E. L. Ciências Novo Pensar, 6ํano. 2 ed. São Paulo: FTD, 2015

GOWDAK, D. O.; MARTINS, E. L. Ciências Novo Pensar, $7^{\circ}$ ano. 2 ed. São Paulo: FTD, 2015

GOWDAK, D. O.; MARTINS, E. L. Ciências Novo Pensar, 8ano. 2 ed. São Paulo: FTD, 2015

GOWDAK, D. O.; MARTINS, E. L. Ciências Novo Pensar, 9a ano. 2 ed. São Paulo: FTD, 2015

OLIVEIRA, M. M. A. Universos: ciências da natureza, $7^{\circ}$ ano. 3. ed. São Paulo: SM, 2015. 
LOLI, D.; SANTOS, F. S.; OLIVEIRA, M. M. A. Universos: ciências da natureza, $8^{\circ}$ ano. 3.ed. São Paulo: SM, 2015.

LOPES, S. Investigar e conhecer: Ciências da natureza, 6ํano. 1. ed. São Paulo: Saraiva, 2015.

LOPES, S. Investigar e conhecer: Ciências da natureza, $7^{0}$ ano. 1. ed. São Paulo: Saraiva, 2015.

LOPES, S. Investigar e conhecer: Ciências da natureza, $8^{\circ}$ ano. 1. ed. São Paulo: Saraiva, 2015.

LOPES, S. Investigar e conhecer: Ciências da natureza, 9a ano. 1. ed. São Paulo: Saraiva, 2015.

TRIVELLATO JÚNIOR, J. et al. Ciências, 6ํano. 1ed. São Paulo: Quinteto Editorial, 2015

TRIVELLATO JÚNIOR, J. et al. Ciências, $7^{\circ}$ ano. 1ed. São Paulo: Quinteto Editorial, 2015

TRIVELLATO JÚNIOR, J. et al. Ciências, $8^{\circ}$ ano. 1ed. São Paulo: Quinteto Editorial, 2015

TRIVELLATO JÚNIOR, J. et al. Ciências, 9ํano. 1ed. São Paulo: Quinteto Editorial, 2015

USBERCO, J. et al. Companhia das Ciências, 6o ano. 4 ed. São Paulo: Saraiva, 2015

USBERCO, J. et al. Companhia das Ciências, $7^{0}$ ano. 4 ed. São Paulo: Saraiva, 2015

USBERCO, J. et al. Companhia das Ciências, $8^{\circ}$ ano. 4 ed. São Paulo: Saraiva, 2015

USBERCO, J. et al. Companhia das Ciências, 9a ano. 4 ed. São Paulo: Saraiva, 2015

PEREIRA, A. M.; SANTANA, M.; WALDHELM, M. Projeto Apoema. $6^{\circ}$ ano. 2.ed. São Paulo, 2015.

PEREIRA, A. M.; SANTANA, M.; WALDHELM, M. Projeto Apoema. $7^{\circ}$ ano. 2.ed. São Paulo, 2015. 
PEREIRA, A. M.; SANTANA, M.; WALDHELM, M. Projeto Apoema. $8^{\circ}$ ano. 2.ed. São Paulo, 2015.

BEMFEITO, A. P.; PINTO, C. E. Projeto Apoema. 9ª ano. 2.ed. São Paulo, 2015. 


\section{LIVROS DIDÁTICOS DE FÍSICA ANALISADOS}

BARRETO, B.; XAVIER, C.; Física aula por aula, $1^{\circ}$ ano, 3. ed. São Paulo: FTD, 2016

BARRETO, B.; XAVIER, C.; Física aula por aula, 2ํano, 3. ed. São Paulo: FTD, 2016

BARRETO, B.; XAVIER, C.; Física aula por aula, 3ำ ano, 3. ed. São Paulo: FTD, 2016

BONJORNO; CASEMIRO et al., Física, 1ํano, 3. ed. São Paulo: FTD, 2016.

BONJORNO; CASEMIRO et al., Física, 2º ano, 3. ed. São Paulo: FTD, 2016.

BONJORNO; CASEMIRO et al., Física, 3ํano, 3. ed. São Paulo: FTD, 2016.

GASPAR, A. Compreendendo a Física, 1ํano, 3. ed. São Paulo: Ática, 2016

GASPAR, A. Compreendendo a Física, 2º ano, 3. ed. São Paulo: Ática, 2016

GASPAR, A. Compreendendo a Física, 3ํano, 3. ed. São Paulo: Ática, 2016

GUIMARÃES, O.; PIQUEIRA, J.R.; CARRON, W. Física. 1ำ ano, 2.ed. São Paulo: Ática (Somos Educação), 2016.

GUIMARÃES, O.; PIQUEIRA, J.R.; CARRON, W. Física. $2^{\circ}$ ano, 2.ed. São Paulo: Ática (Somos Educação), 2016.

GUIMARÃES, O.; PIQUEIRA, J.R.; CARRON, W. Física. 3ำano, 2.ed. São Paulo: Ática (Somos Educação), 2016. 
HELOU, R.; BISCOULA, G.; VILLAS BÔAS, N. Física para o Ensino Médio. 3. ed. Volume 1. São Paulo: Saraiva (Somos Educação), 2016.

HELOU, R.; BISCOULA, G.; VILLAS BÔAS, N. Física para o Ensino Médio. 3. ed. Volume 1. São Paulo: Saraiva (Somos Educação), 2016.

HELOU, R.; BISCOULA, G.; VILLAS BÔAS, N. Física para o Ensino Médio. 3. ed. Volume 1. São Paulo: Saraiva (Somos Educação), 2016.

MARTINI. G.; SPINELLI, W.; REIS, H.C.; SANT'ANNA, B. Conexões com a Física. 3.ed. Volume 1. São Paulo: Moderna, 2016.

MARTINI. G.; SPINELLI, W.; REIS, H.C.; SANT'ANNA, B. Conexões com a Física. 3.ed. Volume 2. São Paulo: Moderna, 2016.

MARTINI. G.; SPINELLI, W.; REIS, H.C.; SANT'ANNA, B. Conexões com a Física. 3.ed. Volume 3. São Paulo: Moderna, 2016.

MÁXIMO, A.; ALVARENGA, B.; GUIMARÃES, C. Física: Contexto \& Aplicações, $1^{\circ}$ ano, 2. ed. São Paulo: Editora Scipione, 2016.

MÁXIMO, A.; ALVARENGA, B.; GUIMARÃES, C. Física: Contexto \& Aplicações, 2o ano, 2. ed. São Paulo: Editora Scipione, 2016.

MÁXIMO, A.; ALVARENGA, B.; GUIMARÃES, C. Física: Contexto \& Aplicações, 3o ano, 2. ed. São Paulo: Editora Scipione, 2016.

PIETROCOLA, M.; POGIBIN, A.; ANDRADE, R.; ROMERO, T.R. Física em Contextos. 1. ed. Volume 1. São Paulo: Editora do Brasil, 2016

PIETROCOLA, M.; POGIBIN, A.; ANDRADE, R.; ROMERO, T.R. Física em Contextos. 1. ed. Volume 2. São Paulo: Editora do Brasil, 2016 
PIETROCOLA, M.; POGIBIN, A.; ANDRADE, R.; ROMERO, T.R. Física em Contextos. 1 ed. Volume 3. São Paulo: Editora do Brasil, 2016

TORRES, C.M. FERRARO, N. G. et al., Física - Ciência e Tecnologia, 1ํano, 4. ed. São Paulo: Moderna, 2016.

TORRES, C.M. FERRARO, N. G. et al., Física - Ciência e Tecnologia, ํㅡo ano, 4. ed. São Paulo: Moderna, 2016.

TORRES, C.M. FERRARO, N. G. et al., Física - Ciência e Tecnologia, $3^{\circ}$ ano, 4. ed. São Paulo: Moderna, 2016.

TOSCANO, A. G.; TOSCANO, C. Física- Interação e Tecnologia. 2. ed. Volume 1. São Paulo: Leya, 2016.

TOSCANO, A. G.; TOSCANO, C. Física- Interação e Tecnologia. 2. ed. Volume 2. São Paulo: Leya, 2016.

TOSCANO, A. G.; TOSCANO, C. Física- Interação e Tecnologia. 2. ed. Volume 3. São Paulo: Leya, 2016.

VÁLIO, A.B.M.; FUKUI, A.; FERDINIAN, B.; OLIVEIRA, G.A.; MOLINA, M.M. Ser Protagonista - Física. $1^{\circ}$ ano. 3. ed. São Paulo: Edições SM, 2016.

VÁLIO, A.B.M.; FUKUI, A.; FERDINIAN, B.; OLIVEIRA, G.A.; MOLINA, M.M. Ser Protagonista - Física. $2^{\circ}$ ano. 3. ed. São Paulo: Edições SM, 2016.

VÁLIO, A.B.M.; FUKUI, A.; FERDINIAN, B.; OLIVEIRA, G.A.; MOLINA, M.M. Ser Protagonista - Física. 3ำ ano. 3. ed. São Paulo: Edições SM, 2016.

YAMAMOTO, K.; FUKE, L.F. Física para o Ensino Médio. 4ª ed. Volume 1. São Paulo. Saraiva, 2016. 
YAMAMOTO, K.; FUKE, L.F. Física para o Ensino Médio. 4 ${ }^{a}$ ed. Volume 2. São Paulo. Saraiva, 2016.

YAMAMOTO, K.; FUKE, L.F. Física para o Ensino Médio. 4ª ed. Volume 3. São Paulo. Saraiva, 2016. 


\section{ANEXOS}

Anexo 1 - Exemplos de como a temática da astronomia aparece ao final dos capítulos.

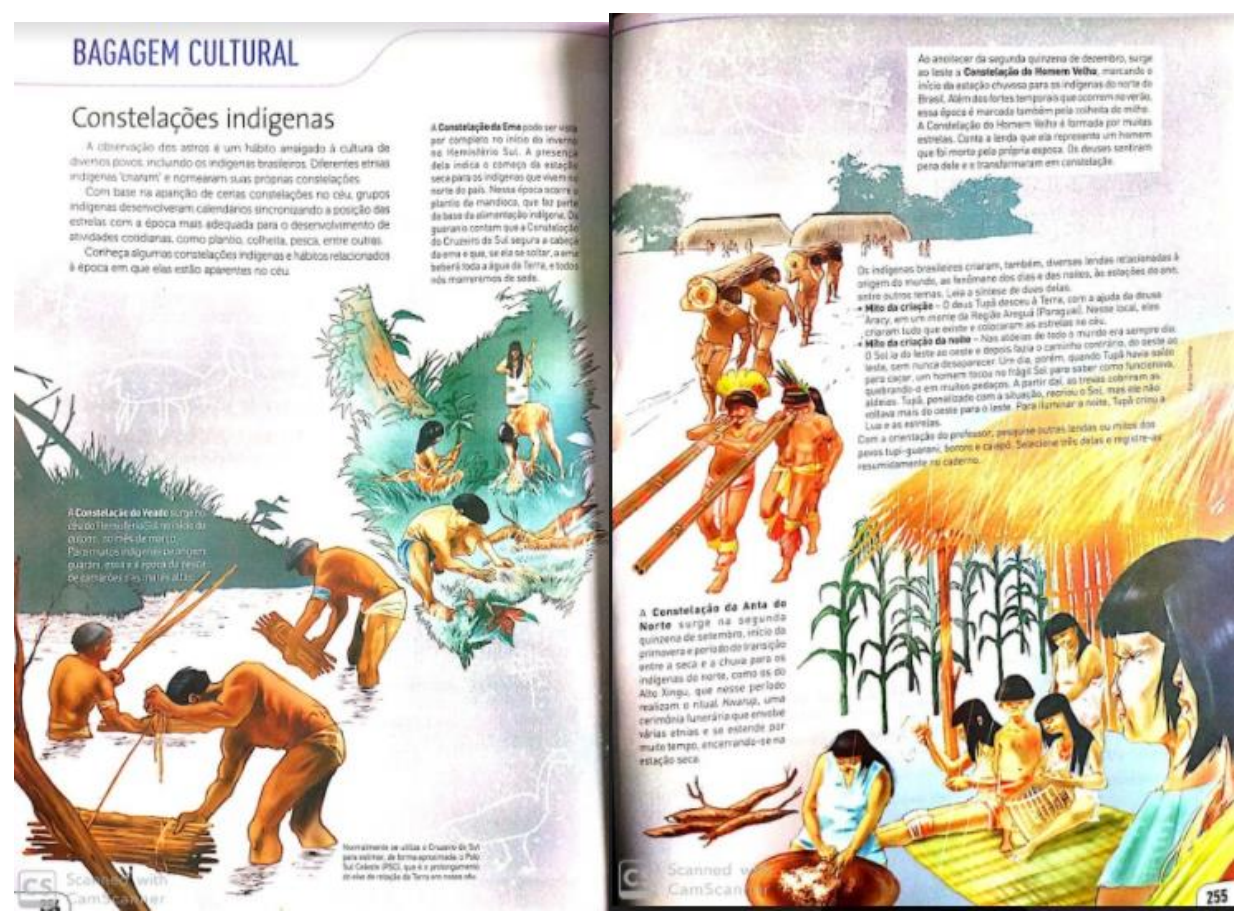

Ciências - Coleção 12 : PEREIRA, A. M.; SANTANA, M.; WALDHELM, M. Projeto Apoema. 6ํano. 2.ed. São Paulo, 2015.

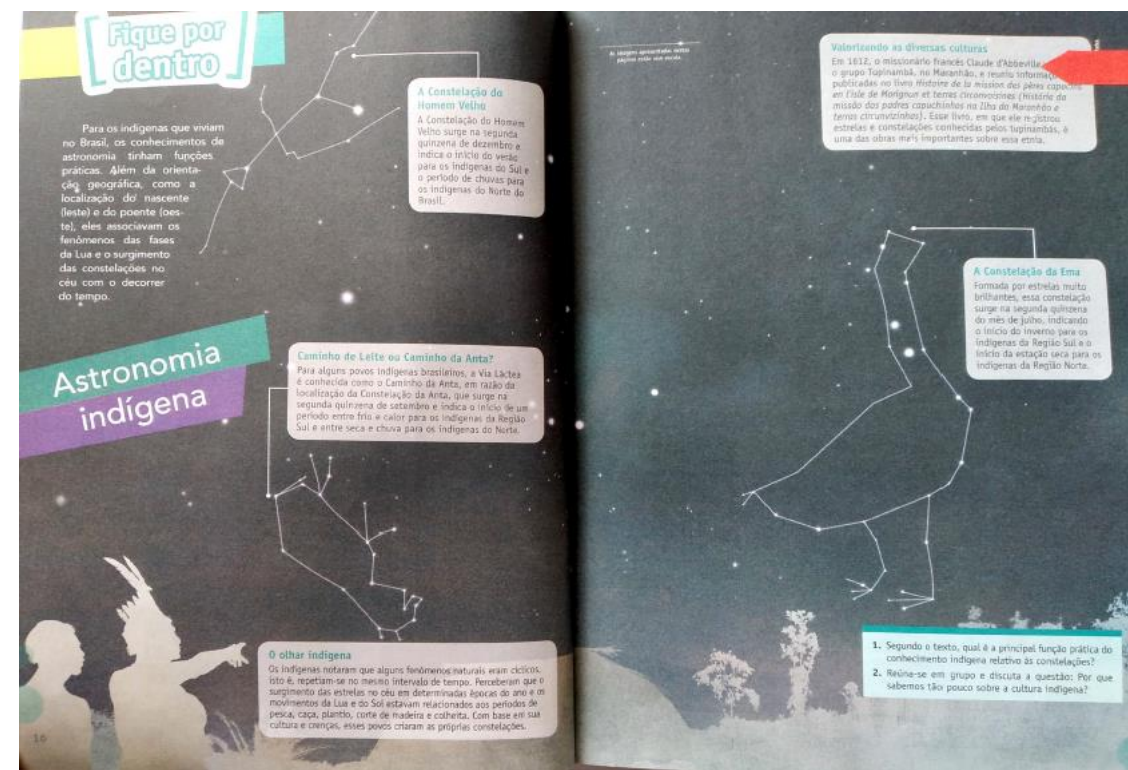

Ciências - Coleção 09 : EDITORA DO BRASIL (Org.). Tempo de Ciências, $6^{\circ}$ ano. 2.ed. São Paulo: Editora do Brasil, 2015. 


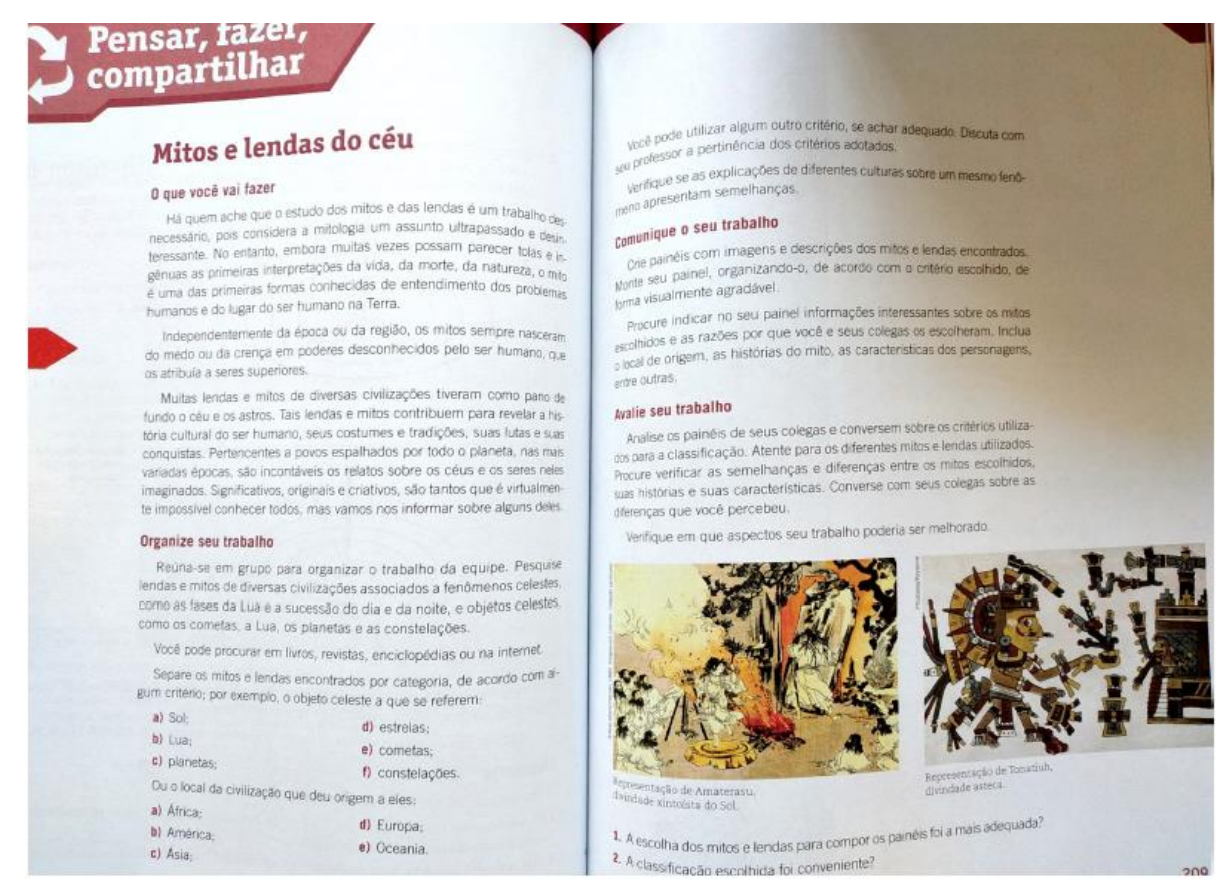

Ciências - Coleção 05: TRIVELLATO JÚNIOR, J. et al. Ciências, 6ํano. 1ed. São Paulo: Quinteto Editorial, 2015. 
Anexo 02 - Texto encontrado na coleção 07 de Ciências, que retrata os conhecimentos astronômicos indígenas.

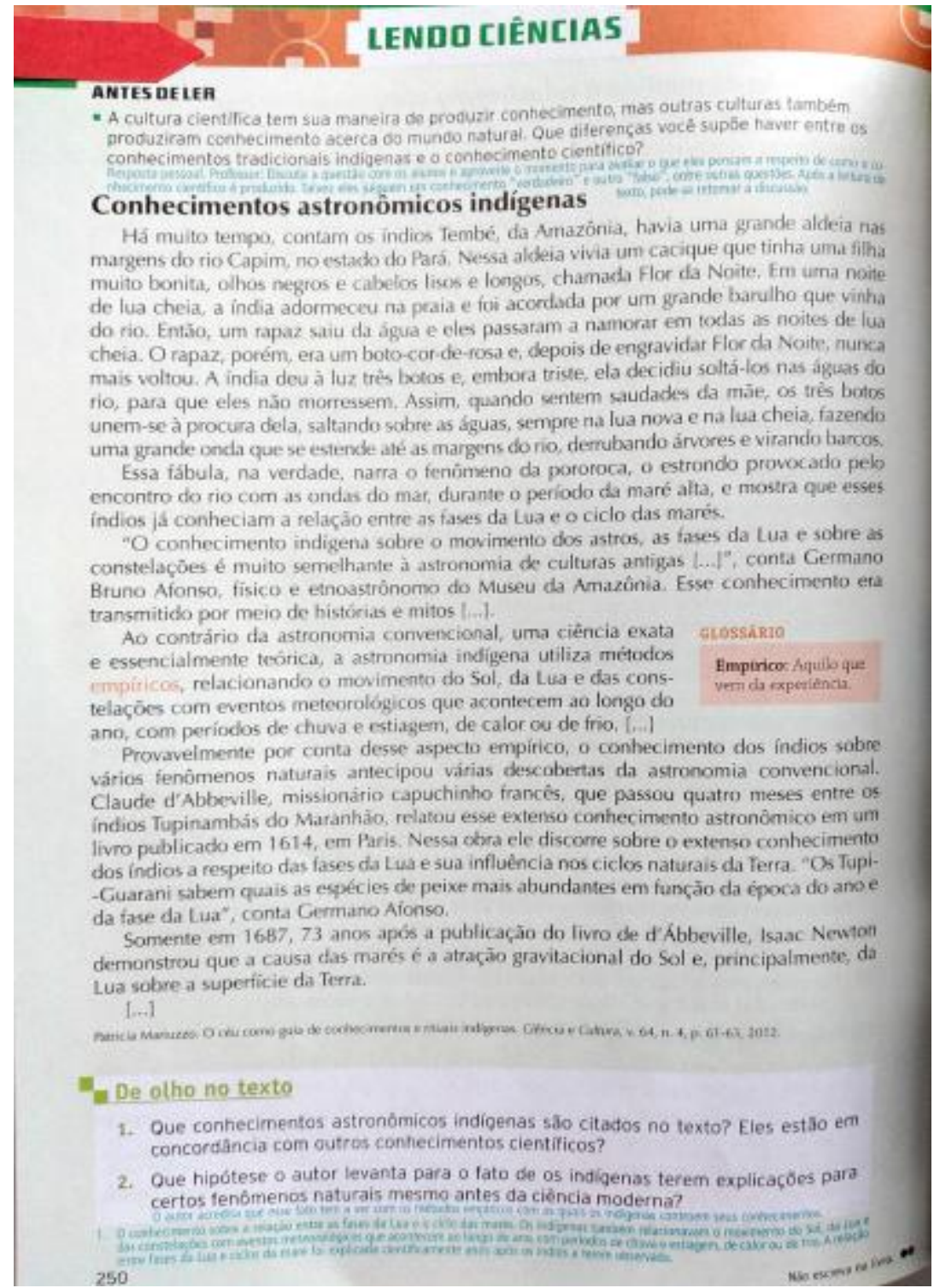


Anexo 03: Exemplos de elementos dos livros de Ciências inseridos na subcategoria "Outros"

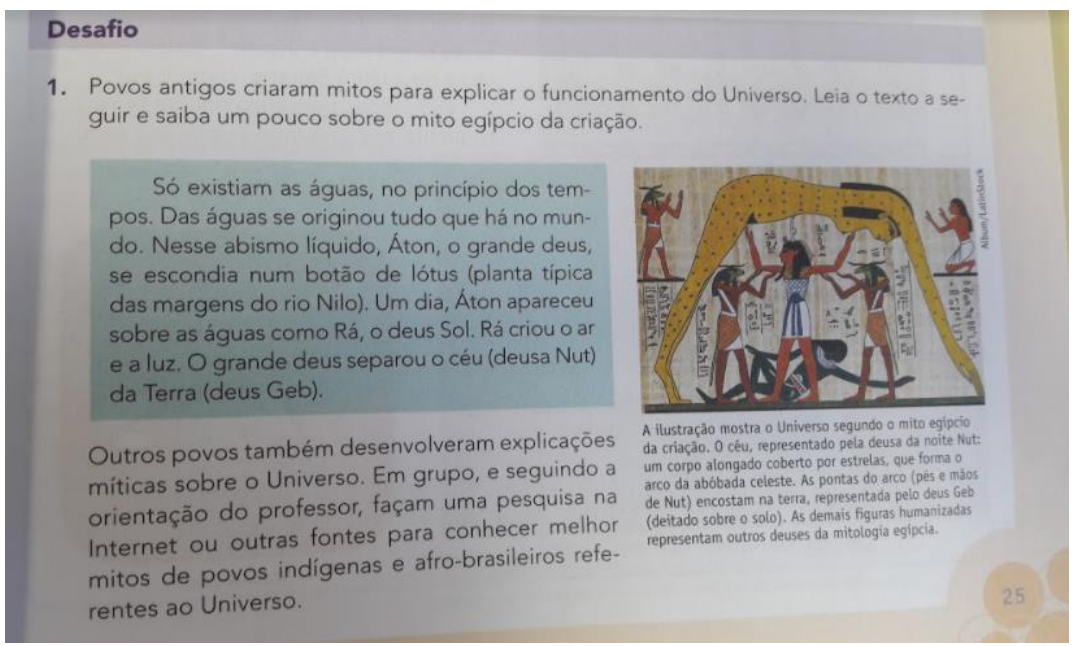

Ciências - Coleção 09 : EDITORA DO BRASIL (Org.). Tempo de Ciências, 6ํㅡ. 2.ed. São Paulo: Editora do Brasil, 2015

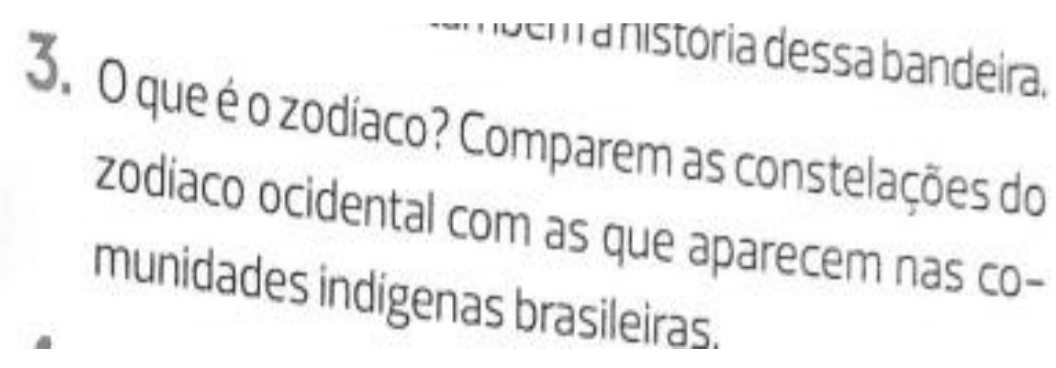

Ciências - Coleção 10: GEWANDSZNAJDER, F. Projeto Teláris, 6ำ ano, 2.ed. São Paulo: Ática, 2016.

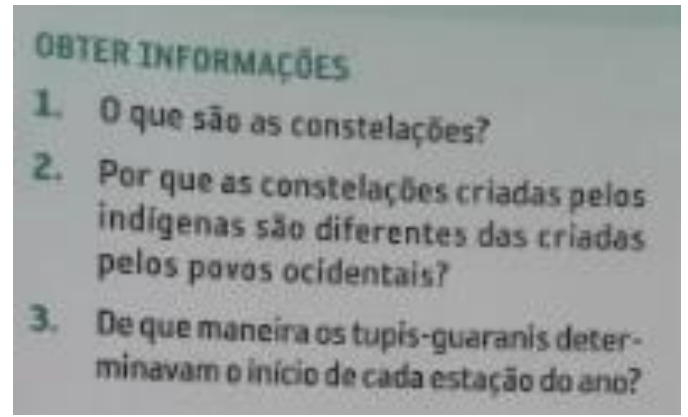

Ciências - Coleção 11: EDITORA MODERNA (Org.). Projeto Araribá, 6oano, 4.ed. São Paulo: Editora Moderna, 2014. 


\section{Anexo 04 - Texto de orientação da coleção 02 de ciências, presente no Manual do Professor}

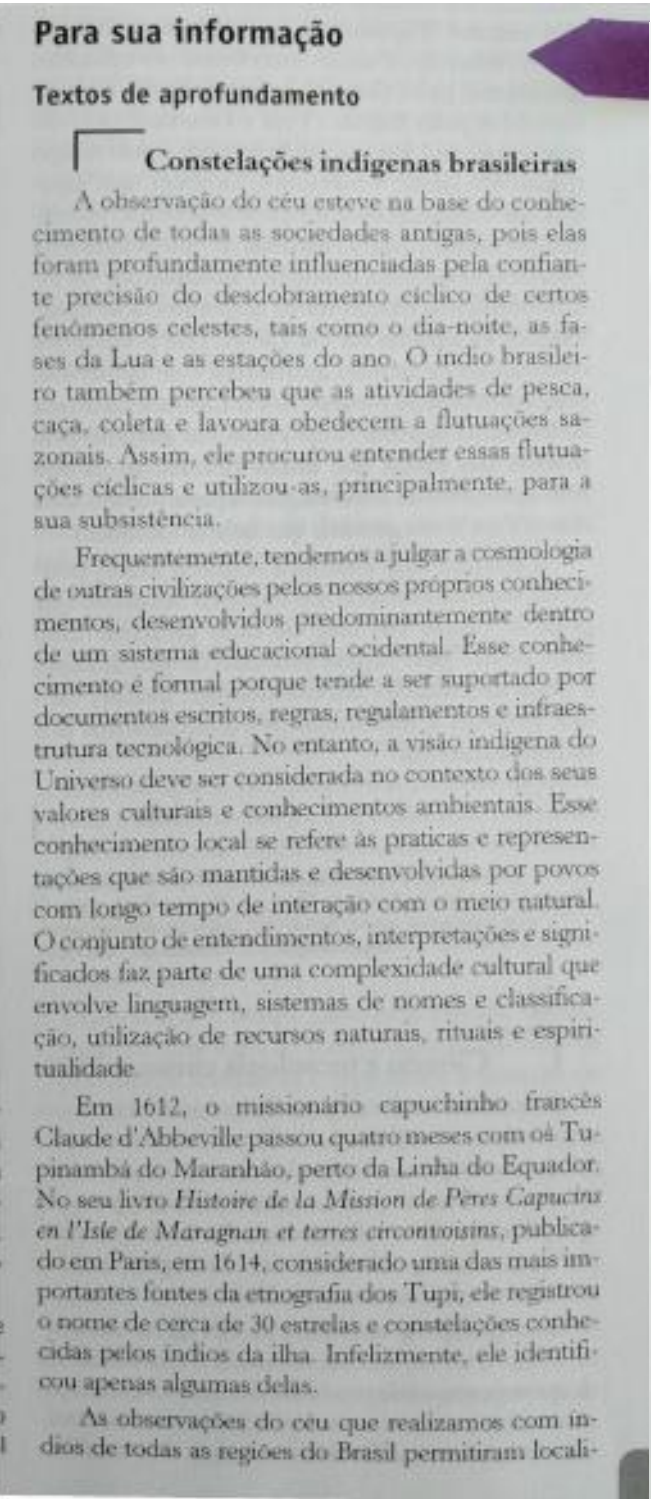

zar in maioria das constelaçoes. Tupinambá, apenas relatadas por d'Abbeville e de diversas outras etnias indigeras brasileiras.

Um dos motivos que nos incentivou a realizar este trabalho de resgate da astronomia indigeni brasileira foi verificar que o sistema astronômico dos extintos Tupinambá do Maranhào, descrito por d'Abbeville, é muito semelhante ao utilizado. atualmente, pelos Guarani do Sul do Brasil, embora separados pelas linguas (Tupi e Guarani), pelo espaço (mais de $2500 \mathrm{~km}$, em linha reta) e pelo tempo (quase 400 anos). Verificamos, tambem, que algumas das constelaçóes dos indios brasileiros, utilizadas no cotidiano, são as mesmas de outros indios da América do Sul e dos aborigines australianos. Os indios brasileiros davam maior importancia as constelacoóes localizadas na Via Lactea, que podiam ser constituidas de estrelas individuais e de nebulosas. principalmente as escuras. A Via Lactea é chamada de Caminho da Anta (Tapi'i rapé, em guarani) pela maioria das etnias dos indios brasileiros, devido principalmente as constelaçóes representando umi Anta (Tapi'i, em guarani) que nela se localizam.

A comunidade cientifica conhece muito pouco do sistema astronómico indigena brasileiro que pode se perder em uma cu duas geraçoes. Esse risco ocorre pelo rapido processo de globalizaçá e pelas dificuldades em documentar, avaliar, validar, proteger e disseminar os conhecimentos dos indios brasileiros.

[...

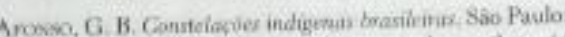
Obervationos Virtuais. Fundaçä Vitac, \& d. Disponivel em: Shetp:? www. cienciamao. usp br/dadoa/tne/ constelwoecindigenasbra

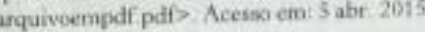

Ciências - Coleção 02 : EDIÇÕES SM (Org.). Universos: ciências da natureza, 60 ano. 3. ed. São Paulo: SM, 2015. 